\title{
38. SEDIMENTOLOGY SYNTHESIS: LITHOLOGY, CHEMISTRY AND PHYSICAL PROPERTIES OF SEDIMENTS IN THE NORTHWESTERN PACIFIC OCEAN
}

\author{
A. C. Pimm, Scripps Institution of Oceanography, La Jolla, California \\ R. E. Garrison, University of California, Santa Cruz, California \\ and \\ R. E. Boyce, Scripps Institution of Oceanography, La Jolla, California
}

\section{CONTENTS}

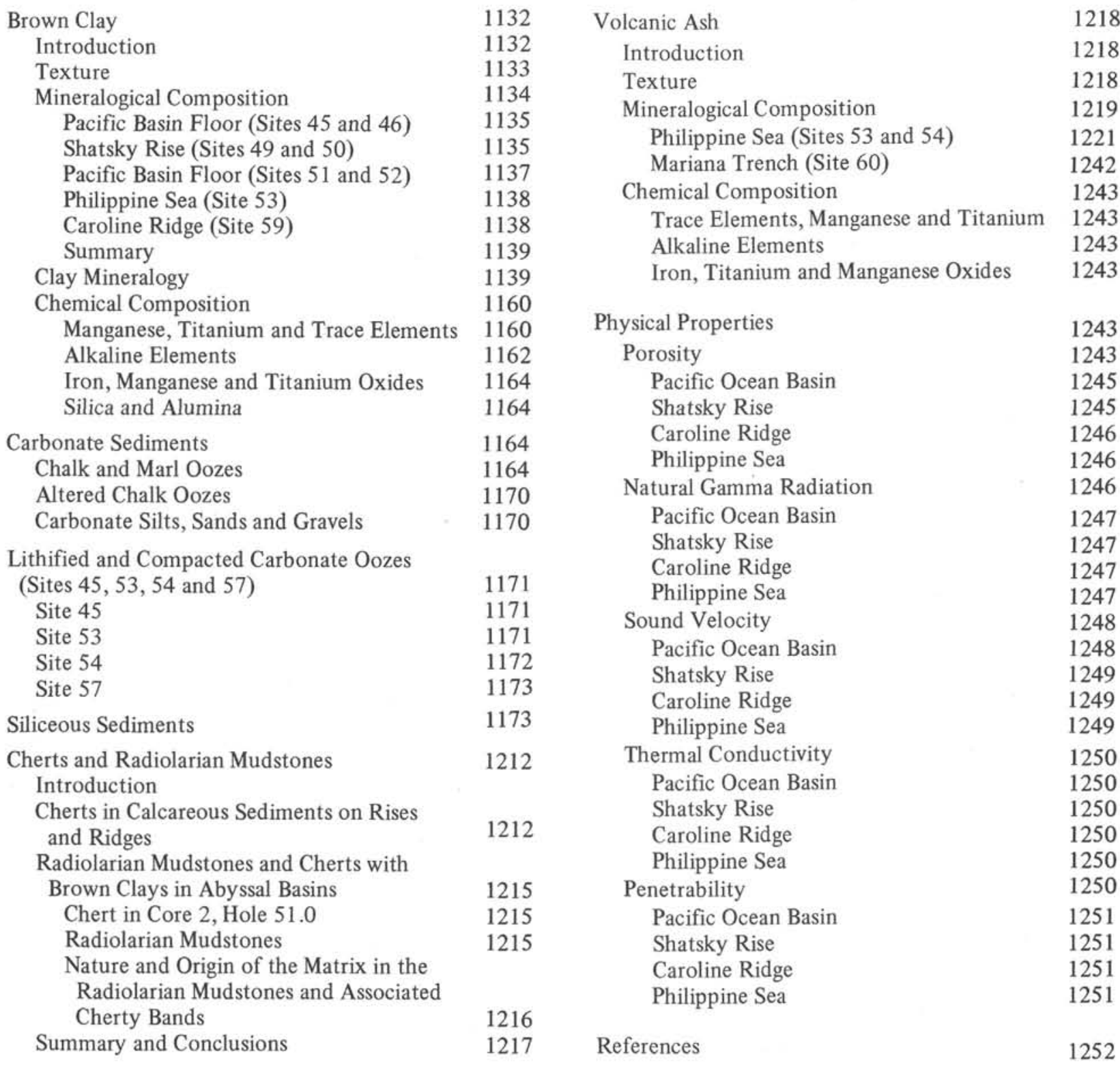




\section{BROWN CLAY}

(A. C.P.)

\section{Introduction}

Brown clay was recovered from Sites 45, 46, 49, 50, $51,52,53$ and 59 (Figure 1). Of these sites, four (45, 51,52 and 59) are at present in water depths exceeding 5000 meters with brown clay ranging in age from Recent to Upper Cretaceous. Two of these sites (45 and 51), however, contain carbonates in the Middle to Lower Cretaceous. Sites 50 and 53 are in present water depths ranging from 4300 to 4600 meters and only contain brown clay in the Upper Tertiary. Site 49 has some interbedded marl ooze with the brown clay in the Pleistocene; the present water depth here is 4282 meters and, therefore, is probably close to the calcium carbonate compensation.depth. The distribution of the brown clay then is closely related to water depth (Figure 2) and on the evidence of drilling during Leg 6 occurs everywhere in the West Pacific in water deeper than about 4000 to 4200 meters and in the Philippine Sea in water deeper than 4500 meters. Other workers (Peterson, 1966; Ruddiman and Heezen, 1967; and Berger, 1967) have shown that the carbonate compensation depth in the Pacific Ocean's lower and middle latitudes lie today at about 4000 meters.
In the account which follows the brown clay is considered to have been derived from two main sources: a local volcanic source in the Pacific floor and a far removed continental source. The mechanisms for transporting continentally derived material so far out into the Pacific deeps are mainly wind currents (eolian) and bottom transport (nepheloid layer). It is difficult to estimate the relative roles played by each transporting mechanism because of the uniformity and fine grain size of clay. Also work on the nepheloid layer is still in its infancy and sedimentologists are unable to determine at present how important a role it plays in bottom transport. Rex and Goldberg (1958) estimated that in pelagic sediments with 20 per cent quartz, around half of the solid phase is of eolian origin. In this account all material of continental origin has been ascribed to an eolian source although it is fully realized that this may only be one, albeit the most important, of several transporting mechanisms.

The main minerals present in the brown clay are quartz, plagioclase feldspar, illite and kaolinite. In some of the brown clay montmorillonite, phillipsite and volcanic glass are also major constituents. Small quantities of a variety of heavy minerals occur in these clays; the most ubiquitous being pyroxene, amphibole and iron oxides.

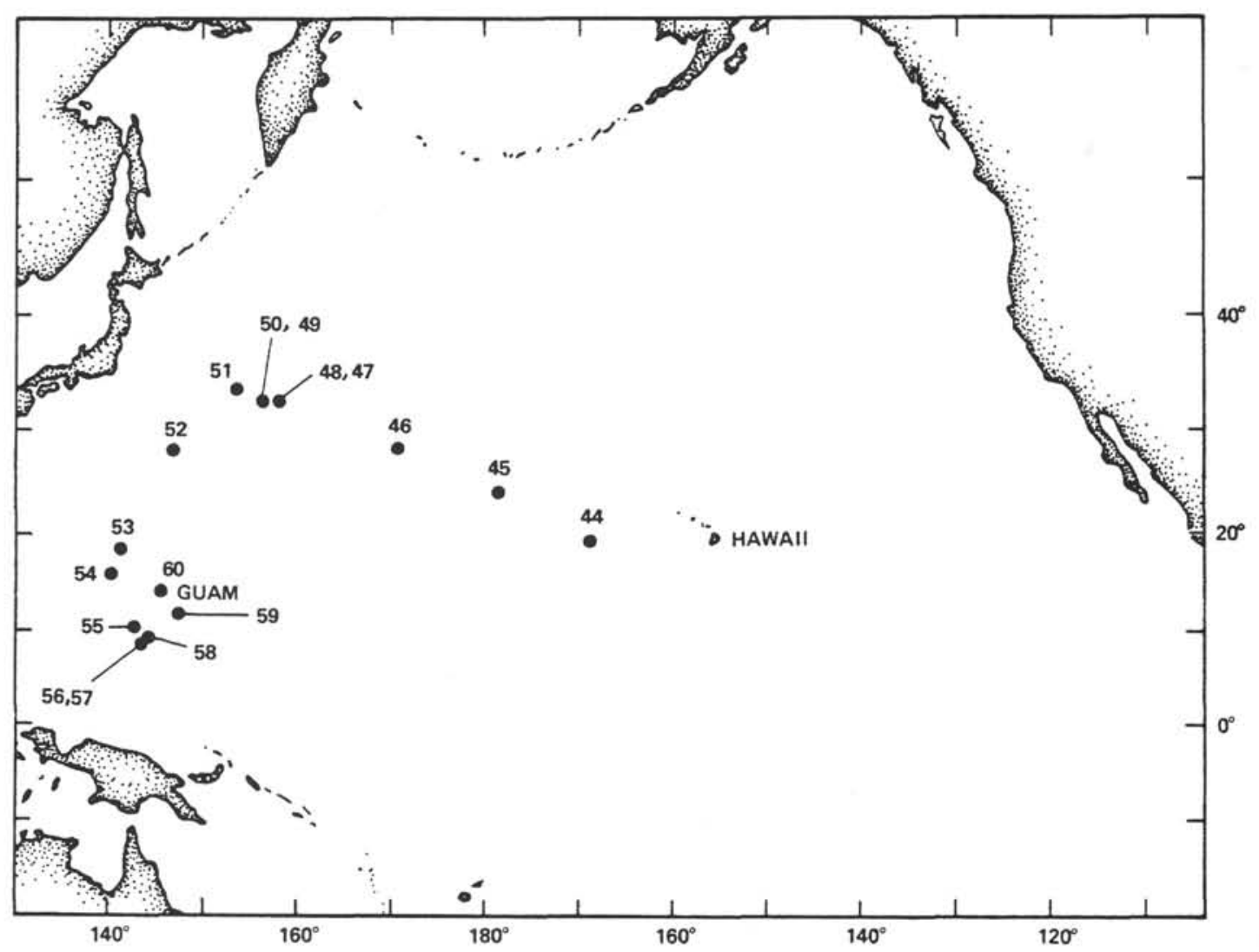

Figure 1. Location of sites drilled on Leg 6. 


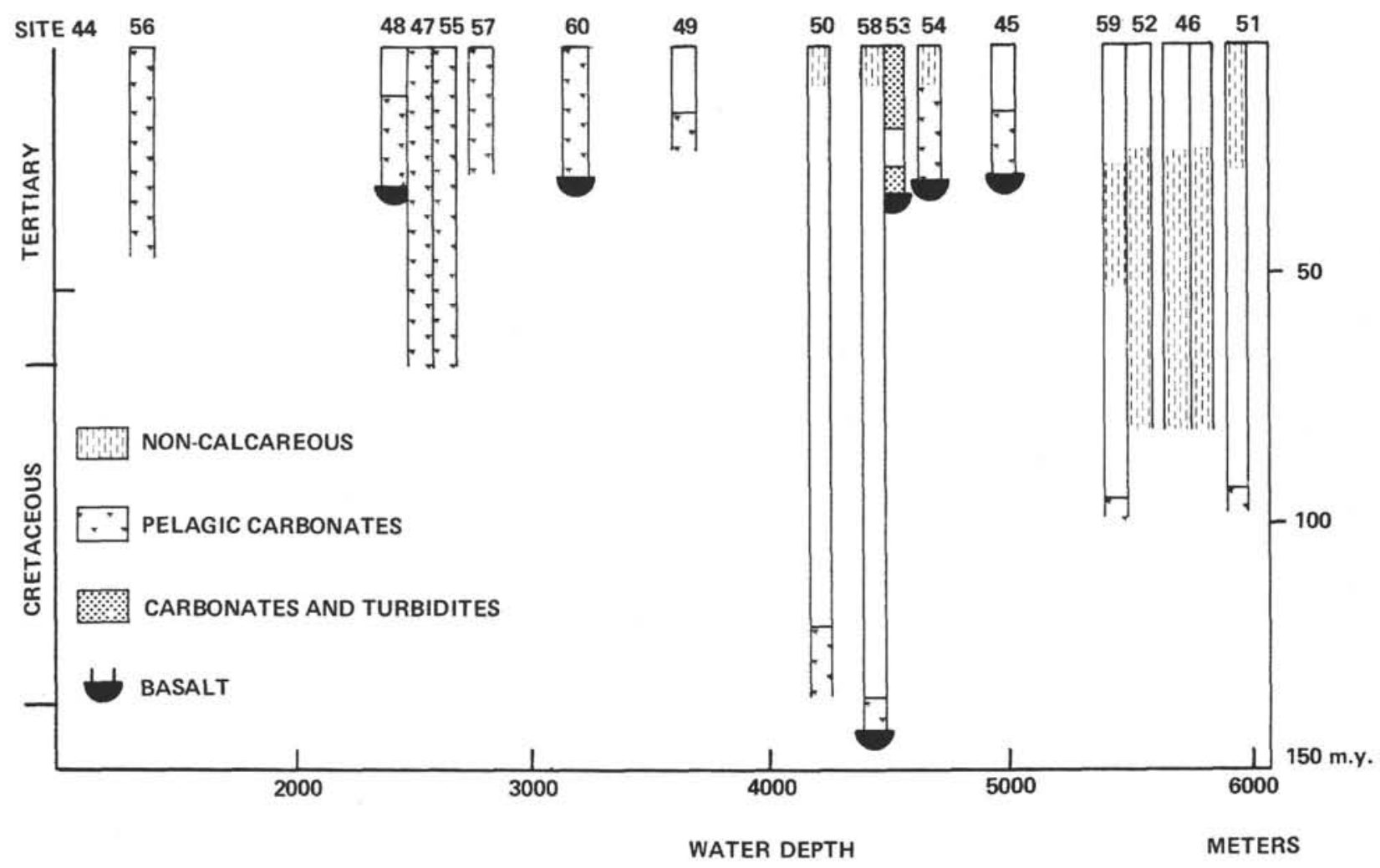

Figure 2. Lithology of sediments plotted against depth of sea.

The biogenic portion of the brown clay predominantly comprises Radiolaria, with small amounts of sponge spicules, diatoms, and fish debris. Judging from both the grain size analyses and smear slide observation the biogenic constituents only make up a very small proportion of the clay.

The clay is usually brown to dark brown in color, but often has yellowish or grayish hues where the volcanogenic component becomes important.

None of the clay sequences recovered have yielded sufficient fossil control to allow an accurate calculation of the sedimentation rates. In all cases, coring of the brown clay was discontinuous and, therefore, only average rates between coring runs were available. Low rates of sedimentation averaging 1 to 5 meters per million years are indicated for most of the brown clays recovered on Leg 6. This compares with a figure of 0.8 to 2.0 meters per million years for "red" clay sedimentation rates based on absolute dating of ash layers in the North Pacific (Nikovich et al., 1966). An exception to the low rates was seen at Site 51 where the sedimentation rates in the Pliocene were 16 meters per million years and in the Quaternary 25 meters per million years. The unusually high rates of sedimentation here may be due partly to an abundance of volcanic ash mixed in with the brown clay, but also possibly to drilling disturbance with consequent downhole slumping.

\section{Texture}

Grain size analysis results and description of the coarse fractions are given in Chapter 22. The brown clays contain, in most cases, more than 80 per cent of material in the clay-size range. In a few places silty clays occur, this being due mainly to an admixture of volcanic glass of silt size.

The median diameter of the clay particles ranges from 0.001 (Sites 45, 59) to 0.004 millimeter (Sites 49, 50, 52,53 ) with intermediate values of 0.002 millimeter in Site 51 and 0.003 millimeter in Site 46.

Cumulative curves (Chapter 27) show that the clay is well sorted $(\mathrm{So}=2.5)$; in places a predominance of fine material gives a slight negative skewness to the curve.

The brown clay usually has a uniform texture and does not reveal any visual structure in the split cores. In a few cases, structures were seen and these are described below. In some cases, it is hard to determine whether the structures are original features or are secondary features caused by drilling deformation. 
Definite evidence for burrowing was seen in 45.1-1-2 (Chapter 3) where dark yellowish-brown ash from above fills burrow mottles in moderate brown clay below. Elsewhere in Hole 45.1 more compact and drier yellowish-brown ash occurs as blebs and larger irregular mottles, up to 15 centimeters across, throughout softer moderate brown clays. Presumably, such a feature is caused by the breaking up of more coherent ash layers by drilling. In Hole 46.0 fragments of soft light reddishbrown and whitish ash occur in very soft brown clay; again, this is interpreted as a breaking up of interbedded ash layers.

In Hole 49.0-1-1 the clay is heavily mottled in brown, pale brown and light yellowish-brown colors. This is interpreted as being caused by burrowing organisms, because throughout this same section horizontal boundaries between differing lithologies are still visible.

In 50.1-1-1 (Plate 1, Figures 1,2) a zone 45 centimeters thick comprises burrowed mottles of yellowish-brown and dark yellowish-brown calcareous clay in a matrix of brown clay which contains considerably less calcareous material. Beneath this mottled zone are interbeds of the above two sediment types. The interbeds range from 3 to 20 centimeters thick and are unaffected by mottling of any kind. In the same core from Section 2 down, the mottling and flowage seen in the clay is quite obviously due to drilling disturbance (Plate 1, Figure 3).

Another unusual feature was seen in Sections 1 through 5 of Core 1 in Hole 51.0. This is a distinctive breccia comprising coherent rounded and elongate fragments of zeolite clay and diatomaceous ooze with volcanic glass in a very watery brown clay matrix (Plate 1, Figure 4). The fragments are densely packed and average about 3 to 4 centimeters in length for Sections 1 and 2, but 10 to 15 centimeters in Section 3. The fragments are nearly always 1 to 2 centimeters thick and consequently this thickness may represent the original size of more coherent interbeds which were broken up by drilling. One puzzling feature, however, is that if these fragments were broken away from beds of more coherent sediment, then why are their margins so smoothly rounded?

One other feature seen in the brown clays from Leg 6 is that of clay with apparently the same lithology forming distinctively softer and harder bands. For example, in 52.0-2-3 brown clay forms beds of alternately softer material with a smooth wet surface and harder dry material which has a rough surface in the split core (see core photograph in Chapter 10). This apparent contrast in consolidation was confirmed by the penetrometer values. The softer material in this section had a penetrometer value of $134 \times 10^{-1}$ millimeter in contrast to the harder material which had values of 38 and $60 \times 10^{-1}$ millimeter. Similar features were also seen in Hole 59.2.
$\mathrm{X}$-radiographs sometimes reveal internal structures in the brown clay. Plates 2 and 3 illustrate some interesting features exhibited by these clays.

The microscopic texture shows that the brown clay is predominantly composed of minute brown granules, clay aggregates and zeolite laths. The brown granules are rich in iron (hydrousferric oxides-"limonite") and are responsible for imparting the distinctive colors to the deep sea clays. The origin of these brown granules is unknown at present, but they occur in a variety of shapes: most commonly as spherules, but also all shapes ranging from toroidal to pretzel shape. Good examples of the nature of these brown granules are seen in Plates 4 and 5, Figures 1, 2. Many of the shapes, particularly the ovals and crescents with serrated margins, the pentagons, and complex pretzel-like granules suggest an organic origin.

The sand and silt fractions in the brown clay are usually quite similar to those in the volcanic ash (see elsewhere in this chapter), mainly because most of the nonbiogenic components are of volcanic origin. The coarse fraction then mainly comprises volcanic glass, palagonite, and pumice with manganese in addition. The biogenic fraction usually comprises Radiolaria, sponge spicules and fish fragments.

Many of the clays do not reveal a fine dust-like texture, but instead they comprise an agglomeration of larger rounded clay aggregates (Plate 5, Figure 3 ). These aggregates comprise the same minute brown spherules and sometimes in addition altered glass and laths. Abundance of the latter two constituents is indicative of a volcanic origin (Plate 5, Figures 4,5).

Zeolite laths are common in many of the clays. In some cases the laths contain numerous inclusions, giving them a pale brown color; and they exhibit a parting down the center of the lath on 010 faces. Furthermore, occasional good typical cross-shaped twins confirm that these laths are the zeolite mineral phillipsite. Good examples are seen in Plate 6, Figure 5. Many smear slides contain very abundant transparent laths with refractive indices less than that of balsam. These laths, of shape and size similar to the positively identified phillipsite, are presumably of the same mineral; examples are shown in Plate 6, Figures 1-6. Plate 6, Figure 3 shows a clay containing abundant transparent laths of a much stubbier habit, but presumably also phillipsite.

\section{Mineralogical Composition}

The mineralogy of the brown clay has been studied by X-ray diffraction (Chapter 24) and smear slide examination both on ship and shore (incorporated into Part 1 of this report). In the account below, percentages of minerals given refer only to the per cent (as read from $\mathrm{X}$-ray diffraction charts) of each component within the 
crystalline material. The bulk of the material in all the brown clays is amorphous and therefore cannot be identified on the X-ray diffraction charts.

For ease of description, the sites continaing brown clay have been grouped together according to topographic provinces.

\section{Pacific Basin Floor (Sites 45 and 46)}

The two sites drilled in the Pacific Basin Floor of the Northwest Pacific, between Horizon Ridge and Shatsky Rise, provide an interesting comparison of the two main contrasting types of brown clay recovered druing Leg 6.

Oligocene brown clay from Site 45 mainly appears to be derived from a resedimented volcanic ash which has lost its coarser material (that is, $>10 \mu$ ). The clay predominantly comprises amorphous material (70 to 75 per cent), which is interpreted as being volcanic glass. The crystalline material in the clay predominantly comprises phillipsite ( 35 to 45 per cent). The phillipsite is of authigenic origin derived from the decomposition products of volcanic glass. Evidence from X-radiographs (Plate 3, Figure 1) and smear slides suggest that the phillipsite is concentrated in partially devitrified shards of volcanic material. Potassic feldspar is nearly as common as phillipsite and ranges from 20 to 40 per cent of the crystalline material. Quartz and plagioclase feldspar make up the remaining 30 per cent of crystalline material in approximately equal amounts, though either may be dominant. Occasionally, as much as 20 per cent of illite was recorded. Therefore, although clay from this site is predominantly of volcanic origin, a small eolian contribution is evident in a few places.

The Eocene to Oligocene brown clay from Site 46 is mainly of eolian origin. Like the other it contains about 70 per cent of amorphous material. Of the crystalline material, mica (40 per cent) is slightly predominant over quartz (35 per cent). Small amounts of kaolinite (12 per cent) and plagioclase ( 9 per cent) and occasionally potassic feldspar ( 2 to 4 per cent) are present. In contrast to Site 45 , the clay in Site 46 shows a marked predominance of quartz over feldspar in the ratio of about $4: 1$ (Figure 3), compared with a ratio of $1: 1$ in the clay of volcanic origin.

The heavy mineral content of the brown clays here is extremely low. Pyroxene predominates, with occasionally amphibole in addition. Limonite is common and occurs as fine silt to clay-size grains; hematite occurs rarely. Pyrite occurs as rare grains in Site 46. Radiolaria are abundant in the sand fraction from Core 1 , Hole 46.0 .

Composited 2 to 20 micron samples from the two sites show a much higher content of amorphous material in
Site 45 than in Site 46,86 per cent against 33 per cent. Phillipsite is a most important constituent of this size fraction at Site 45 making up more than half of the sample. Illite is the abundant (56 per cent) constituent of the sample from Site 46. Thus, this size fraction reemphasizes the different origin of clay from each site.

\section{Shatsky Rise (Sites 49 and 50)}

Pleistocene brown clay on the lower flanks of Shatsky Rise comprises a mixture of eolian and volcanic contributions.

In Hole 49.0 the eolian dust shows up in a predominance of quartz ( 10 to 40 per cent averaging 25 per cent) over plagioclase ( 1 to 17 per cent averaging 9 per cent). Small amounts of illite ( 15 per cent) and kaolinite (17 per cent) also occur. The volcanic contribution to the brown clay in Hole 49.0 is indicated by the occurrence of phillipsite ( 43 to 58 per cent) and montmorillonite (20 to 47 per cent). The two minerals appear to be partly antipathetic, for example, in cases where the montmorillonite content is low or even absent phillipsite occurs in abundance. The content of amorphous material from Hole 49.0 ranges from 70 to 75 per cent. The phillipsite, in particular, has a patchy vertical distribution and is best developed as sand-size twinned and zoned crystals (Plate 7, Figures 1-4) with good crystal form, in clay immediately above the unconformity (49.0-1-6, 49.1-1-2 and 3) between Pleistocene and Tithonian sediments.

In the site report for Site 49 , clay rich in montmorillonite was recognized as being of volcanic origin and described as "clay with ash" in contrast to sediment in which phillipsite was abundant which is called "zeolitic clay;" presumably disintegration of volcanic material has gone further in the latter.

In Hole 49.1 brown clay occurs in Sections 2 to 4 of Core 1 , but is interbedded with carbonates above and below. The clay is similar to that in Hole 49.0 and contains the same constituents in approximately the same proportions. However, minor variations were seen: namely the amorphous content is slightly higher, about 75 to 80 per cent, while small amounts of apatite ( 5 to 15 per cent) and potassic feldspar ( 5 per cent) occur in addition.

Amorphous material makes up 70 to 75 per cent of the clay at Site 50 . Of the remaining crystalline material, illite ( 35 to 40 per cent) is slightly predominant over quartz (30 to 40 per cent). Plagioclase makes up 15 to 20 per cent of the crystalline material. Where kaolinite is present, it makes up about 14 per cent of the clay, but when lacking, chlorite usually occurs in small amounts of about 5 per cent. Small amounts (6 per cent) of potassic feldspar also occur. Therefore, it can be seen that the material from this site is predominantly 


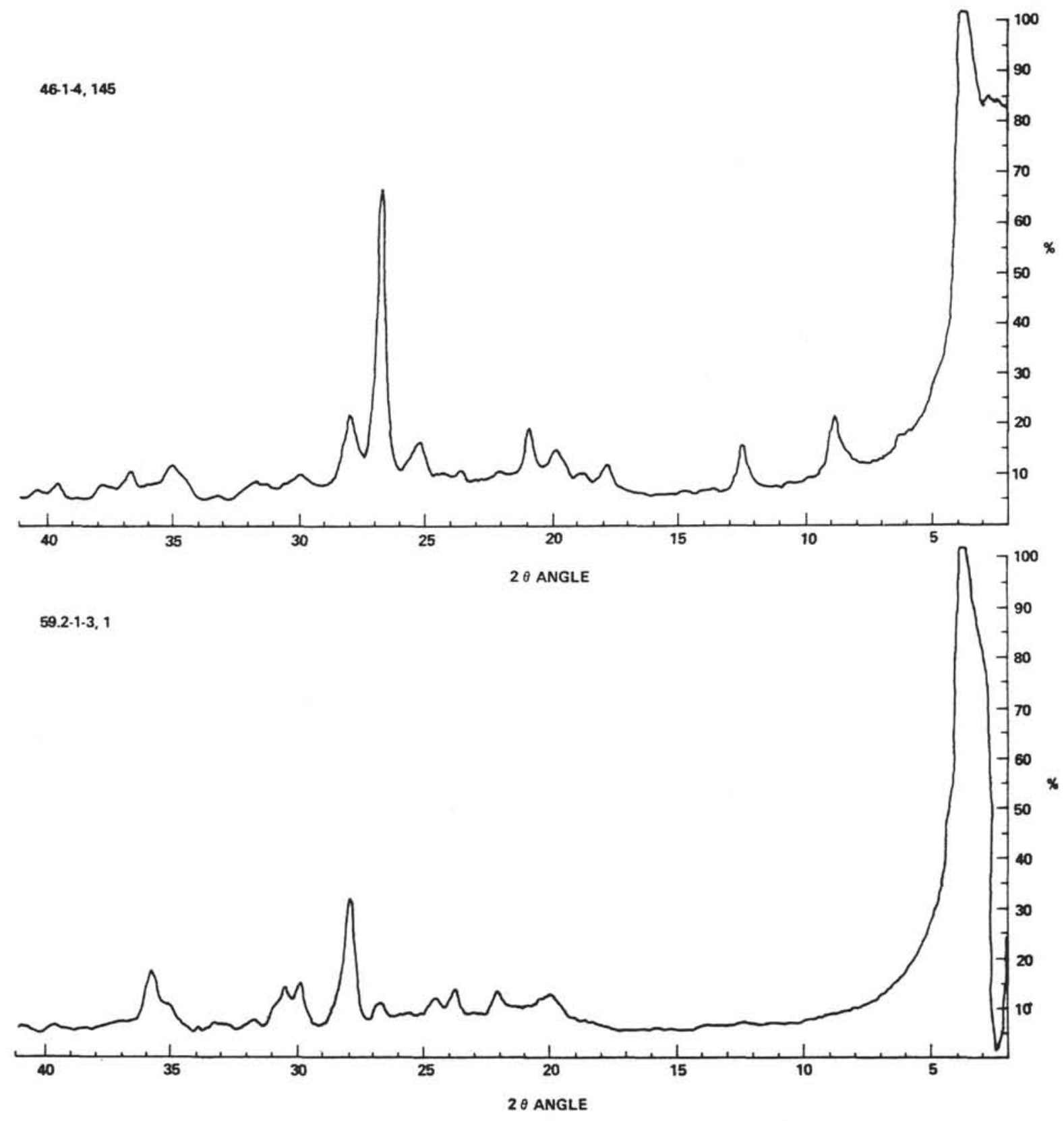

Figure 3. X-ray diffraction charts of two varieties of brown clay. 
eolian in origin, but contains a smaller volcanic contribution. The quartz to plagioclase ratio here is about 2:1. At the bottom of Hole 50.1, phillipsite becomes abundant ( 35 to 55 per cent) at the expense of the eolian constituents.

As in Site 49 phillipsite occurs as sand-size crystals in the bottom of Core 3 and in Core 4 of Hole 50.1; accurate age determinations were not possible, but this depth is believed to be close to the Pleistocene/Tithonian unconfirmity.

The high amorphous values in both Sites 49 and 50 indicate an abundance of non-crystalline material, probably volcanic glass. In smear slides abundant colorless glass and smaller quantities of brown and green glass are present. Palagonite is an abundant constituent of the sand fraction. Both sites show a decrease in the volcanic glass content with depth.

Small amounts of apatite occur in zeolitic clay in Hole 49.1, which contains a very sparse and depleted (by solution) fauna of coccoliths of Paleocene age, occurring in the lower part of Section 2, all of Section 3 , and the top part of Section 4. The remainder of this hole is in Neocomian/Tithonian calcareous sediments with no apatite.

The heavy mineral fraction mainly comprises pyroxene (monoclinic: orthorhombic 2:1), with smaller amounts of hornblende. A few grains (sand size) of pyroxene, amphibole, mica and glauconite are also present.

Nodules of manganese up to 8 centimeters in diameter are common in the top 15 meters of pelagic clay in Holes 49.1 and 50.1 (Plate 2, Figures 2, 3 and Plate 1, Figure 1, respectively). The sand fraction of the clays nearly always contains spherical manganese grains. Some of these have shapes indicating a biogenic origin, for example, faecal pellets, internal casts of foraminifera. $\mathrm{X}$-radiographs indicate that micronodules of manganese are common in many of the clays (Plates 2,3). Pebbles of white ash with a skin of manganese occur in the clay in Hole 50.1.

Opaque white fish fragments occur throughout the sediment, but are more common in the intervals immediately above and below the major unconformity on Shatsky Rise. In Core 3 of Hole 50.1 the fish fragments have an unusual bright pale green color.

Radiolaria are rare to abundant constituents of the sand fraction and in some places reworked foraminifera also occur in both sites.

In the 2 to 20 micron fraction illite is the predominant constituent of the crystalline material-it makes up about 70 per cent in Hole 49.1 and 55 per cent in
Hole 50.1. The amorphous material in both sites is between 60 and 70 per cent. Phillipsite recorded in the bulk analyses from both sites only shows up in this size fraction in Hole 49.1.

\section{Pacific Basin Floor (Sites 51 and 52)}

In Hole 51.0 the clay is predominantly of eolian origin, but there is some volcanic ash dilution. Quartz ( 30 to 40 per cent) is slightly predominant over illite ( 25 to 35 per cent) and is about four times as abundant as plagioclase (10 per cent). Small amounts of kaolinite (10 per cent) and chlorite ( 6 per cent) also occur. Occasionally, montmorillonite (up to 15 per cent) indicates that some of the clay is of volcanic origin. Phillipsite was recorded in one place.

Clay in Hole 51.1 is almost completely of eolian origin. Illite (about 35 to 40 per cent) is slightly predominant over quartz (about 35 per cent) and both are about twice as abundant as plagioclase ( 15 to 20 per cent). Chlorite is less common (usually $<10$ per cent). Potassic feldspar occurs in a few places in the late Pliocene and early Pleistocene material (23 to 32 meters), but was present in greater amounts (up to 14 per cent) in all three samples taken from 121 to 127 meters depth; the age of this deeper clay is unknown.

Phillipsite was recorded in only one place in the X-ray data, but was seen in the sand fractions from both sites and also in the smear slides as colorless laths. It shows an increase in depth in Hole 52.0, particularly from Core 5 down.

The amount of amorphous material is quite high, about 75 per cent in both sites. Smear slides show the presence of colorless volcanic glass, mainly of acid composition.

In Site 52 the clay is predominantly of eolian origin down to 20 meters depth, but contains many interbeds of clay of volcanic origin, and from 20 to 65 meters the clay is a mixture of both varieties.

Quartz and illite are the main constituents of brown clay down to a depth of about 20 meters in Hole 52.0, the latter being slightly predominant. The quartz content averages about 30 per cent (of the crystalline fraction-amorphous material here averages about 75 per cent) and illite about 34 per cent. Plagioclase is almost as abundant ( 20 to 25 per cent) while kaolinite and chlorite are minor constituents (about 8 and 3 per cent, respectively). Montmorillonite-rich layers are common in the interval 0 to 20 meters and average about 20 per cent of the clay where they occur. Potassic feldspar $(<7$ per cent) was also recorded in the 0 to 5 meter zone.

From 20 meters down quartz decreases, montmorillonite increases, illite decreases only slightly (25 to 30 
per cent), and kaolinite and chlorite are persistent as minor constituents. In addition, potassic feldspar (5 to 10 per cent) appears sporadically from 41 meters down.

Clinoptilolite $(<6$ per cent) was only recorded in the interval from 64 to 65 meters. Cristobalite makes up a high proportion ( 45 to 93 per cent) of the sediment where the chert is present, for example, in Cores 7 and 8 of Hole 52.0 .

One of the more interesting features revealed in the mineralogy of Hole 52.0 is the decrease in quartz content with depth which is recorded in Table 1. This phenomenon of decreasing quartz content with depth was also noted by Rex and Goldberg (1958). At Site 52 , brown clay layers with a considerably reduced quartz content first start appearing at a depth of 20 meters. Corresponding with this is an increase in the volcanic derived materials-mostly montmorillonite.

In addition to the usual biogenic component (that is, Radiolaria, sponge spicules, diatoms, and fish teeth and bones) the sand fraction in the brown clay in Cores 9 and 10 of Hole 52.0 contains abundant fish otoliths, the only place these were recorded in sediments from Leg 6. Rare pteropod fragments and green fish debris were seen in two different samples from Hole 52.0.

Pyroxene makes up 70 per cent of the heavy fraction and monoclinic varieties predominate over orthorhombic. In a few horizons iron ore minerals are also common.

In the 2 to 20 micron fraction illite is predominant (usually $60+$ per cent) in Site 51 and also in Site 52, but in the latter it is less common (about 40 per cent). Quartz and plagioclase are important constituents in this fraction from Site 52 each usually ranging from 20 to 30 per cent. The amorphous content is usually slightly higher in Site 52 than Site 51 in this size range.

\section{Philippine Sea (Site 53)}

A surface core ( 0 to 9 meters) was taken in brown clay at Hole 53.1, below this the sediment is volcanic ash.

The amount of amorphous material is high (about 75 per cent) and smear slides show this to be altered volcanic glass. In a few places in this site, plagioclase is quite a common component in the sand fraction, it also predominates in the bulk X-ray analysis results, ranging from 32 to 57 per cent. Illite and quartz are common averaging about 27 and 21 per cent, respectively; both are slightly more abundant in the upper layers. Chlorite ranges from 7 to 16 per cent.

In the 2 to 20 micron fraction kaolinite and montmorillonite are about as common ( 10 per cent) as quartz and illite. The remaining 60 per cent of material in this fraction is plagioclase.

\section{Caroline Ridge (Site 59)}

Brown clay from this region is interbedded with siliceous oozes, and thin ash beds, and often contains a small admixture of these sediment types.

The main brown clay sequence cored is from 52 to 61 meters and 107 to 135 meters below mud line. X-ray diffraction results show a very high amorphous scattering (usually between 80 and 90 per cent).

In Hole 59.1 (52 to 61 meters) montmorillonite and phillipsite are the most abundant constituents usually making up two-thirds of the crystalline portion of the sediment. In the sand fraction, clusters of phillipsite crystals can be seen (Chapter 22); in smear slides the phillipsite can be seen to form very abundant fine laths. Quartz and illite are present in about equal amounts (10 to 25 per cent) and decrease downwards as the amount of montmorillonite and phillipsite increase. Plagioclase and kaolinite are minor constituents.

TABLE 1

Variation in Quartz Content with Depth in Hole 52.0

\begin{tabular}{|c|c|c|c|c|}
\hline $\begin{array}{l}\text { Depth } \\
\text { (m) }\end{array}$ & Core & $\begin{array}{c}\text { Average Quartz } \\
\text { Content Per Core }\end{array}$ & $\begin{array}{c}\text { Range Quartz } \\
\text { Content Per Core }\end{array}$ & Age \\
\hline $0-9$ & 1 & 32.9 & $19.4-57.1$ ) & \multirow{3}{*}{$\begin{array}{l}\text { Middle Pleistocene- } \\
\text { Miocene }\end{array}$} \\
\hline $9-18$ & 2 & 29.3 & $21.1-33.7$ & \\
\hline $18-27$ & 3 & 24.0 & $9.0-37.9$ ) & \\
\hline $27-37$ & 4 & 21.9 & $18.4-26.7$ & $?$ \\
\hline $37-46$ & 5 & 24.3 & $20.1-32.3$ & $?$ \\
\hline $46-55$ & 6 & 17.3 & one measurement & $?$ \\
\hline $55-64$ & 7 & 19.0 & $6.8-25.3\}$ & \multirow{2}{*}{ Cretaceous } \\
\hline $64-65$ & 8 & 19.4 & $11.8-32.2\}$ & \\
\hline
\end{tabular}


This clay from 52 to 61 meters is supposedly Quaternary in age but owing to its depth has presumably slumped down the drill hole.

In Hole 59.2 (107 to 135 meters) montmorillonite and phillipsite make up 50 to 80 per cent. Clinoptilolite, plagioclase and illite are less common-about 14, 15 and 10 per cent, respectively. In Core 5 , one sample yielded 76 per cent clinoptilolite, 17 per cent quartz and 7 per cent plagioclase; this is the only place in this hole that clinoptilolite, and to a lesser extent quartz, was so abundant. The sand fraction here revealed rounded aggregates of very small radiating clusters of clinoptilolite crystals (Chapter 22). This is the singular place where this particular zeolite was found in brown clay during Leg 6 .

In the 2 to 20 micron fraction illite predominates (64 per cent) in Hole 59.1 and plagioclase in Hole 59.2. Clinoptilolite, kaolinite, rarely potassic feldspar and quartz also occur. In both holes at Site 59 the amorphous content is low ( 38 to 41 per cent).

It can be seen then that the brown clay from the Quaternary (Hole 59.1) is mainly of volcanic origin, with an eolian contribution, but in the Tertiary (Hole 59.2 ) it is almost entirely volcanic (Figure 3)-provided most of the authigenic zeolites have been derived from such material.

Optical examination of the 1.0 to 0.01 millimeter fraction showed that the plagioclase is mainly labradorite (R.I. 1.564 to 1.570 ). No quartz was seen but volcanic glass is common. Much of this glass, particularly in the sand fraction, is altered (palagonite). Brown olive glass (basic: R.I. 1.594 to 1.600 ) is predominant over green and colorless varieties.
The heavy mineral assemblage at Site 59 is very different from elsewhere. There is a sharp predominance of monoclinic pyroxene over orthorhombic pyroxene and amphibole. Also, there is a high concentration of ore minerals with epidote and garnet typical at this site.

\section{Summary}

Table 2 summarizes the ratios of the main constituents of brown clays from the Northwest Pacific. The origin of the clay is strikingly revealed by this presentation.

Holes 46 and 51.0 penetrated clay almost entirely of eolian origin.

Holes 49, 50.1, 51.1 and parts of 59.1 penetrated clay with a large eolian contribution but diluted by volcanic material.

Holes 45 , most of 52 , and 59.2 penetrated clay almost entirely of volcanic origin.

\section{Clay Mineralogy}

An X-ray analysis of the fraction $<0.001$ millimeter was made by A. Lisitzin and his co-workers (Chapter 27, Table 6). A brief summary of their results is given below.

\section{Site 45}

Brown clay from this site predominantly comprises montmorillonite ( 68 to 100 per cent) with much smaller amounts of illite and chlorite. The predominance of montmorillonite indicates the volcanic origin of most of this clay.

\section{Site 49}

Most of the brown in Hole 49.0 comprises about twothirds illite and one-third chlorite. Presumably the illite is of eolian origin. Admixtures of clay of volcanic origin

TABLE 2

Ratio of Major Crystalline Components in Brown Clays from Northwest Pacific

\begin{tabular}{lcccccc}
\hline Hole & Quartz & Plagioclase & K-Feldspar & Kaolinite & Illite & $\begin{array}{c}\text { Zeolite or } \\
\text { Montmorillonite }\end{array}$ \\
\hline 45 & 1 & 1 & 2.0 & & & 3 \\
46 & 4 & 1 & & 1.5 & 4 & \\
49 & 3 & 1 & & 1.0 & 2 & \\
50.1 & 2 & 1 & 1.0 & 2 & \\
51.0 & 4 & 1 & & 1.0 & 3 & \\
51.1 & 2 & 1 & 0.5 & & 2 & $3-5$ \\
52 & 4 & 3 & 1.0 & 1.0 & 5 & 6 \\
59.1 & 2 & 1 & & 1.0 & 2 & \\
59.2 & & 1 & & 1.0 & & \\
\hline
\end{tabular}




\section{PLATE 1}

Structures Visible in Core Sections of Brown Clay

Figures 1\&2 Hole 50.1-1-1, 41-137 cm: Pleistocene.

The interval 61 to $90 \mathrm{~cm}$ shows burrow mottles of yellowish-brown and dark yellowish-brown calcareous clay in a matrix of brown clay which contains considerably less calcareous material. From 94 to $137 \mathrm{~cm}$ these two sediment types are interbedded and do not show mottling. The interval 41 to $48 \mathrm{~cm}$ contains manganese nodules.

Figure 3 Hole 50.1-1-2, 80-148 cm: Pleistocene.

This core contains the same sediment types as in Hole 50.1-1-1, but it has been strongly deformed by drilling which has caused both mottling and flowage. Manganese nodule visible from 106 to $110 \mathrm{~cm}$.

Figure 4 Hole 51.0-1-2, 29-98 cm: Late Miocene.

"Drilling Breccia"-drilling deformation here is believed to be responsible for the formation of this breccia which comprises partially lithified fragments of zeolitic clay and diatom ooze (lighter color) in a very soft zeolitic clay matrix. 

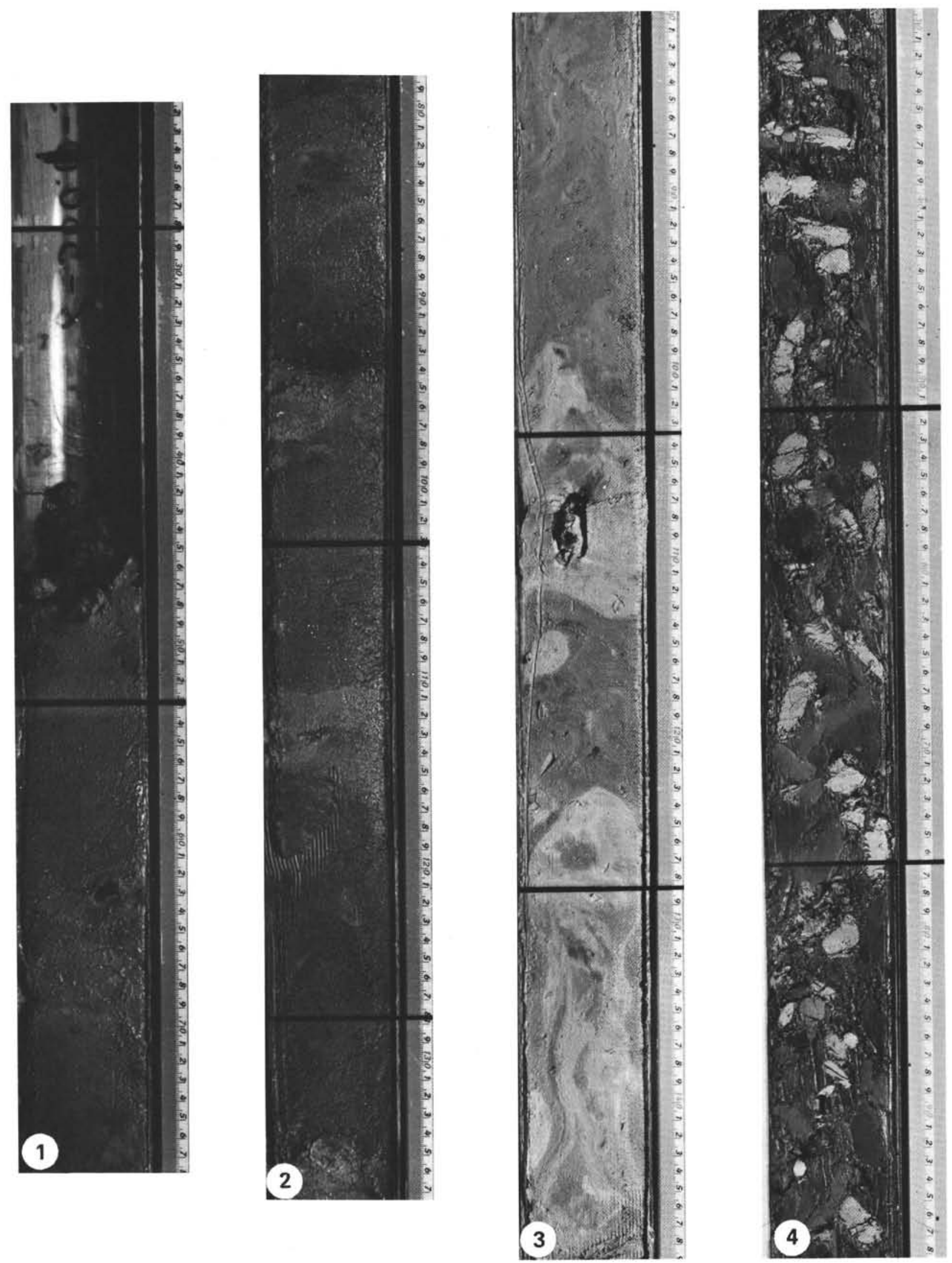


\section{PLATE 2}

X-radiographs of Structures in Brown Clay

Figure 1 Hole $46.0-1-3,90-110 \mathrm{~cm}$ : Late Eocene to Early Oligocene.

Partially lithified ash and chert (?) fragments with rare needle-shape laths (zeolite-rich ?) in clay matrix. Rounded pebble unidentified as core not split on ship.

Figure 2

Hole 49.0-1-1, 13-36 cm: Pleistocene.

Manganese nodules in zeolitic brown clay.

Figure 3 Hole 49.1-1-5, 5-32 cm: Late Jurassic or Early Cretaceous with Pleistocene admixture.

Manganese nodule in zeolitic clay in interval 5 to 15 $\mathrm{cm}$. From 15 to $32 \mathrm{~cm}$, nannoplankton chalk ooze with abundant small dark fragments (chert ground up by drilling ?) and lighter colored and larger fragments of partially lithified limestone and ash (?). 

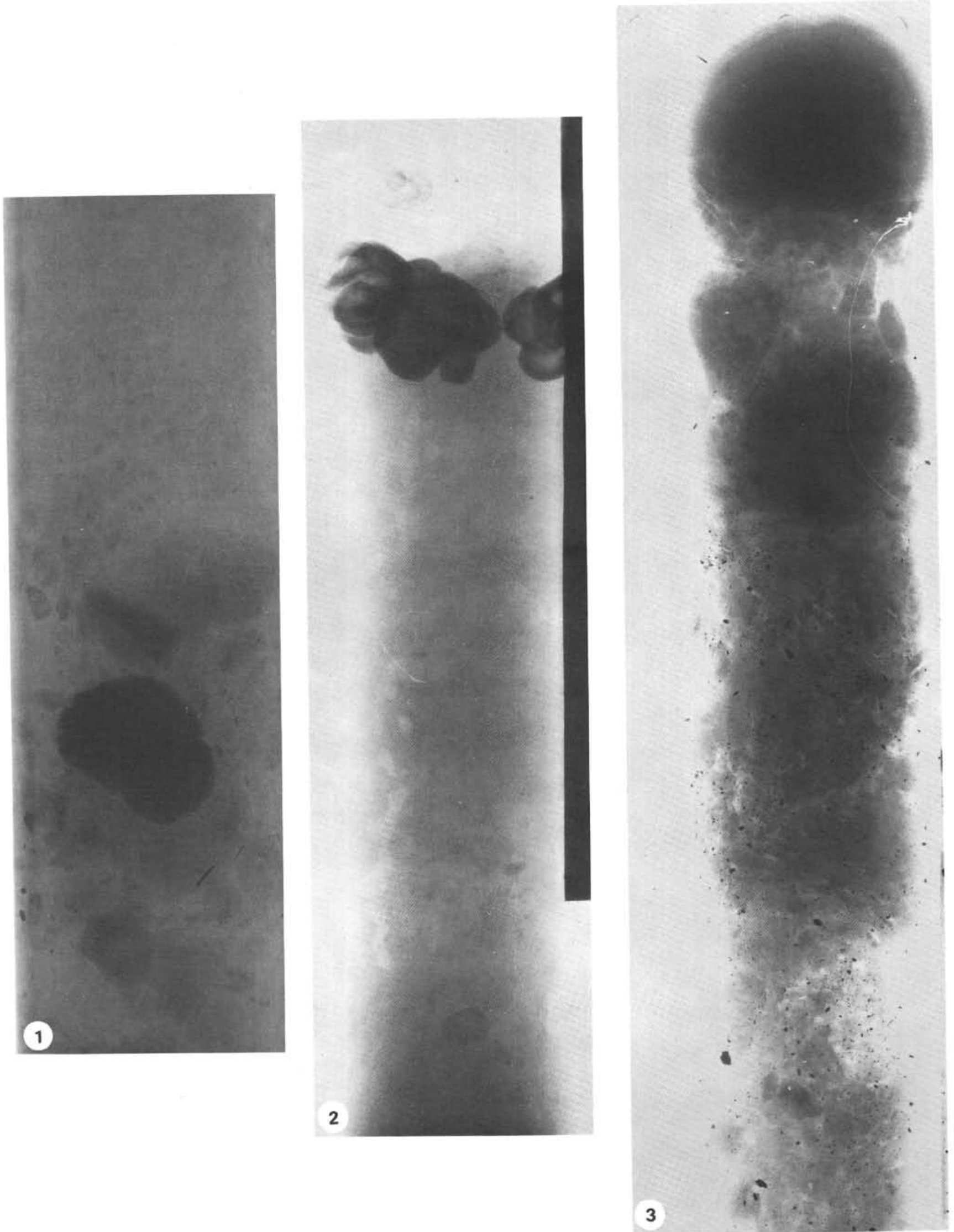


\section{PLATE 3}

X-radiographs of Structures in Brown Clay

Figure 1

Hole 45.1-1-3, 119-137 cm: Oligocene or younger (?). Zeolitic clay containing abundant needle-shape inclusions. These are rich in phillipsite and probably represent the devitrification (and conversion to zeolite) of original volcanic shards-evidence from smear slides supports this.

Figure 2 Hole 46.0-1-2, 12-29 cm: Late Eocene to Early Oligocene.

Clay containing numerous angular fragments of partially lithified ash and chert (?) with a few dark needleshape inclusions (zeolite-rich?).

Figure 3 Hole 46.0-1-3, 39-64 cm: Late Eocene to Early Oligocene.

Similar to Figure 2. 

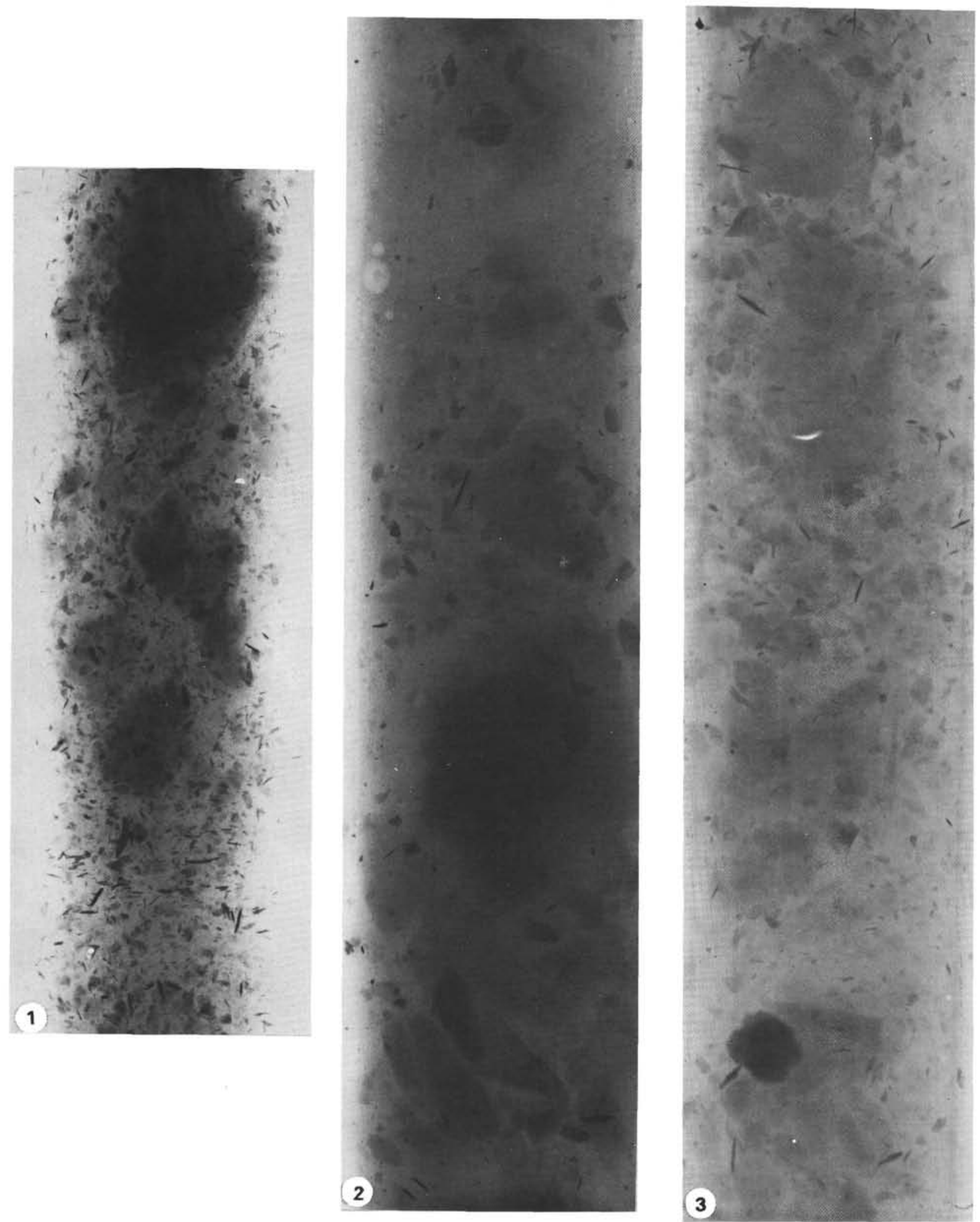


\section{PLATE 4}

Smear Slides of Iron-Oxide Granules in Brown Clay Showing Diversity of Shapes (Note, especially: ovals, ovals with serrated margins, crescents, rectangular, pentagonal and complex pretzel-like structures)

Figure 1 Hole 45.1-1-top (plain light, $X$ 170):

Oligocene or younger.

Figure 2 Hole 45.1-1-3, $140 \mathrm{~cm}$ (plain light, $X 170$ ): Oligocene or younger.

Figure 3 Hole 51.0-1-5, $137 \mathrm{~cm}$ (plain light, $X$ 170): Late Miocene.

Figure 4 Hole 46.0-1-6, $145 \mathrm{~cm}$ (plain light, $\times$ 330): Cretaceous.

Figure 5 Hole 45.1-1-top (plain light, $\times$ 330):

Oligocene or younger. 


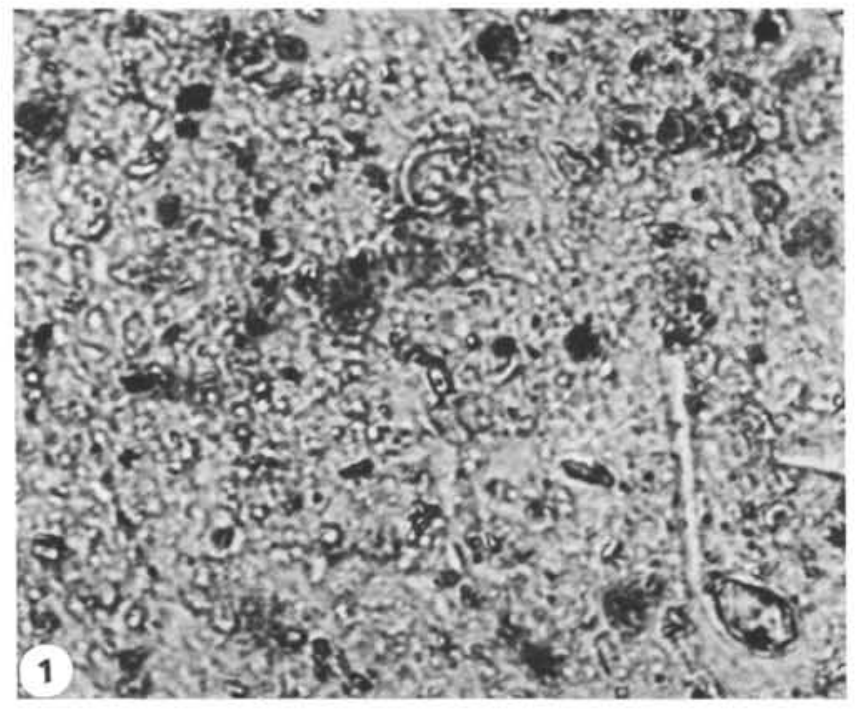

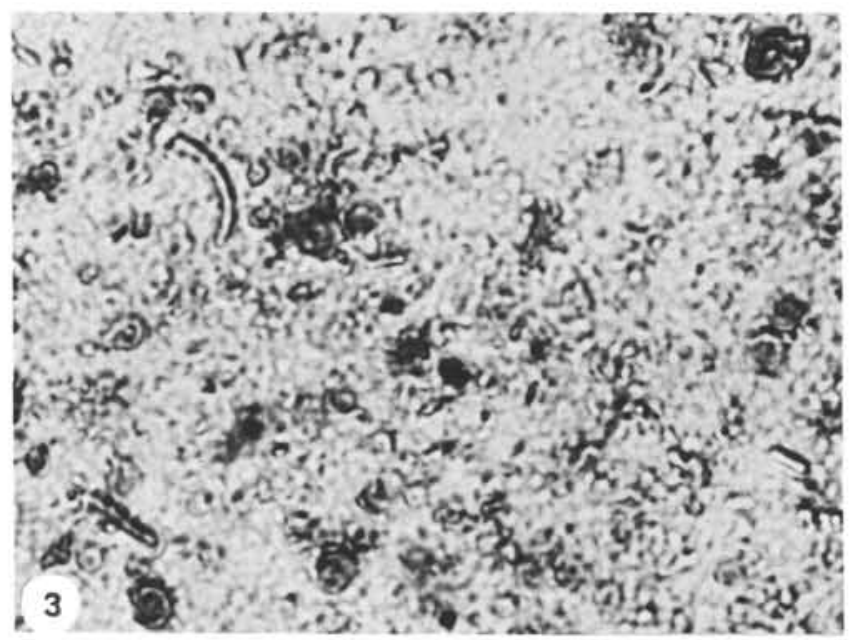

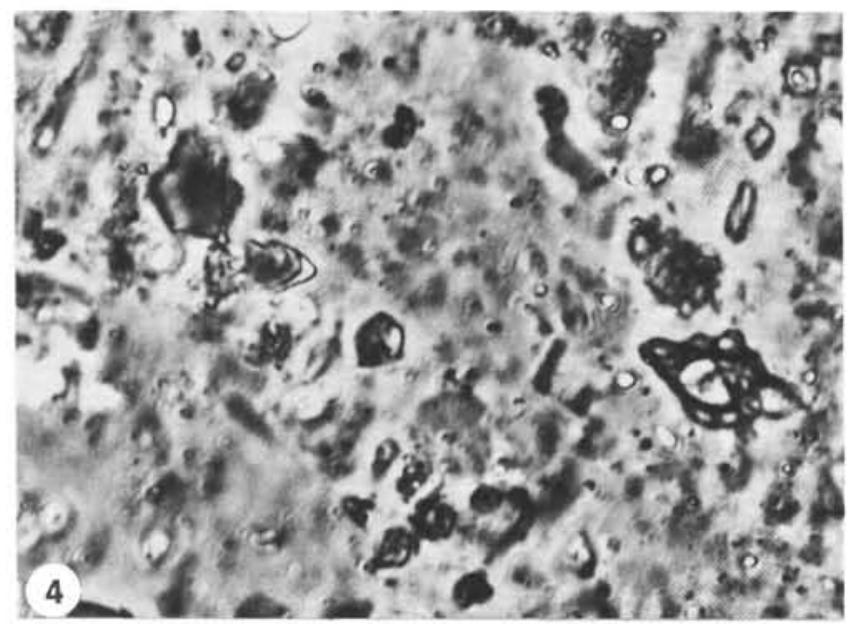

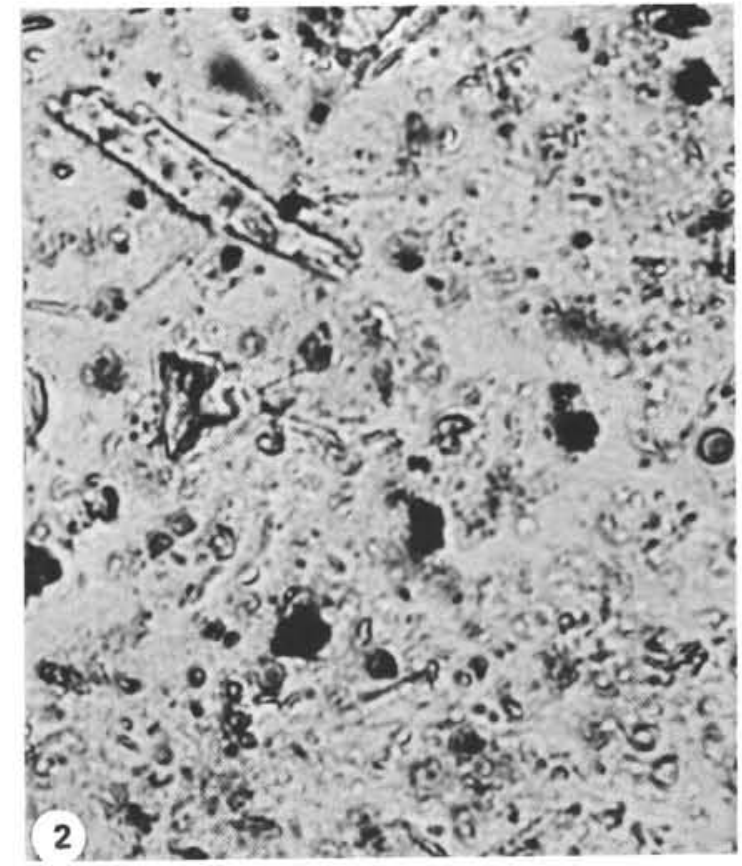


PLATE 5

Smear Slides of Brown Clay

Figure 1 Hole 51.0-1-5, $137 \mathrm{~cm}$ (plain light, $\times$ 56):

Late Miocene.

Brown clay with abundant spherical (some solid, others hollow and with or without central canal or nucleus (?) ) and some mammilary shaped iron-oxide granules.

Figure 2 Hole 49.0-1-5, $80 \mathrm{~cm}$ (plain light, $\times 56$ ):

Pleistocene,

Brown clay with abundant iron-oxide granules and a few clear zeolite laths.

Figure 3 Hole 45.1-1-3, $30 \mathrm{~cm}$ (plain light, $\times 28$ ):

Oligocene or younger.

Mainly clay aggregates comprising iron-oxide granules and zeolite laths with sparse anhedral feldspar grains.

Figure 4

Hole 50.1-2-2, $80 \mathrm{~cm}$ (plain light, $X 28$ ):

Pleistocene.

Clay comprising clay aggregates, iron-oxide granules, glass shards, feldspar, Radiolaria, sponge spicule and diatom fragments.

Figure 5 Hole 50.1-1-4 (plain light, $\times 28$ ):

Pleistocene.

Clay similar to Figure 4. 

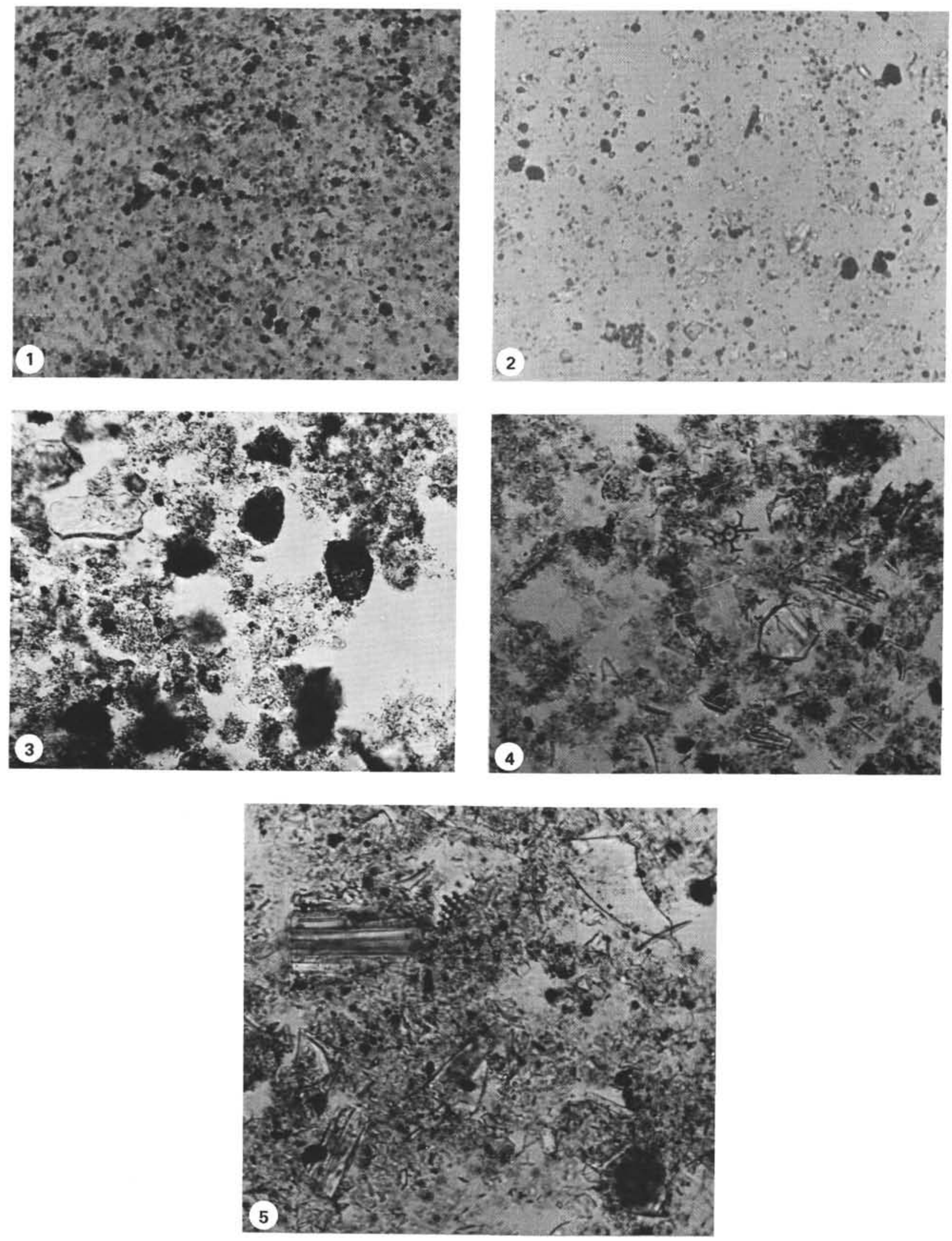


\section{PLATE 6}

Smear Slides of Zeolitic Brown Clay

Figure 1

Hole 45.1-1-3, $140 \mathrm{~cm}$ (plain light, $\times 56$ ):

Oligocene or younger.

Zeolitic clay with abundant phillipsite laths. Less common iron-oxide granules and anhedral feldspar grains.

Figure 2 Hole 51.0-1-2, $72 \mathrm{~cm}$ (plain light, $\times$ 56):

Late Miocene.

Zeolitic clay with iron-oxide granules, phillipsite laths and rare glass shards.

Figure 3 Hole 46.0-1-3, $150 \mathrm{~cm}$ (plain light, $\times$ 80):

Late Eocene to Early Oligocene.

Zeolitic clay. Note shorter stubby phillipsite laths, minute iron-oxide granules and one glass shard.

Figure 4 Hole 59.2-5-1, $140 \mathrm{~cm}$ (plain light, $X 56$ ):

Upper Eocene to Lower Oligocene.

Zeolitic clay. Phillipsite laths here are extremely numerous and particularly thin. Iron-oxide granules are common.

Figure $5 \quad$ Hole $49.1-1-3,109 \mathrm{~cm}$ (plain light, $\times 28$ ):

Late Jurassic or Early Cretaceous mixed with Pleistocene.

Zeolitic clay. Note phillipsite twins and laths, clay aggregates, minute iron-oxide granules, and rarely anhedral amphibole grains. 

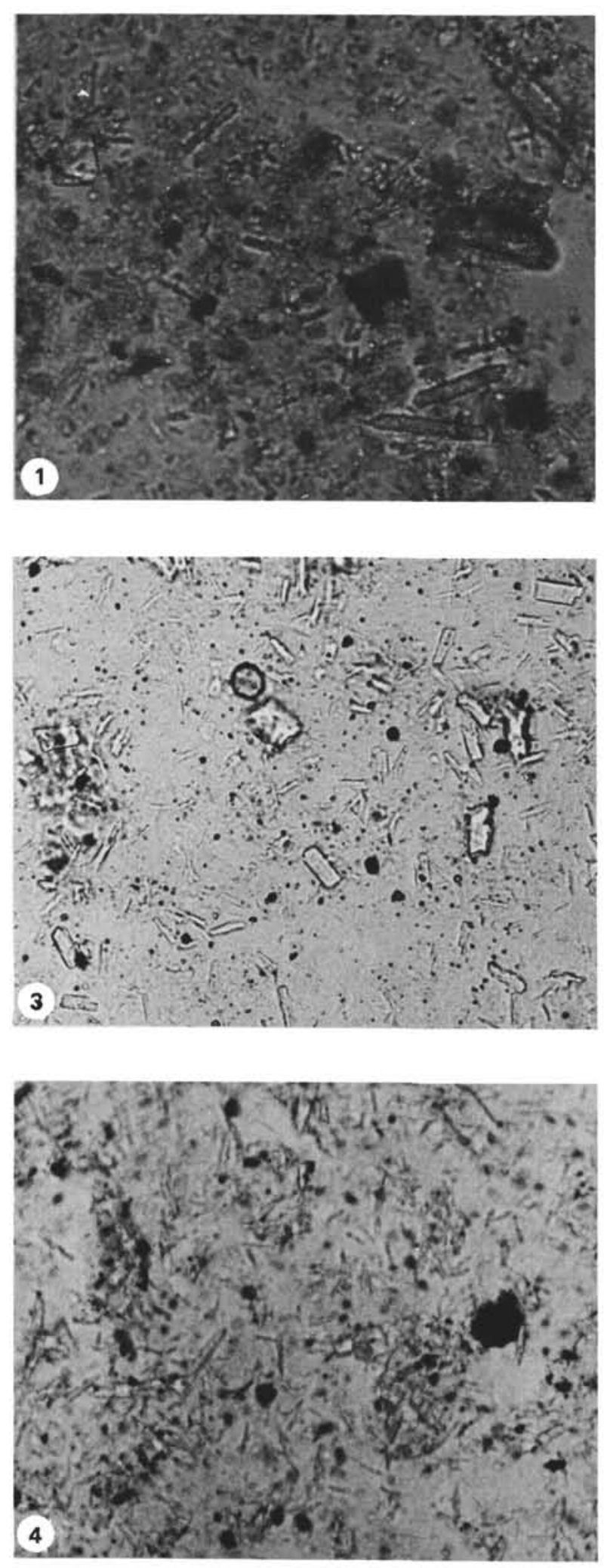
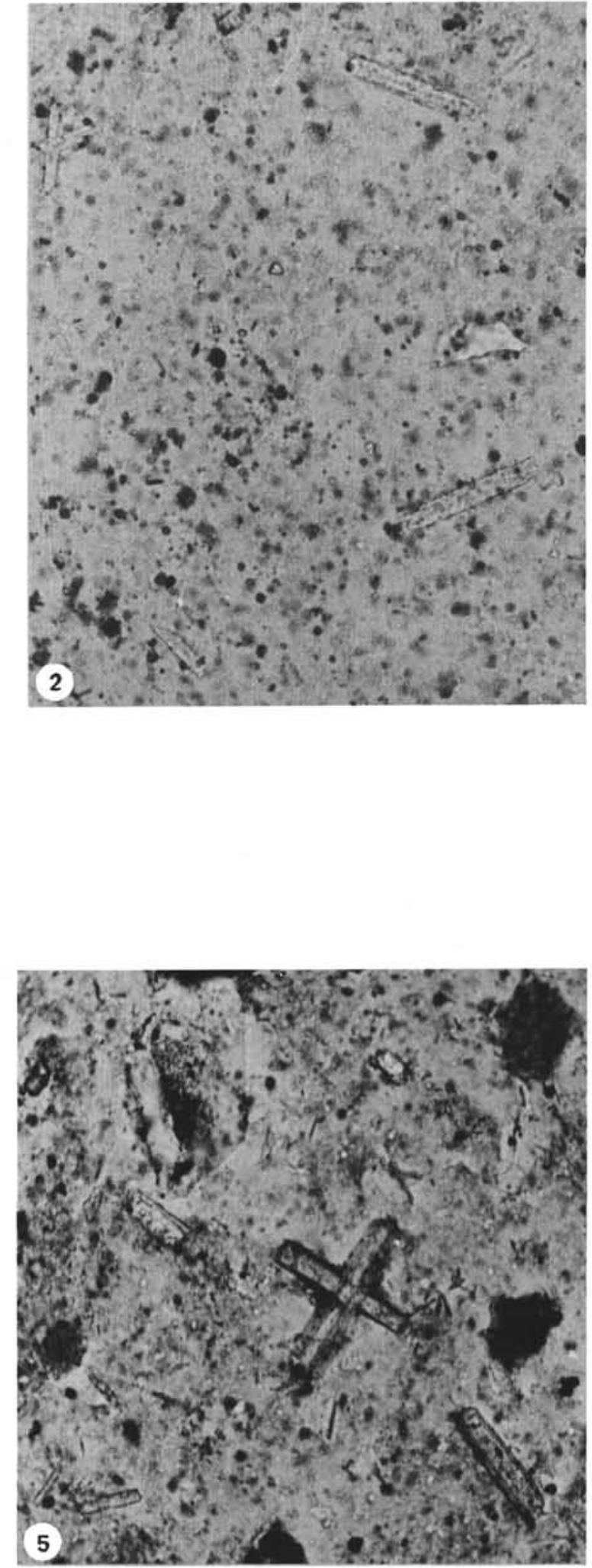


\section{PLATE 7}

Photographs of Phillipsite Crystals

Figures 1 to 3 microphotograph of sand fraction-Figure 4 electroscan of sand fraction.

Figure 1 Hole 49.1-1-2, $119 \mathrm{~cm}$ (plain light, $X$ 56):

Close to Upper Jurassic/Pleistocene unconformity on Shatsky Rise. Note zoning in crystal.

Figure 2 Hole 49.1-1-2, $119 \mathrm{~cm}$ (plain light, $\times 17$ ):

Note single, twinned, and clusters of phillipsite crystals.

Figure 3

Hole 49.1-1-2, $119 \mathrm{~cm}$ (plain light, $\times 56$ ):

Twinned phillipsite crystal-note parting down center of 010 faces.

Figure 4

Hole 49.1-1-2, $119 \mathrm{~cm}$ (electroscan, $X 100)$ :

Phillipsite crystals abundant with few feldspar grains and fish teeth. 

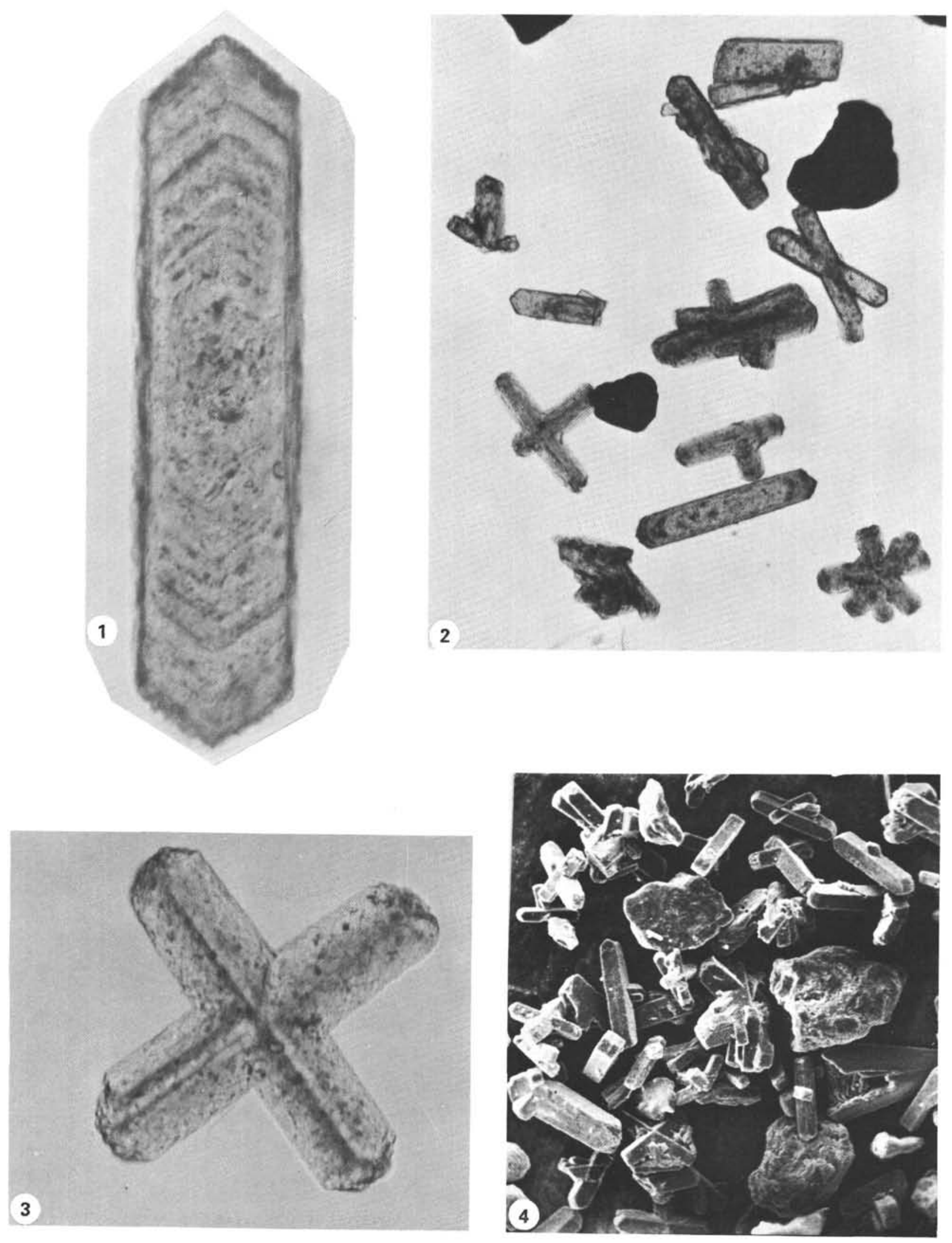


\section{PLATE 8}

X-ray Radiographs

Figure 1 Hole 47.0-1-5, 75.5-106 cm: Pleistocene.

Nannoplankton chalk ooze with pyritized burrows.

Figure 2 Hole 47.1-1-1, 2.5-32.5 cm: Paleocene.

Highly disturbed nannoplankton chalk ooze with rounded lumps of more cohesive sediment in soupy "matrix."

Figure 3 Hole 47.2-2-3, 80-98.5 cm: Pleistocene.

Layered nannoplankton chalk ooze deformed during coring. Dark fragments are angular pieces of pumice and volcanic glass. 

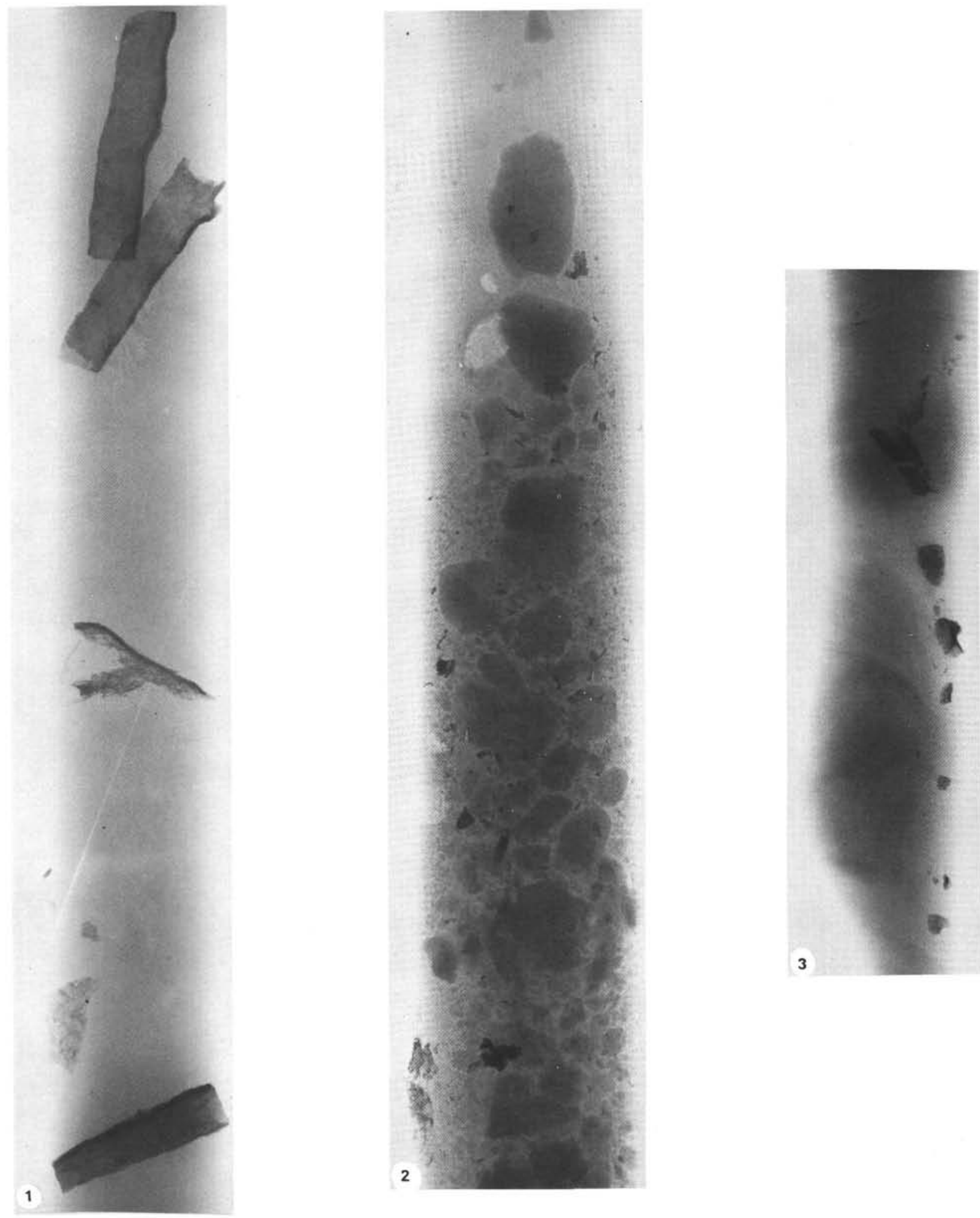


\section{PLATE 9}

X-ray Radiographs

Figure 1

Figure 2

Figure 3
Hole 47.2-13-5, 10.5-35.5 cm:

Upper Cretaceous (Maestrichtian).

Nannoplankton chalk ooze; this particular section was not split open, but dark fragments visible are probably pieces of chert and pelecypod shells broken apart during coring.

Hole 48.2-2-1, 8.0-33.5 cm: Upper Cretaceous (Maestrichtian).

Nannoplankton chalk ooze containing fragments of pelecypod shells and possibly chert.

Hole 48.2-2-5, 80.5-108 cm:

Upper Cretaceous (Maestrichtian).

Nannoplankton chalk ooze containing large pelecypod (Inoceramus?) shell fragments. 

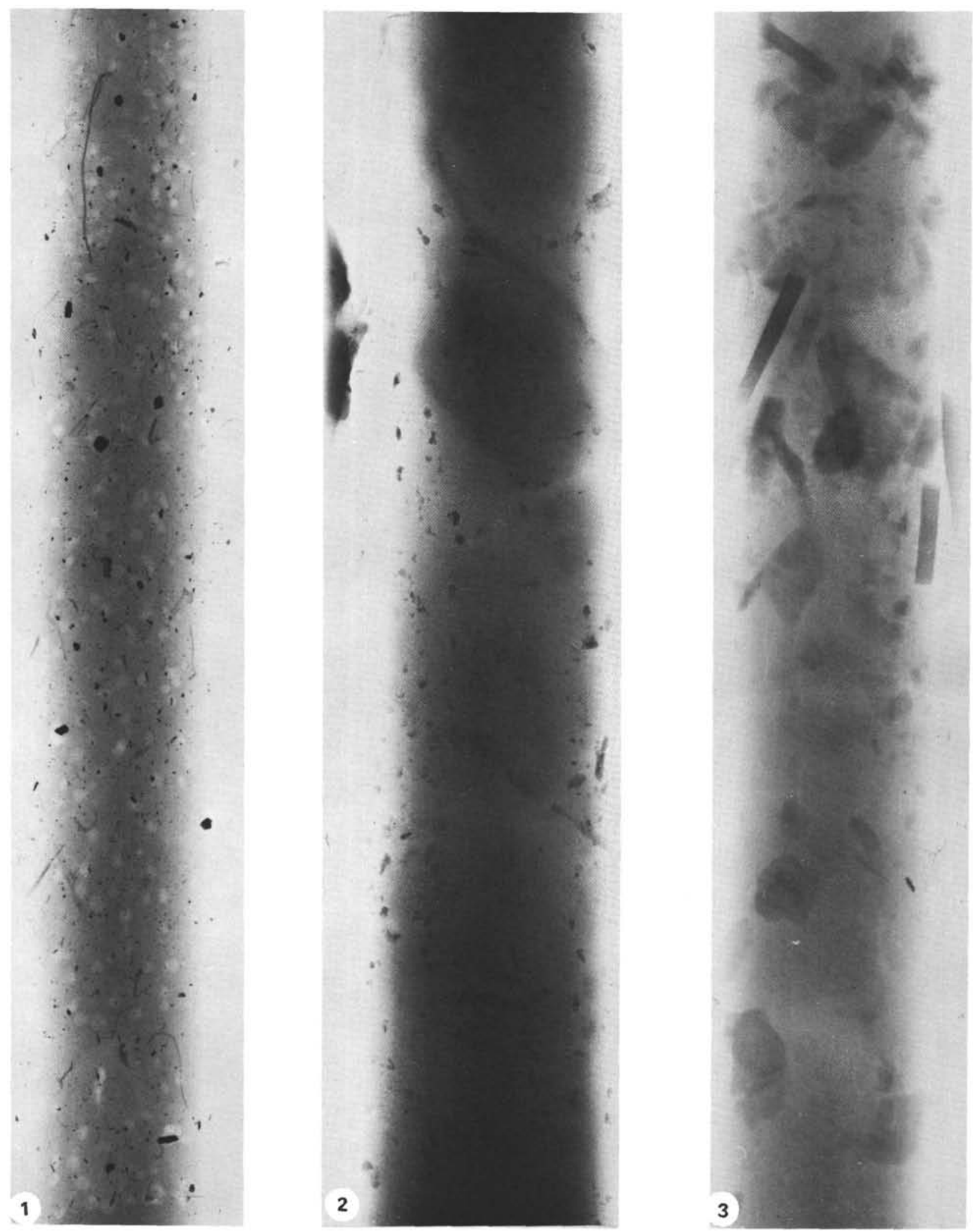
PLATE 10

X-ray Radiographs

Figure 1

Hole 49.1-1-4, 39.5-74.5 cm:

Upper Jurassic (Tithonian).

Upper part is brown zeolitic clay with small pebbles of soft white volcanic ash and hard brown chert. Lower one third is highly mottled mixture of nannoplankton chalk ooze and dark brown zeolitic clay.

Figure 2 Hole 49.1-1-4, 76-112 cm:

Jurassic Upper (Tithonian).

Upper part is highly mottled mixture of white nannoplankton chalk ooze and dark brown zeolitic clay. Lower one third is white nannoplankton chalk ooze.

Figure 3 Hole 50.0-2-1, 48.5-73.5 cm:

Upper Jurassic.

Highly disturbed nannoplankton chalk ooze containing angular to subrounded fragments of chert (?), probably broken apart during coring. 

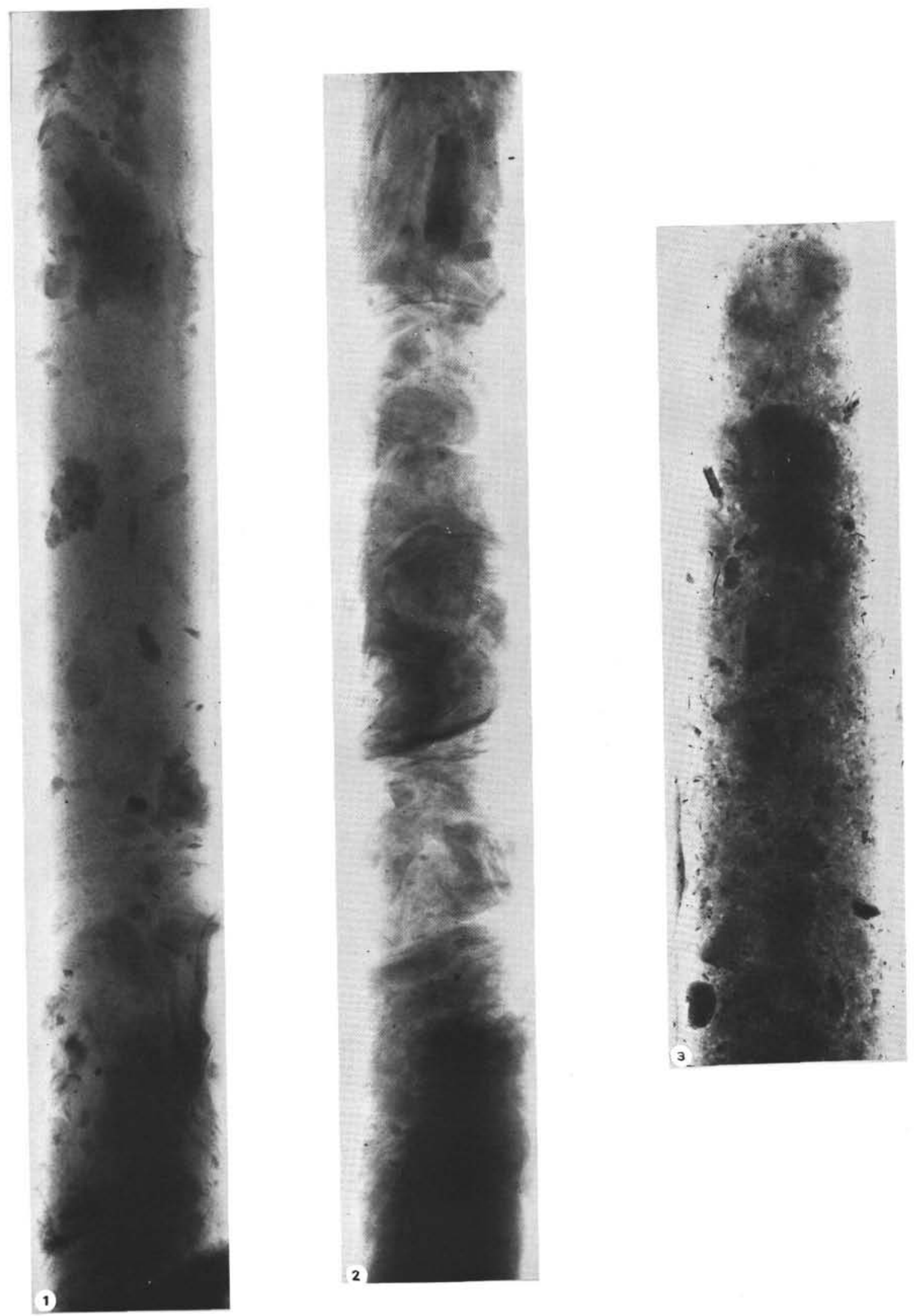
are shown in the presence of montmorillonite (for example, 49.0-1-5, $70 \mathrm{~cm}$ ). In Hole 49.1 both illite and montmorillonite predominate in different parts of the hole. Chlorite is usually present in smaller amounts (10 to 20 per cent).

\section{Site 50}

Illite usually makes up over half of the clay fraction with montmorillonite and/or chlorite making up the remainder. The eolian contribution to the brown clay then is greater than the volcanic in this site.

\section{Site 51}

The only sample from this site predominantly comprises montmorillonite, the remaining half of the clay being made up of illite and a smaller amount of chlorite.

\section{Site 52}

In this site much of the clay is of volcanic origin and is also interbedded with volcanic ash. Montmorillonite is, therefore, dominant, often to the exclusion of other clay minerals. The eolian contribution to the brown clay is apparent in some samples where illite ranges from 27 to 40 per cent. Chlorite is a minor constituent ranging from 9 to 12 per cent.

\section{Minor constituents}

Among the minor constituents the only mineral which shows any sort of consistent pattern of occurrence in the brown clays is palygorskite. This mineral is commonly present, except where montmorillonite becomes dominant (for example, Site 52).

\section{Chemical Composition}

Complete tables of analyses results on many hundred samples of Leg 6 samples are given in Chapter 27. The analyses were made by Dr. A. Lisitzin and co-workers at the Academy of Sciences, U.S.S.R., whose intensive efforts are gratefully acknowledged here.

A brief survey of the results was made by this author and some general observations, plus in a few cases some important features of the chemical composition of the brown clay are pointed out here.

\section{Manganese, Titanium and Trace Elements}

Core averages of analyses of manganese, titanium and trace elements are given in Table 3 and a bar graph in Figure 4.

TABLE 3

Hole Averages of Manganese, Titanium and Trace Elements in Brown Clay in Northwest Pacific (Reported as Parts per Million)

\begin{tabular}{|c|c|c|c|c|c|c|c|c|c|c|}
\hline Site & $\mathrm{Mn}$ & $\mathrm{Ti}$ & $\mathrm{Cr}$ & V & $\mathrm{Ni}$ & Co & $\mathrm{Zr}_{\mathrm{r}}$ & $\mathrm{Cu}$ & $\mathrm{Pb}$ & $\mathrm{Mc}$ \\
\hline 45 & 5027 & 11955 & 273 & 186 & 378 & 104 & 208 & 171 & 8 & 31 \\
\hline 46 & 6340 & 2942 & 41 & 84 & 148 & 55 & 158 & 210 & 37 & 26 \\
\hline 49 & 8250 & 2746 & 49 & 81 & 176 & 78 & 124 & 23 & 52 & 13 \\
\hline $50^{\mathrm{a}}$ & 6091 & 3616 & 51 & 97 & 212 & 53 & 147 & 330 & 55 & 16 \\
\hline 51 & 11245 & 3556 & 45 & 108 & 222 & 130 & 168 & 471 & 74 & 27 \\
\hline 52 & 6200 & 3369 & 45 & 104 & 139 & 55 & 163 & 358 & 39 & 14 \\
\hline $53^{\mathrm{b}}$ & 9333 & 4266 & 32 & 150 & 82 & 44 & 85 & 563 & 49 & 14 \\
\hline $59^{\mathrm{c}}$ & 6575 & 6993 & 85 & 114 & 215 & 55 & 137 & 242 & 31 & 10 \\
\hline \multicolumn{11}{|c|}{ Sediment Averages } \\
\hline Argillaceous $^{\mathrm{d}}$ & - & - & 55 & 390 & 300 & 100 & 126 & 400 & 175 & 17 \\
\hline $\begin{array}{l}\text { Pacific } \\
\text { Pelagic }^{\mathrm{e}}\end{array}$ & - & - & 93 & 450 & 320 & 160 & 180 & 740 & 150 & 45 \\
\hline
\end{tabular}

\footnotetext{
${ }^{\mathrm{a}}$ Site 50 data from Hole 50.1, Core 2, only.

$\mathrm{b}_{\text {Site }} 53$ data from Hole 53.1, Core 1, only.

c Site 59 data from Hole 59.1, Core 3 and Hole 59.2, Cores 3-6 only.

dWakeel and Riley (1961).

${ }^{\mathrm{e}}$ Goldberg and Arrhenius (1958).
} 

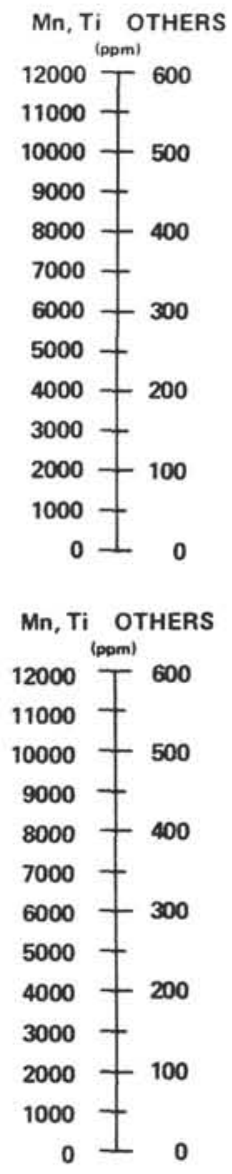

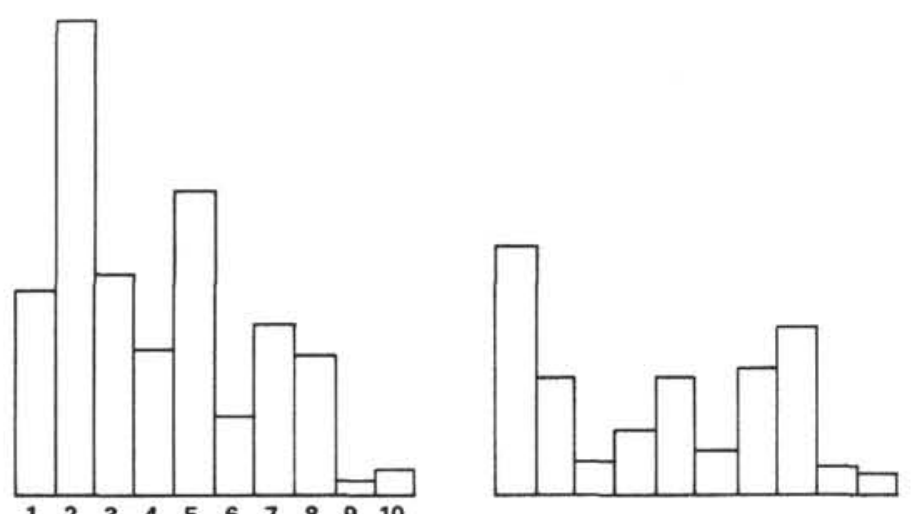

$\begin{array}{cccccccccc}1 & 2 & 3 & 4 & 5 & 6 & 7 & 8 & 9 & 10 \\ M n & \mathrm{Ti} & \mathrm{Cr} & \mathrm{V} & \mathrm{Ni} & \mathrm{Co} & \mathrm{Zn} & \mathrm{Cu} & \mathrm{Pb} & \mathrm{Mo}\end{array}$ SITE 45

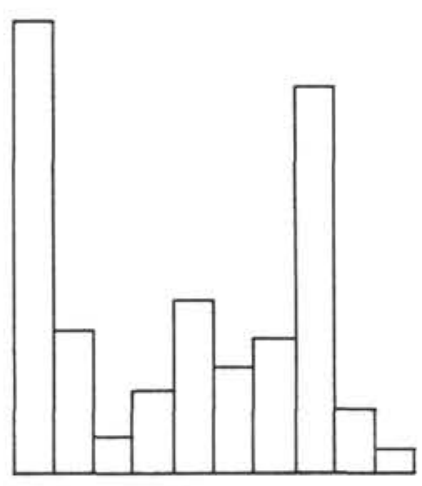

SITE 51
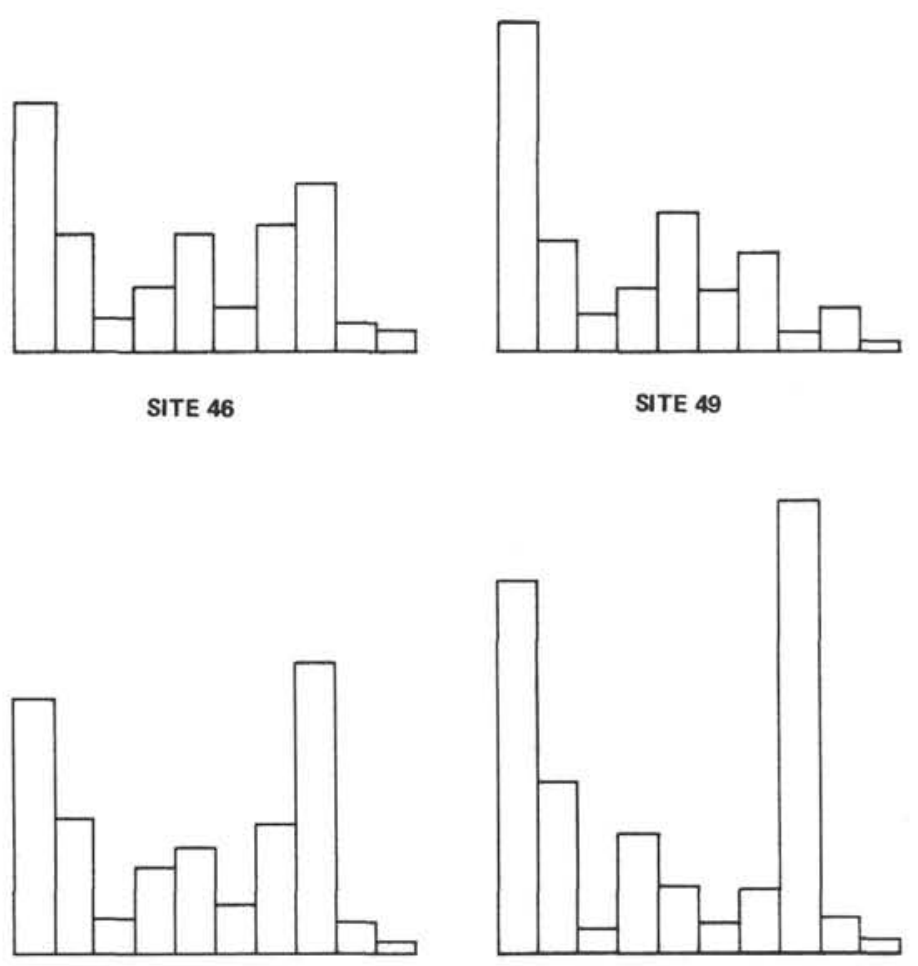

SITE 52
SITE 49

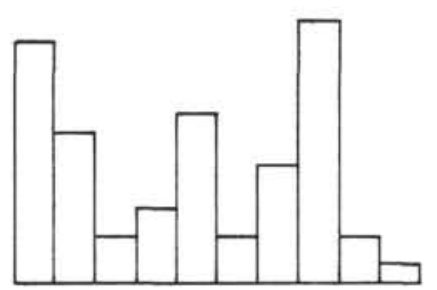

SITE 50

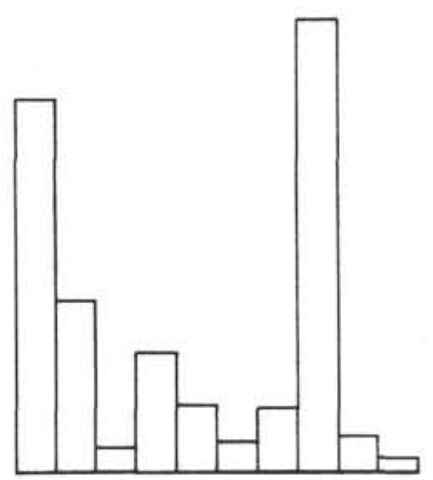

SITE 53

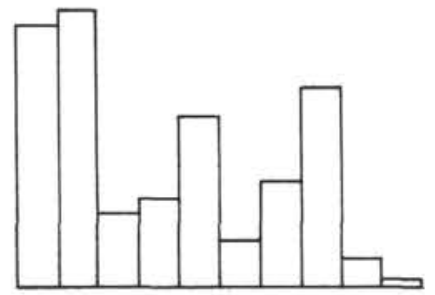

SITE 59

ま

Figure 4. Bar graph of manganese, titanium and trace elements in brown clay. 
The manganese content is usually about $6000 \mathrm{ppm}$, but Site 51 shows a much greater concentration up to $23,000 \mathrm{ppm}$ with an average of $11,000 \mathrm{ppm}$.

The nickel content usually varies from about 140 to $220 \mathrm{ppm}$, but in Site 45 there is a marked concentration-up to $600 \mathrm{ppm}$ with an average for the hole of $380 \mathrm{ppm}$.

Revelle et al. (1955) pointed out a marked covariance of manganese and nickel over a wide range of manganese concentration. Figure 5 shows the Leg 6 samples plotted for these two minerals. It can be seen that despite the wide variations there is a general covariance: the greater the manganese content, the higher the nickel, also. An attempt to draw curves to fit the point values was made, but the only reasonable correlation was for Site 51. The same authors also noted that older clays tend to contain less nickel with the same manganese content. The Leg 6 results do not help in evaluating this observation. The only site which continuously cored brown clay for any depth was Site 52, and here both the nickel and manganese contents show a marked increase with depth, though from Core 6 down, the $\mathrm{Mn}: \mathrm{Ni}$ ratio is usually halved (Table 4). The range of nickel and manganese values show a wide scatter and accurate age dating of these brown clays in Site 52 is not possible.

The trace element analysis of clay from Site 45 reveals that this material is considerably richer in titanium, chromium, vanadium, nickel, cobalt and zirconium (Figure 4). This is thought to be related to the origin of the brown clay. The chemical evidence supports that of the mineralogy (smear slide and X-ray data) which revealed this clay to be predominantly derived from the breakdown of volcanic constituents on the sea floor. Goldberg and Arrhenius (1958) noted that an excess of

TABLE 4

Core Averages for Manganese and Nickel in Hole 52

\begin{tabular}{cccc}
\hline Core & Mn & Ni & Mn:Ni \\
\hline 1 & 4331 & 79 & 59 \\
2 & 4685 & 74 & 63 \\
3 & 4025 & 64 & 62 \\
4 & 3086 & 53 & 58 \\
5 & 6714 & 94 & 71 \\
6 & 7700 & 210 & 36 \\
7 & 3300 & 171 & 19 \\
8 & 9990 & 307 & 32 \\
9 & 9800 & 150 & 65 \\
10 & 18000 & 480 & 37 \\
\hline
\end{tabular}

chromium (7100 ppm) was indicative of a basaltic source. In Site 45 the chromium values were more than double this amount and 5 to 6 times higher than in clay of terrestrial (eolian in this part of the Pacific) origin. It is interesting to note that volcanic ash (Sites $53,54,60$ ) from the Mariana area has a low content of chromium-10 to $30 \mathrm{ppm}-$ and this is because the source volacnoes are of intermediate to acid composition. The high titanium content also indicates a basaltic source for the clay at Site 45.

The titanium and chromium contents in clay from Site 59 are about double those in Sites 46, 49, 50, 51 and 52 and probably reflect a basaltic component although they are still much lower than in Site 45. It was noted earlier that the plagioclase in Site 59 was mainly labradorite.

The copper content in clays from Leg 6 is usually 200 to $300 \mathrm{ppm}$, but Sites 51 and to a lesser extent Site 52 show a relative increase in this mineral. Compared with average values for the Pacific given in Table 3, it would appear that Sites 51 and 52 are the more typical and the other sites drilled showed a relative paucity of these minerals. Site 49 shows a much lower content of copper than usual.

According to Revelle et al. (1955) pelagic clays contain varying amounts of biogenous copper, in addition to the hydrogenous copper carried by manganese oxides. Biogenous copper, probably associated with soft parts or end products of metabolism may accumulate at rate generally proportional to rate of deposition of calcareous shells.

This discussion is concerned here with deep-sea brown clays from which most calcareous material has been dissolved. Compared with carbonates recovered on Leg 6 (Chapter 27, Table 10) these clays show a much greater concentration of copper as one would expect.

Lead shows an apparent depletion in Site 45 (average $8 \mathrm{ppm}$ ) and elsewhere ranges from 29 to $74 \mathrm{ppm}$, which is much lower than the average values reported by other workers (Table 3). Molybdenum ranges from 9 to $31 \mathrm{ppm}$ in brown clay.

\section{Alkaline Elements}

Sodium and potassium show a fairly uniform range of values in the brown clay. Core averages ranged from about 1.00 to 1.50 per cent for sodium and 0.70 to 1.20 for potassium. Site 59 was the only one to show slightly higher values of sodium-1.75 per cent.

In Sites 46, 49, 50, 52 and 59, lithium and rubidium occur in trace amounts- -0.004 to 0.005 and 0.010 to 0.015 , respectively. However, in Sites 45 and 51 they show a remarkable increase in concentration. Lithium 


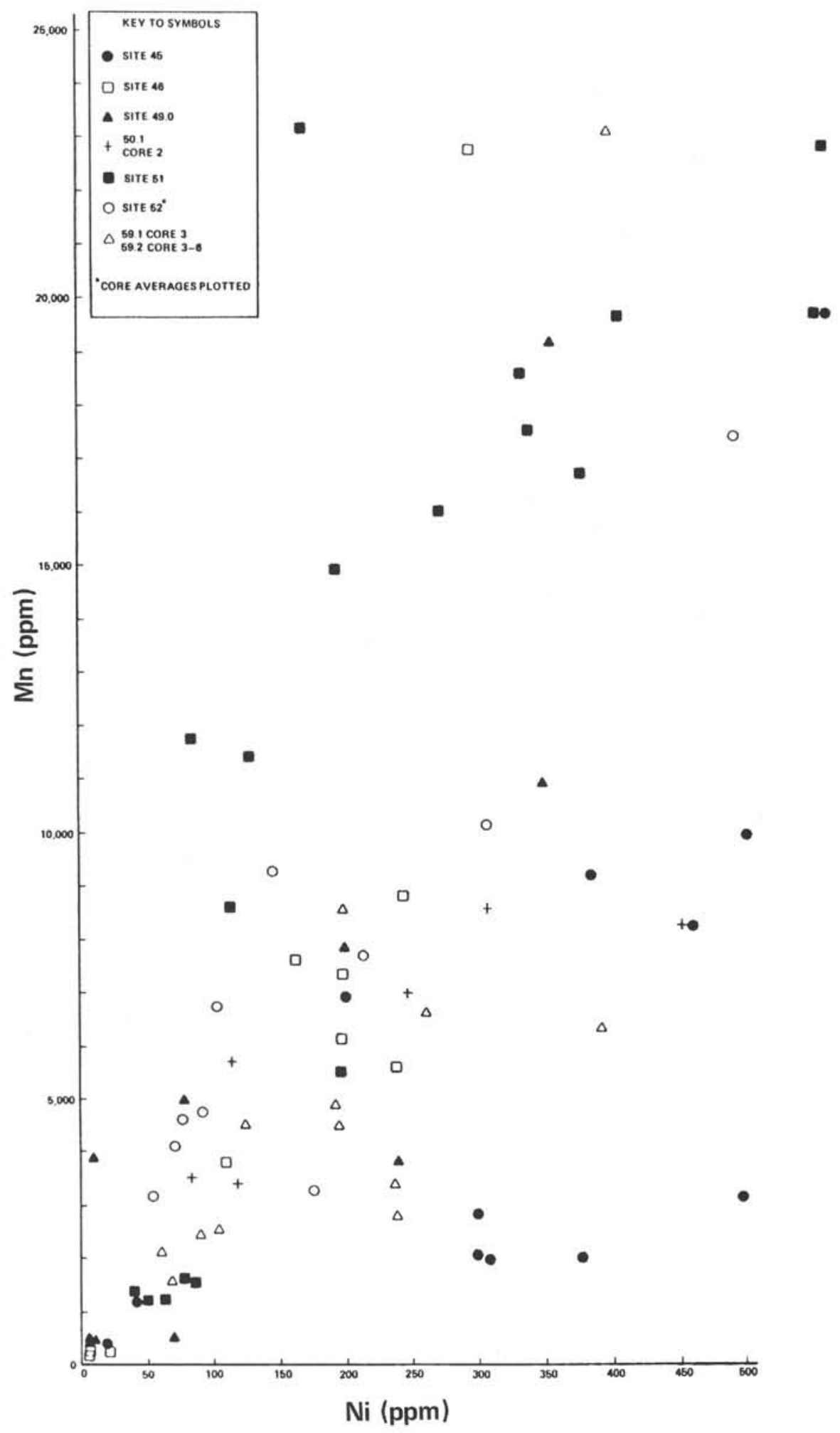

Figure 5. Plots of manganese against nickel in brown clay. 
averaged 0.377 in Site 45 and 0.5100 in Site 51 and rubidium averaged 0.473 and 1.221 , respectively. The reason for this relative enrichment in these two sites is not understood.

Cesium core averages ranged from 0.005 to 0.0010 , but clay from Site 49 had much higher concentrations0.0187 .

\section{Iron, Manganese and Titanium Oxides}

Plots of total iron (as $\mathrm{Fe}_{2} \mathrm{O}_{3}$ ) against manganese oxide $(\mathrm{MnO})$ are shown in Figure 6. In most holes the manganese oxide content is constant (at around 0.2 per cent) over a wide range of total iron values ( 2 to 8 per cent). Higher values of iron $\left(\mathrm{Fe}_{2} \mathrm{O}_{3}\right)$ were recorded from Holes 45.1 and 59.2 where the clay is mainly of volcanic origin.

Plots of $\mathrm{Fe}_{2} \mathrm{O}_{3}$ (total iron) against titanium oxide $\left(\mathrm{TiO}_{2}\right)$ show a marked linear relationship (Figure 7). This has been previously observed by other workers (Wakeel and Riley, 1961; and Revelle et al., 1955) in deep sea clays regardless of the origin of the clay.

\section{Silica and Alumina}

Plots of silica $\left(\mathrm{SiO}_{2}\right)$ against alumina $\left(\mathrm{Al}_{2} \mathrm{O}_{3}\right)$ for each site in which brown clay was recovered are given in Figure 8. If a brown clay is of terrestrial origin, the plots should fall along a straight line in contrast to a clay of volcanic origin where the plots would not show such a linear relationship but a greater scatter.

Unfortunately, there are not sufficient plots for some of the Leg 6 sites (46 and 53) to enable any conclusions to be made. However, some do clearly demonstrate the type of clay present. A look at Figure 8 shows that the plots for Sites 52 and 59 and possibly also 45 show a nonlinear scatter and those for Sites 49, 50 and 51 do have a linear trend.

\section{CARBONATE SEDIMENTS}

$$
\text { (R. E. G.) }
$$

The carbonate sediments recovered during Leg 6 are of two main types: (1) chalk and marl oozes, usually with abundant nannoplankton and occasionally with abundant foraminifera, and (2) carbonate silts, sands and gravels.

\section{Chalk and Marl Oozes}

These deposits, volumetrically the most abundant type of sediment encountered on Leg 6, generally have 50 to 90 per cent calcareous nannofossils along with variable amounts of planktonic foraminifera, siliceous microfossils, volcanic glass shards, clay minerals and other minor impurities. Ages of chalk oozes encountered vary from Pleistocene (Holes 47.0, 47.2, 55.0 and 58.1) to
Late Jurassic (Holes 49.1 and 50.0). Calcareous pelagic oozes of this type were the dominant type of sediment encountered on rises and ridges (Horizon Ridge, Shatsky Rise, Caroline Ridge), and were either subordinant or absent in the sections cored in other areas. Thick sequences of these oozes were cored continuously at Sites 47 and 55, and intermittent coring suggests similar thick sections are also present at Sites 44, 48, 56 and possibly 57.

Estimated mean sedimentation rates for oozes of this type show considerable variation (see Figure 8, Chapter 39). Lowest values, in the range of 1 to 2 bubnoffs (meters/million years), are estimated for upper Eocene to lower Oligocene chalk oozes on the Horizon Ridge. Highest values of 20 to 30 bubnoffs are extrapolated for Middle and Upper Cenozoic chalk oozes on the Caroline Ridge, but most other values are intermediate between these extremes.

\section{Color}

Oozes of this composition are dominantly light in color; typical colors are white, yellowish-white, light yellow, light yellow-brown, pale brown and light gray. In a few cases the appearance of brownish colors could be correlated with increase in siliceous microfossils (for example, in Hole 55.0) or an increase in the amount of volcanogenic material present (for example, in Core 6 of Hole 56.2). A few holes yielded some sediments of this composition with darker colors; for example gray (parts of Holes 47.0, 47.2, 56.2 and 60.0), greenish-gray or grayish-green $(47.0,57.0,57.1)$ and dark gray (47.0, 47.2). Occurrence of these darker shades appears to coincide with the appearance of certain accessory minerals like pyrite or increase in dark volcanic glass fragments.

\section{Sedimentary Structures}

Most of our cores were recovered in a highly disturbed condition (Plate 8, Figures 2, 3 and Plate 10, Figure 3), and in only a few cases were stratification and other structures partly or wholly preserved within these oozes. Although many of the calcareous oozes are strongly mottled, in most cases it was not possible to distinguish organic burrow mottling from drilling disruption and mixing of varicolored layers. Exceptions are in Core 6 of Hole 56.2; Cores 2 through 4, Hole 57.1; and Core 1 and the top part of Core 2, Hole 60. All of these have intervals that are moderately to greatly burrow mottled. Large pyritized burrows occur in Core 1, Hole 47.0 (Plate 8, Figure 1).

Stratification is likewise evident in only a few instances. Core 1 of Hole 47.0, although somewhat disturbed, shows interbedded layers of light gray, dark gray and brown foraminiferal-nannoplankton chalk ooze, with the individual layers being 10 to 35 centimeters thick; this three-fold division is repeated a number of times in 

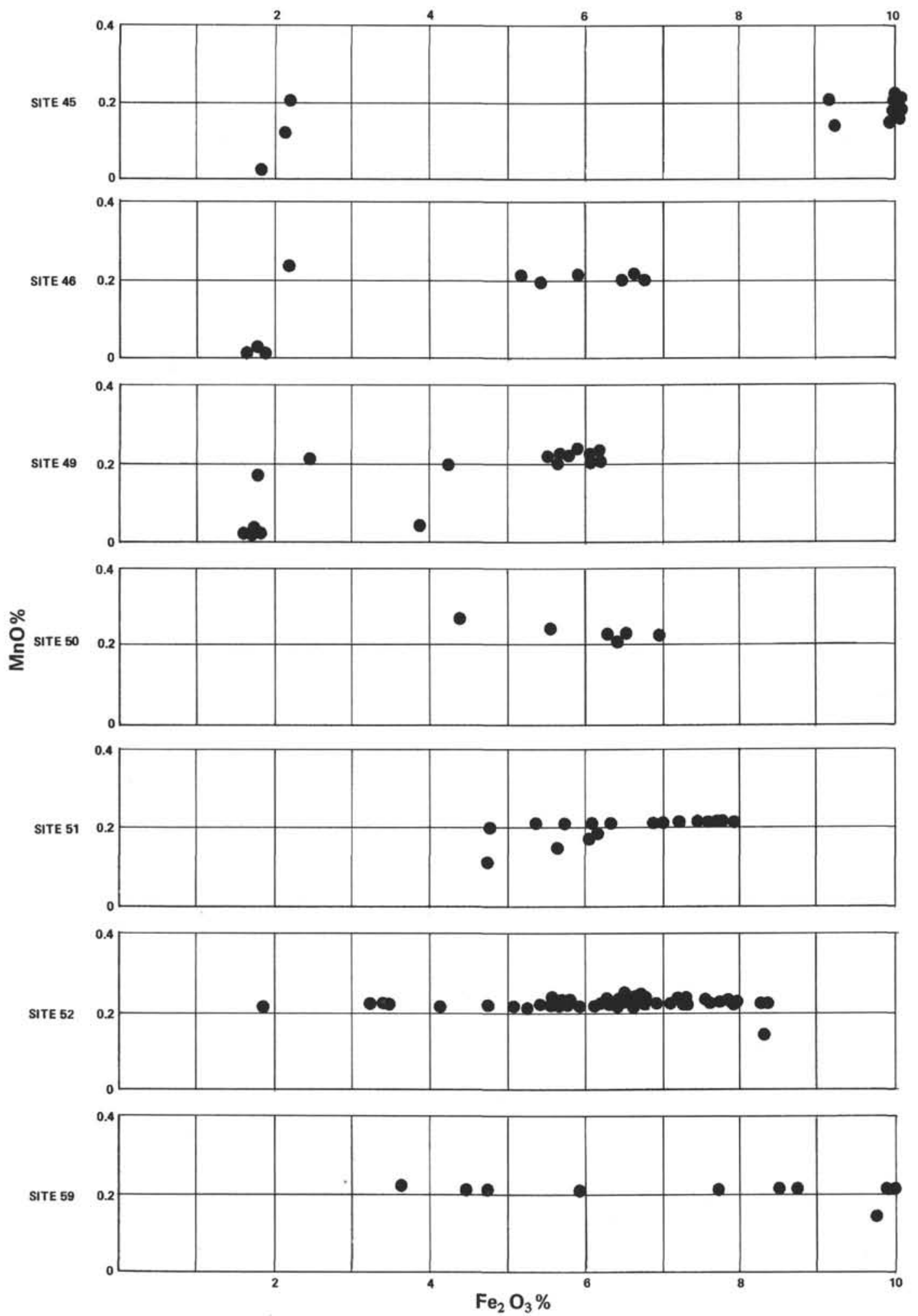

Figure 6. Plots of total iron against manganese in brown clay. 


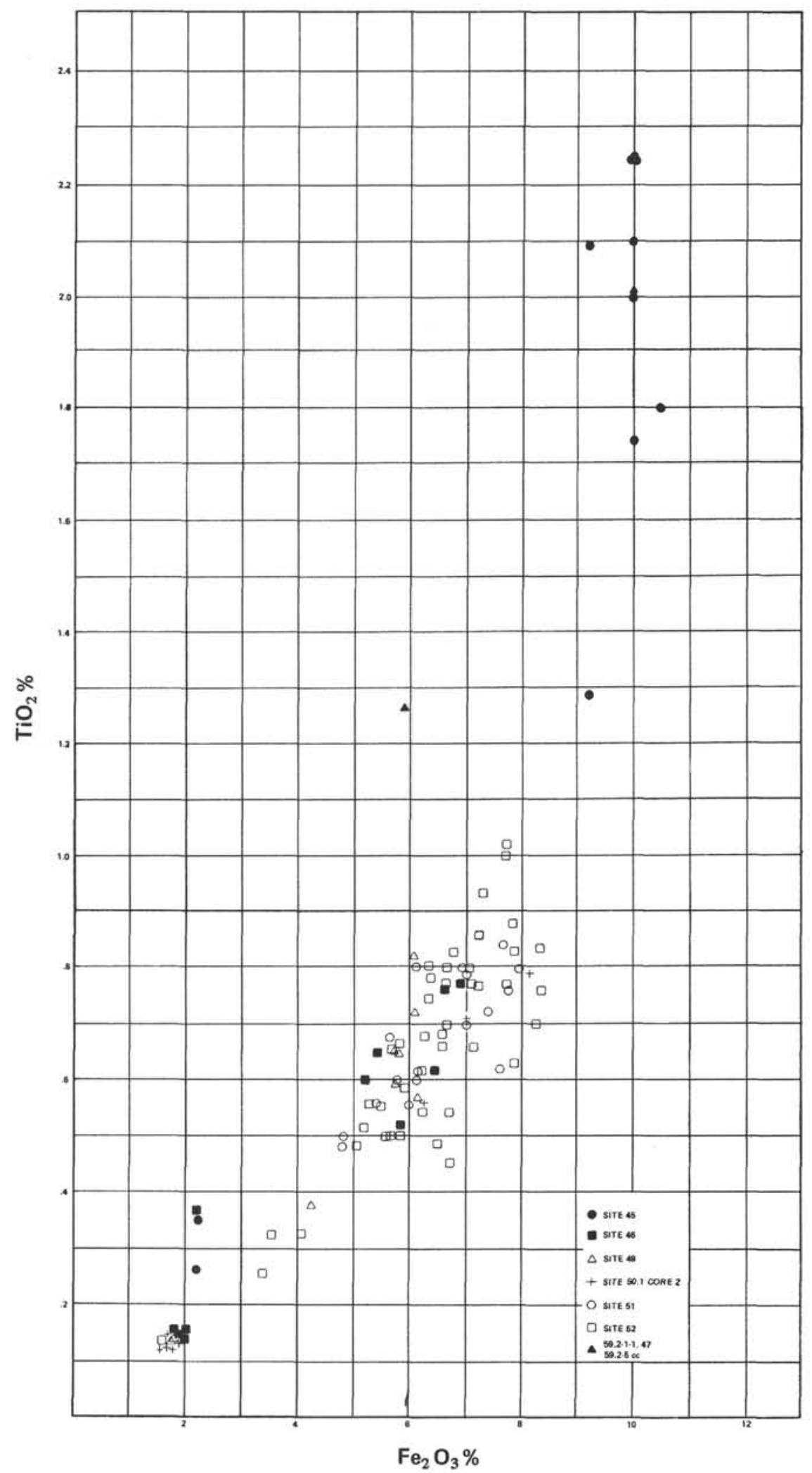

Figure 7. Plots of total iron against $\mathrm{TiO}_{2}$ in brown clay. 

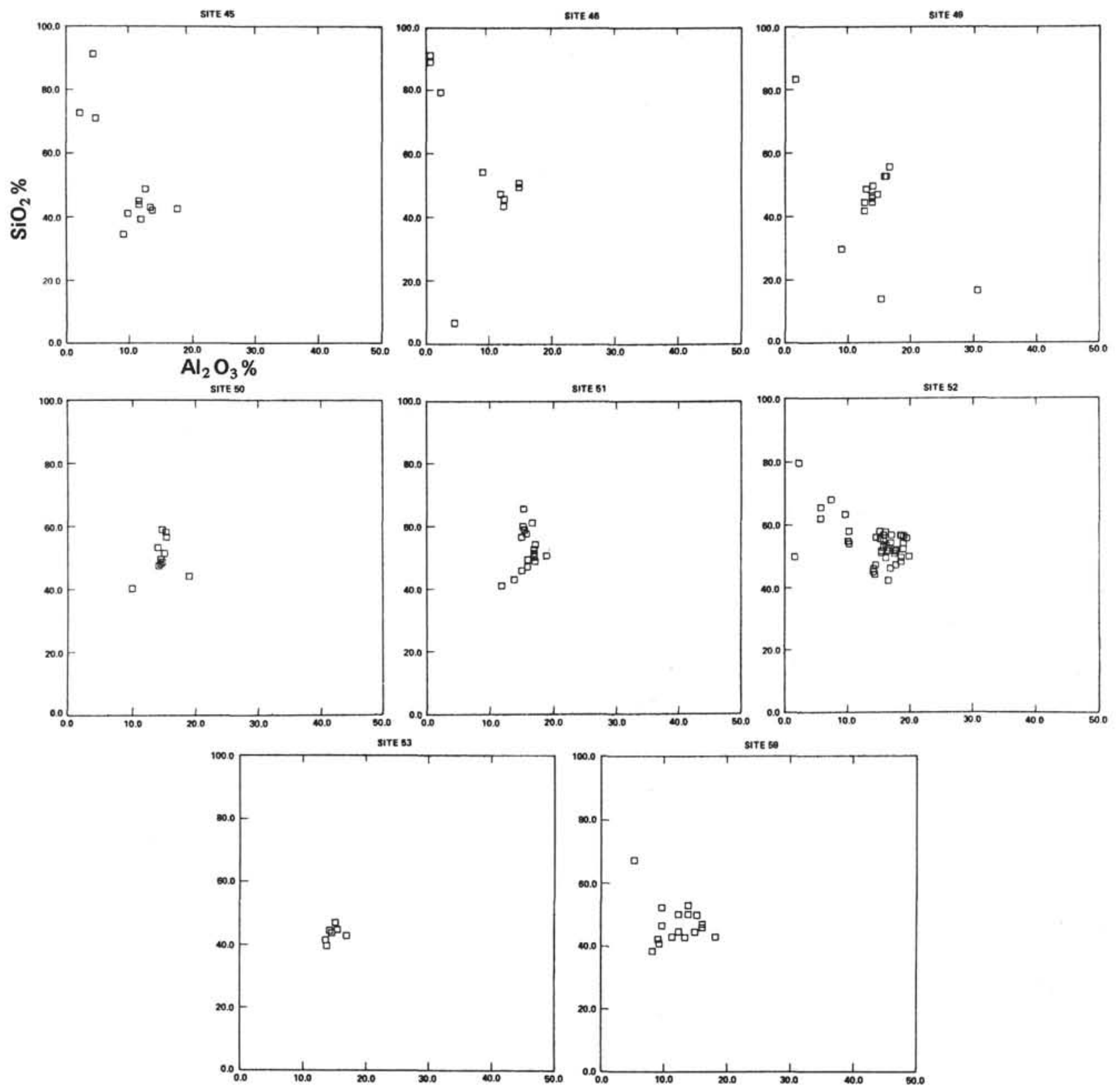

Figure 8. Plots of $\mathrm{Al}_{2} \mathrm{O}_{3}$ against $\mathrm{SiO}_{2}$ in brown clay.

a cyclic pattern. Although not well documented in our studies, the cycles in this Pleistocene sediment may record climatic fluctuations of some type.

A somewhat different type of alternation is evident in the upper Oligocene oozes of Core 1 of Hole 57.0. Here there is a two-fold alternation of: (1) layers, 2 to 5 centimeters thick, of thinly laminated gray, grayishgreen and white nannoplankton chalk and marl oozes that are slightly to moderately burrowed, and (2) thicker layers (10 to 15 centimeters thick) of light gray-green chalk and marl oozes that are heavily burrowed. Interspersed within this sediment are occasional very thin layers of black volcanic ash. At this same site, the upper Oligocene oozes of Cores 2 through 4, Hole 57.1, show similar repetitive bedding, but dark volcanic ash layers figure more prominently in the pattern. A typical "cycle" begins with dark volcanic ash beds that are 5 to 10 centimeters thick, often show size grading becoming finer from bottom to top, and are usually heavily burrowed. This is overlain by marl or chalk ooze in layers that are 10 to 30 centimeters thick and are greatly burrow mottled. Interbedded volcanic ash and calcareous ooze also are prominent in parts of the sediment recovered at Sites 58 and 60. The upper Oligocene sediment of Core 1 , Hole 58.2, consists of 
dominant chalk and marl oozes that are interbedded with lesser amounts of volcanic ash in layers up to 40 centimeters thick; a third element in this core is a layer, 45 to 50 centimeters thick, of gravel-size fragments of limestone and volcanic rock. In Cores 3 through 9, Hole 60, volcanic ash dominates and occurs in thick ( 30 to 50 centimeter) graded beds that are products of turbidity currents or other types of mass flow. Light gray nannoplankton chalk oozes occur in thin layers at the tops of graded ash layers and apparently represent pelagic sedimentation between intervals of current deposition.

Although these observations are very limited, the stratification evident in the pelagic calcareous oozes recovered during Leg 6 seems to fall into two main categories. The first being stratification produced by some fluctuation in supply of pelagic components or in conditions of preservation on the sea floor, perhaps due to climatic variations; examples are in Core 1 , Hole 47.0 , and possibly in Core 1, Hole 57.0. Secondly, there is stratification produced by introduction of volcanic ash, either as falls or mass flows on the bottom, into areas receiving calcareous pelagic sedimentation; examples are recorded in Cores 2 through 4, Hole 57.1, in Core 1 of Hole 58.2, and in Cores 3 through 9 of Hole 60 .

\section{Grain Sizes}

Figure 9 shows the grain size distribution of chalk oozes from sites where recovery of this type of sediment was extensive. Nearly all of these oozes are silty clays or clayey silts, with 25 to 70 per cent silt-size grains, 30 to 70 per cent clay-size and usually less than 15 per cent sand-size material. The predominance of the silt and clay sizes is due to the abundance of nannofossils, which lie mainly in the 2 to 20 micron range. The upper part of the section in Hole 55.0 consists in large part of clayey sands, with up to 60 per cent sandsize grains, mainly tests of planktonic foraminifera.

\section{Mineralogy}

$\mathrm{X}$-ray diffraction studies by Rex (this report) indicate that most of the chalk oozes are pure or nearly pure calcite, although it should be noted that his survey does not record opaline silica or volcanic glass. The major crystalline impurities indicated are clay minerals, quartz and feldspar, but the combined total of these as recorded by X-ray rarely exceeds 30 per cent. The apparent discrepancy of this data with the compositional estimates shown in Figure 2 may stem from the circumstances that: (1) percentages of clay minerals were consistently overestimated in smear slides, (2) percentages of siliceous microfossils and volcanic glass are not recorded by X-ray studies.

\section{Composition}

The triangular diagram shown in Figure 10 portrays the range of compositions based on grain type for the

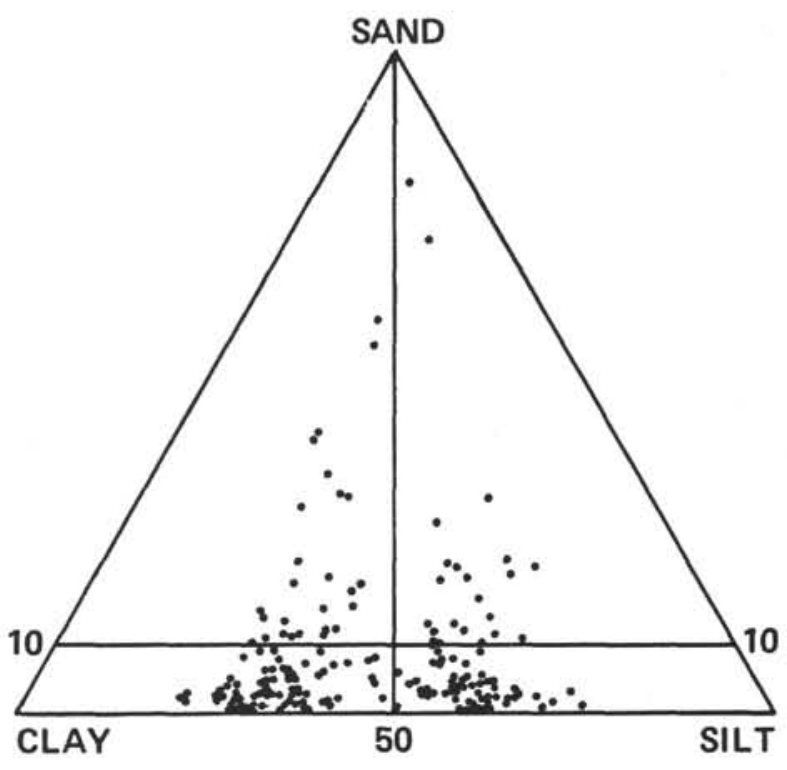

Figure 9. Grain size distribution of pelagic carbon sediments of Sites 44, 47, 48, 55 and 56.

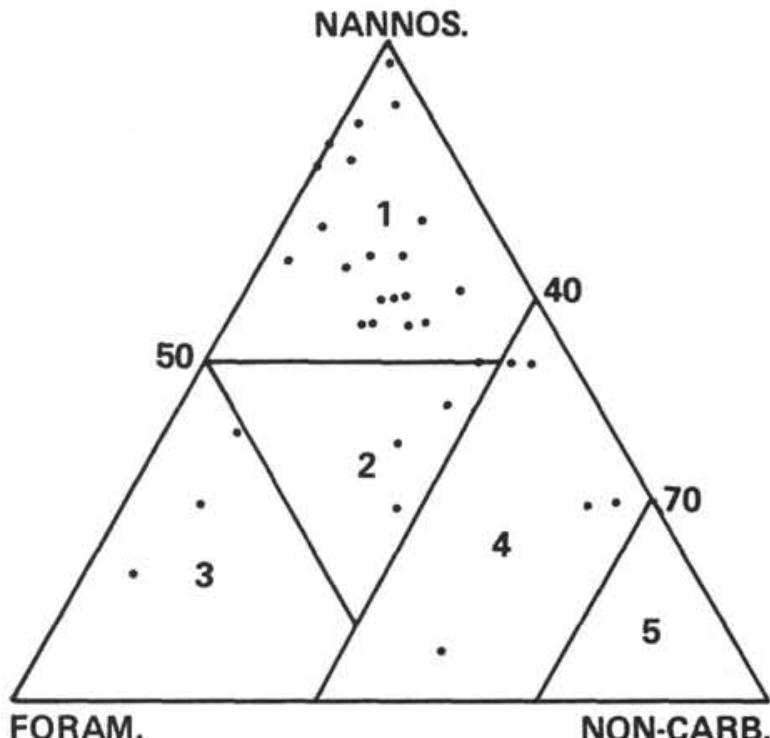

Figure 10. Approximate compositions, by volume, of pelagic calcareous sediments recovered during Leg 6. Based on visual estimations made from smear slides of sediments from Sites 44, 47, 48, 49-51, 55-57 and 60. End members of the ternary diagram are calcareous nannofossils, foraminiferal and calcareous shell material, and non-carbonate material (clay minerals, siliceous microfossils, volcanic glass, etc.). The five fields outlined are: (1) nannoplankton chalk ooze, (2) nannoplankton-foraminiferal chalk ooze, (3) foraminiferal chalk ooze, (4) marl ooze, and (5) brown clay, siliceous ooze, volcanic ash, etc. 
pelagic calcareous oozes encountered on Leg 6 . The points plotted are representative of all sites from which such oozes were recovered (Sites 44, 47, 48, 49-51, 55-57, and 60). They are estimates of volume percentages made from rapid surveys of smear slides, and as such should be taken only as general indications of compositions. The apices selected for gross subdivisions are: calcareous nannoplankton, noncalcareous components (siliceous microfossils, clay minerals, volcanic glass, etc.), and foraminiferal shells and other calcareous skeletal fragments; many of the latter are probably fragments of broken foraminiferal shells, but in some cases a fair percentage of abraded mollusk, ostracod and other invertebrate skeletal material may be included (see Plate 9, Figures 2,3).

This diagram is somewhat arbitrarily divided into a number of categories, among which are marl oozes (calcium carbonate between 30 and 60 per cent; Plate 11 , Figure 4) and chalk oozes (calcium carbonate greater than 60 per cent), following the classification scheme of Olausson (1960). The chalk oozes are further subdivided into nannoplankton chalk oozes (nannoplankton 50 per cent; Plate 11, Figures 1, 2, 3), foraminiferal chalk oozes (foraminifera greater than plus skeletal fragments greater than 50 per cent), and nannoplanktonforaminiferal chalk oozes (both nannoplankton and foraminifera plus skeletal fragments each less than 50 per cent; Plate 12, Figures 1, 2).

As shown in Figure 10, the majority of the pelagic calcareous sediments recovered during Leg 6 are nannoplankton chalk oozes, composed of 50 to 90 per cent nannoplankton. They generally have less than 40 per cent foraminiferal and other shells, and less than 30 per cent of noncalcareous components. Only a relatively small percentage of the sediments could be classified as foraminiferal or nannoplankton-foraminiferal chalk oozes, or marl oozes.

Among the nannoplankton chalk oozes, one variation noted (but not thoroughly documented) is the relative abundances of discoasters and coccoliths. Discoasters appear to be the predominant nannofossil in chalk oozes of late and middle Miocene age (Plate 11, Figure 3 ), whereas coccoliths are more abundant in chalk oozes of other ages (Plate 11, Figures 1, 2). Another age-dependent compositional variation is seen in the chalk oozes of Late Jurassic age encountered at Sites 49 and 50; these sediments lack planktonic foraminifera and are generally very uniform, even-grained oozes composed almost entirely of coccoliths.

Another trend among the chalk oozes is the reciprocal occurrence of siliceous microfossils and chert. Chertbearing chalk oozes contain no siliceous microfossils, and vice versa. Chert was usually, although not invariably, encountered in chalk oozes of early Oligocene (for example, Hole 44.0) or older age, but it does not occur in younger calcareous sediments. Conversely, unaltered siliceous microfossils, with one exception, are present only in late Oligocene or younger chalk oozes. The one exception is the presence of very rare siliceous microfossils in the Paleocene chalk ooze of Core 10, Hole 47.2. The overall trend suggests diagenetic solution of siliceous microfossils in chalk oozes of pre-late Oligocene age and local reprecipitation of the silica as chert; and, the exact composition of these oozes is, thus, in part a function of age and diagenesis. It should be noted, however, that in certain instances relatively young chalk oozes lack siliceous microfossils or have them in only very small amounts. An example of this is found in Hole 55.0; Cores 1 through 7 contain Pleistocene to middle Miocene oozes with virtually no siliceous microfossils, whereas Cores 8 through 14 have middle Miocene to upper Oligocene oozes in which siliceous microfossils are common. In this case the dearth of siliceous microfossils in the younger oozes is more likely due to their scarcity in the original sediment rather than to wholesale diagenetic removal following burial. This scarcity may be related in some cases to preferential dissolution of siliceous microfossils at shallower depths (Berger, 1968; also, see discussion by Kling in the biostratigraphy synthesis of this report).

The marl oozes recovered during Leg 6 are essentially impure nannoplankton chalk oozes; they include those with abundant clay minerals and iron oxides, siliceous microfossils, or volcanic glass (Plate 6, Figure 3 and Plate 11, Figures 4, 5). Marl oozes, in generally small amounts, were recovered in Holes 49.0, 49.1, 50.1, $56.2,57.1,58.1$ and 58.2. Nearly all of them are either of Pleistocene or late Oligocene age. The type and amount of noncalcareous impurities appears in part related to the topographic and geographic setting of the depositional site. Those marl oozes characterized by abundant clay minerals, iron oxides or siliceous microfossils are from areas that lie near the compensation depth for calcium carbonate (Sites 49, 50 and 58); typically they are associated with deep abyssal deposits like brown clays and siliceous oozes. Among these marl oozes it is noteworthy that nannofossils form the bulk of the calcium carbonate present, whereas foraminifera and other calcareous skeletal elements are very rare. This probably reflects the greater resistivity to solution of the nannoplankton at water depths approaching the compensation level.

A second group of marl oozes is characterized by abundant volcanogenic material in addition to siliceous microfossils and clay minerals. These oozes were recovered from areas near volcanic island arcs (Sites 56 and 57) and are typically interbedded with volcanic ash layers. 
A somewhat unique zeolitic marl ooze occurs along the unconformable surface separating upper Miocene and lower Eocene chalk oozes on the Shatsky Rise. This sediment, recovered in the core catcher of Core 6, Hole 47.2, is a highly burrowed, light brown marl ooze containing abundant fish debris, thick-shelled foraminifera, and large, complexly twinned phillipsite crystals that are plastered with coccoliths (Plate 19, Figures 1, 2 ) and show prominent zoning (Plate 7, Figure 1). The unusually large size of these phillipsite crystals (up to 500 microns long) suggest they formed through long continued growth, perhaps at the sediment-water interface during a considerable period of nondeposition.

\section{Altered Chalk Oozes}

Except for localized secondary silicification, diagenetic alteration is not pronounced in most of the chalk oozes recovered, although minor overgrowths of secondary calcite on nannofossils and minor solution effects were noted in a few cases, for example in Core 10 from Hole 56.2 (see discussion of preservation in the biostratigraphy synthesis).

The only extensively altered, unlithified calcareous ooze found is in Cores 4 to 6 of Hole 53.0. In the smear slide (Plate 11, Figure 5) this sediment appears as a mass of fine-grained, anhedral calcite crystals in which are dispersed occasional nannofossils. The anhedral calcite crystals lie mostly in the 2 to 20 micron size range and typically have very irregular shapes. In smear slides they appear to make up some 80 to 90 per cent of the sediment. Under the electron microscope, however, nannofossils appear considerably more abundant although altered to varying degrees. A common form of alteration seems to be the growth of small crystals of secondary calcite (?) on coccoliths (Plate 25, Figures 1, 3). In addition, the boundaries between the tiny coccolith platelets often are indistinct (Plate 25, Figure 2) suggesting the onset of recrystallization in which the multicrystal coccoliths are reformed into a few crystals or a single crystal. Secondary calcite occurs within void spaces in the centers of some coccoliths, and the margins of some coccoliths show evidence of secondary overgrowths (Plate 25, Figure 1). Discoasters in this ooze commonly show indications of extensive solution around their margins, as well as growth of small secondary crystals on plate surfaces (Plate 25, Figure 3). All of these effects tend to reduce the visibility of nannofossils with the optical microscope, and probably account for the apparent paucity of observable nannofossils in smear slides.

In addition to the altered nannofossils, the electron microscopic observations also show numerous grains of anhedral calcite that apparently contain numerous inclusions and secondary overgrowths (Plate 25, Figure 4). These may in part represent completely recrystallized nannofossils, in part void-filling cement from a slightly lithified chalk ooze; as noted in the Site Summary for Site 53, this particular ooze could have been produced through disruption of lithified marls and oozes during coring.

The observations cited above suggest this material is largely a partly recrystallized nannoplankton ooze, perhaps, as noted, weakly lithified. Strictly diagenetic processes seem inadequate as an explanation since a number of workers (Robertson, 1965; Minoura and Honjo, 1969) report that experimental recrystallization or lithification of coccolith oozes could not be attained, even at pressures of up to 1000 bars and temperatures up to $400^{\circ} \mathrm{C}$. Minoura and Honjo (1969), however, illustrate growth of small secondary crystals of calcite on coccolith plate surfaces, a phenomenon very similar to that observed in the ooze under discussion. The coccoliths in the Minoura-Honjo experiment were held in an hydrothermal environment for seven days at $300^{\circ} \mathrm{C}$ and 90 atmospheres pressure.

In lieu of further evidence that might come from isotopic studies of this ooze, it is tentatively concluded that the recrystallization evident is the product of thermal metamorphism associated with submarine volcanic flows or hypabyssal intrusions.

\section{Carbonate Silts, Sands and Gravels}

Calcareous sediments with components other than skeletons of planktonic organisms were rarely observed during Leg 6. The most notable exceptions were encountered at Site 58 . Here, the catcher sample for Core 1, Hole 58.0, recovered subangular to subrounded gravel to coarse sand-size debris composed of volcanogenic grains, limestone, and abraded skeletal fragments of shallow-water organisms, such as, corals, echinoids, mollusks and benthonic foraminifera. At this same site, Core 1 of Hole 58.1 contained-interbedded in Pleistocene pelagic oozes-an 80-centimeter layer of sandy silt containing abraded pelecypods, echinoderms and benthonic foraminifera. Likewise, upper Oligocene pelagic oozes of Core 1 , Hole 58.2, contain a 50-centimeter layer of gravel composed of angular to rounded clasts of volcanic rocks and limestone. As noted in the Site Summary, these coarser materials most likely were redeposited from adjacent atolls and shallow marine areas in the Caroline Islands.

A frequently encountered, although minor component of all the chalk oozes recovered during Leg 6 is silt- to sand-size grains of anhedral calcite (for example, in the chalk oozes of Sites $44,47,48,50$, and 55 through 58). As noted repeatedly in the individual Site Summaries, it is often difficult to determine whether this material is of authigenic origin or whether it is finely abraded skeletal material (for example, of mollusks, foraminifera) or a combination of both. In some cases this material occurs in bundles of prismatic carbonate crystals 
that are almost certainly fragments of mollusk shells, but such grains may be mixed with other anhedral grains of indeterminate origin.

\section{LITHIFIED AND COMPACTED CARBONATE OOZES SITES 45, 53, 54 and 57}

(R. E. G.)

Despite the abundance of carbonate ooze that was cored, lithified or consolidated carbonate sediments were rarely encountered on Leg 6. Small amounts of limestone were retrieved from Sites 45 and 54, but limestone in substantial quantity was found only at Site 53. In addition, compacted and somewhat consolidated chalk ooze was recovered immediately above basement at Site 57.

\section{Site 45}

A single piece of light gray, friable limestone of Cenomanian age was recovered in the core catcher sample of Core 3, Hole 45.1. This is a micritic limestone containing very poorly preserved remains of planktonic foraminifera and Radiolaria (Plate 23, Figures 1, 2). These microfossils generally occur as either empty molds or as molds infilled by secondary calcite or chalcedonic quartz. X-ray diffraction indicates the presence of low magnesian calcite, cristobalite, quartz and aragonite, in approximate order of abundance.

The scanning electron micrographs of Plates 27 and 28 shed some light on the distribution of these minerals in the rock. The matrix contains abundant, well-preserved calcitic coccoliths as well as blocky subhedral grains that are presumably calcite crystals of secondary origin (Plate 27, Figure 2). Secondary calcite also occurs as subequant crystals growing from the interior walls of foraminiferal chambers (Plate 28, Figure 3). Aragonite seems to occur mainly as acicular crystals arranged in hemispherical clusters that also line interior walls of microfossils but precipitated later than the secondary calcite (Plate 27, Figures 3, 4, and Plate 28, Figure 2). Location of the cristobalite was not determinable by either optical or electron microscopy, and this mineral is presumably lodged mainly in the fine-grained matrix.

The data from this one sample are insufficient to suggest an origin for the lithification, but precipitation of secondary calcite, aragonite and cristobalite seem to be involved.

\section{Site 53}

The only extensive recovery of limestone on Leg 6 was from Cores 4 through 8 of Hole 53.0. These are mainly friable, reddish-brown to yellowish-brown limestones that overlie and are interlayered with basaltic basement rocks, and may owe their lithification to thermal alteration.

\section{Relations Between Limestones and Volcanic Rocks}

These are discussed extensively in the site report for Site 53, and only the salient points are recapitulated here. Lithified and altered carbonate sediments are found below a subbottom depth of 174 meters at this site. About 21 meters of altered reddish-brown chalk ooze and limestone lie above basaltic basement rock. Limestone also occurs within the basalt as thin layers, small veins and clasts. Clasts of basalt in turn are also found in some of the limestones.

\section{Megascopic Description of Limestones}

Most of the limestones are breccias (see Plate 20) in which angular to subangular clasts of reddish-brown limestone are cemented in a fine-grained matrix of pale reddish-brown limestone that has indications of flow layering (Plate 20, Figure 4). In some cases the breccia clasts are partly or completely rimmed by white sparry calcite (Plate 20, Figures 1,4). Small open vugs are common in both the clasts and matrix material (Plate 20, Figures 1, 4).

\section{Altered Nannoplankton Chalk Oozes}

These lie above well-lithified limestones and are described more fully in the summary discussion of carbonate sediments. They are reddish-brown and consist of mixtures of nannofossils and anhedral calcite crystals (Plate 11, Figure 5). Percentage of the former decreased downward in the hole, while the latter increase. Electron micrographs of this sediment (Plate 25, Figures 14) show nannofossils in varying stages of alteration as well as anhedral grains of probable secondary origin (Plate 25, Figure 4). Among the textural changes noted in the nannofossils are growth of secondary crystals on coccoliths (Plate 25, Figure 1), loss of definition between plates (Plate 25, Figures 2,3) and suggestions of solution around the margins (Plate 25, Figure 3). Although this ooze was recovered in cores as soft sediment, it may have been derived from weakly lithified sediment that was disrupted during coring. As noted, diagenetic processes seem inadequate to account for the degree of alteration present; more likely it is the result of thermal metamorphism accompanying igneous activity.

\section{Mineralogy and Microscopic Description of Limestones}

A limited amount of X-ray diffraction work on the limestones reveals the presence of low magnesian calcite, clay minerals and minor amounts of cristobalite and quartz.

In thin sections the breccia clasts of the limestones are seen to be composed in turn of subrounded to subangular bodies of limestone that are cemented in a mixture of white sparry calcite and small particles of limestone (Plate 23, Figures 5, 6). The limestones have very poorly preserved calcitic molds of microfossils of indeterminate 
origin; these are dispersed in a fine-grained calcareous matrix containing scattered specks and aggregations of iron oxides (Plate 24, Figure 2). Some of the limestones are extensively recrystallized (Plate 24, Figure 3 ).

Recrystallization of the matrix is more evident under the electron microscope, as seen in Plate 25, Figures 5 and 6, Plate 26 and Plate 27, Figure 1. These electron micrographs show abundant coccoliths with different degrees of recrystallization and replacement by anhedral to euhedral crystals of calcite. Recrystallization of individual coccoliths is most commonly evident by the fusing of plate boundaries (Plate 25, Figure 6 and Plate 26, Figure 1), in much the same manner as in the overlying, partly recrystallized chalk oozes (Plate 25, Figures 1, 2, 3). Most of the surviving coccoliths are embayed and engulfed around their margins by anhedral calcite crystals that have curved and irregular grain boundaries (Plate 25, Figures 5, 6; Plate 26, Figures 1, $2,5)$. Total replacement of coccoliths leads to a mosaic of such grains (Plate 26, Figure 6). Subhedral to euhedral calcite crystals appear to be products of later stages of recrystallization as they replace both coccoliths and anhedral calcite crystals (Plate 26, Figures 3, 4).

\section{Veins}

Some of the limestone and basalt at this site is laced by networks of veins containing calcite and other minerals (Plate 24, Figures 4, 5). This calcite is clearly void-filling material comprising prismatic crystals oriented with long dimensions perpendicular to the vein wall; in some cases unfilled void space remains near the center of the vein (Plate 24, Figure 4). The vein calcite commonly shows closely spaced concentric growth lines (Plate 24, Figure 4), and much of it is cloudy and brownish due to abundant tiny inclusions. In many instances vein filling apparently occurred in multiple episodes producing alternating layers of clear and cloudy calcite (Plate 24, Figure 5).

Other materials found in veins include fine-grained limestone, amorphous silica (Plate 24, Figure 6) and euhedral zeolite crystals (Plate 24, Figures 1, 6). Although the latter could not be isolated for X-ray diffraction, they closely resemble the harmotome crystals identified and described by Morgenstern (1967) in lithified, tuffaceous deep-sea deposits; their very low birefringence $(0.004$ to 0.005$)$ and the presence of common four-membered twins are consonant with this identification. Morgenstern (1967) presented evidence that the harmotome in the tuffaceous mudstones he studied formed through low temperature, diagenetic alteration of palagonite. In contrast, the zeolites at Site 53 line vein walls and are probably of hydrothermal origin.

\footnotetext{
${ }^{1}$ The transmission electron micrographs of Plate 25, Figures 5 and 6 , and Plate 26 are of polished and etched surfaces replicated by the two-stage method (Honjo and Fischer, 1965).
}

\section{Origin}

As indicated in the discussion of Site 53, these limestones and recrystallized carbonate oozes are most likely nannoplankton chalk oozes that were thermally metamorphosed during Tertiary extrusion and intrusion of basaltic magmas. Consequences of this metamorphism are seen on a microscopic scale in the recrystallization of microfossils and nannofossils, and in the growth of secondary calcite crystals. Both recrystallization and secondary growth are part and parcel of the lithification process.

On a megascopic scale, the extensive brecciation evident in these rocks is probably in part a result of dewatering, lithification and shrinkage of chalk ooze under thermal stress, in part due to mechanical disruption of sedimentary material during igneous intrusion and extrusion. The latter process must have produced a great deal of mobility in both lithified and unlithified carbonates, resulting in such features as clasts of limestone within basalt, flowage of breccia fragments, and flowage of unlithified calcareous ooze between breccia clasts and into open cracks within the basalt (Plate 20, Figures 1, 2, 4 and Plate 24, Figure 6).

Chemical changes accompanying the metamorphism produced sparry calcite cement (Plate 23, Figure 5), rims of sparry calcite around clasts (Plate 20, Figures 1,4 ), and veins of sparry calcite (Plate 24, Figures 5, 6) as well as veins bearing zeolites and amorphous silica (Plate 24, Figures 1,6). Whether these void-filling materials were derived mainly from volatile phases of the magmas, or by partial solution and reprecipitation of carbonate ooze is not known. The common iron oxide granules (Plate 24, Figures 2, 3) and more finely disseminated iron oxides that give the rocks their reddish colors may likewise represent ferric compounds derived either from magmas, or from mobilization and redistribution of sedimentary iron oxides.

The two major types of void-filling materials are sparry calcite and fine-grained limestone, but some voids remain incompletely filled. That void-filling occurred in several episodes is suggested by alternating layers of different varieties of vein calcite and other materials (Plate 24, Figures 5, 6). This is even more strongly indicated by features like those illustrated in Plate 20 , Figures 1 and 4, where sparry calcite grew outward from the margins of breccia clasts into interparticle void space that was subsequently filled by "internally resedimented" carbonate ooze.

\section{Site 54}

A single small clast of light brown limestone was found enclosed within basaltic basement rock in Core 8 of Hole 54.0. Although not studied in detail, it is most likely a fragment of lithified chalk ooze that was 
engulfed in extrusive or intrusive magma, under circumstances similar to those at Site 53. In addition the basalts of Site 54 are cut by networks of sparry calcite veins (Plate 14, Figure 6 and Plate 21, Figure 3).

\section{Site 57}

Although not lithified, the laminated, late Oligocene chalk ooze immediately above basement rock at this site is compacted and coherent (Plate 22). Thin sections of this sediment (Plate 23, Figures 3,4) show planktonic foraminifera dispersed through a coccolith-rich matrix. No void-filling minerals (sparry calcite or chalcedonic quartz) have been precipitated in foraminiferal chambers which remain empty or are partly to completely filled by ooze. The high degree of compaction in this ooze is probably due to the fact that it lies immediately above hard basement rock and beneath about 328 meters of overburden.

\section{SILICEOUS SEDIMENTS}

$$
\text { (R. E. G.) }
$$

Siliceous oozes of organic origin were recovered at six sites on Leg 6 (Sites 49, 50, 51, 53 and 59). Following the definitions of Olausson (1960), pelagic sediments are defined as siliceous oozes in this report if they contain more than 30 per cent of siliceous organisms and less than 30 per cent of calcium carbonate of all types. Summary data on the siliceous oozes found during Leg 6 are shown in Table 5 , and Figure 10 portrays some estimates of composition based on grain types for selected samples. Ages of siliceous sediments recovered on Leg 6 range from Quaternary to late Oligocene, and they all occur at sites located in very deep water, either near or below the present compensation depth for calcium carbonate.

\section{Color and Stratification}

Colors are most typically brown or light shades of brown (very pale brown, light gray brown or yellowishbrown). Only the lower Miocene to upper Oligocene radiolarian oozes in Cores 1 to 4 of Hole 59.2 are dark brown or dark yellowish-brown.

Characteristically these oozes occur as rather thin layers, a few centimeters to a few decimeters thick, interlayered with brown clays, volcanic ash or, in a few cases, with nannoplankton marl or chalk ooze. The thickest single intervals found are the 8 meters of upper Miocene radiolarian ooze in Core 1 of Hole 53.2, and the 10.5 meters of upper Oligocene to lower Miocene radiolarianspicule ooze of Cores 1 to 4 , Hole 59.2.

\section{Grain Size}

Grain size distribution of siliceous oozes that were analyzed are shown in Figure 11. These sediments are poorly sorted silty clays, clayey silts and sandy silts. The radiolarian ooze of Hole 53.2 is the coarsest and most poorly sorted siliceous sediment recovered, largely due to the abundance of volcanic glass fragments.

\section{Mineralogy}

Although the X-ray diffraction studies of Rex (this volume) do not record the presence of opaline skeletal material or of volcanic glass, they do shed some light on the relative abundances of crystalline materials. Quartz and clay minerals are the most abundant of these with three exceptions. Calcite dominates in Core 1 , Hole 50.1, where it forms up to 87 per cent of the crystalline fraction; it also dominates in the siliceous oozes of Hole 58.2 where it composes up to 45 per cent of the same fraction. In both cases this is due to the presence of abundant nannofossils. The third exception is found in the siliceous ooze of Core 1, Hole 53.2, where plagioclase of probable volcanic origin (up to 90 per cent) dominates other crystalline components. Plagioclase is also an important though subordinant component in all of the other siliceous oozes recovered and is likewise probably volcanogenic.

\section{Composition}

Only the Quaternary diatom oozes of Holes 58.1 and 59.1, composed almost entirely of the frustules of Ethmodiscus rex (Plate 11, Figure 6), are essentially pure siliceous deposits (Figure 10). In addition to the dominant diatoms, they contain very small amounts of Radiolaria, sponge spicules, volcanic glass and zeolites.

In most other cases these oozes are characterized by high percentages of non-opaline components, and a glance at Plate 2, Figures 3, 4 will convey better than words an impression of impure, poorly sorted deposits. Most are classified as either radiolarian, radiolariandiatom or radiolarian-spicule oozes (Table 5) whose estimated compositional ranges are 40 to 60 per cent siliceous microfossils and 40 to 60 per cent of other components (Figure 12). Most prominent among the latter are quartz, clay minerals, plagioclase and volcanic glass shards; lesser impurities include iron oxide and opaque grains. In some cases the siliceous oozes seem gradational to brown clays or volcanic ashes (Plate 12, Figure 6).

Among the siliceous organisms, Radiolaria normally dominate, sponge spicules are usually second in abundance, and silicoflagellates are very minor components. Diatoms are present either in very small amounts or are absent, but exceptions to this are the Quaternary Ethmodiscus oozes already noted and parts of the Pleistocene siliceous oozes of Holes 50.1 and 51.1 where diatoms sometimes equal or exceed Radiolaria in abundance. Diatoms are exceedingly rare in most prePleistocene siliceous oozes recovered. Sponge spicules occasionally attain abundances equal to or exceeding that of Radiolaria, as in parts of the radiolarian-spicule oozes of Holes 58.2 and 59.2. 


\section{PLATE 11}

Smear Slides of Calcareous and Siliceous Oozes from Leg 6

Figure 1 Sample 48.2-2-4, $60 \mathrm{~cm}$ (plain light, $\times$ 292):

Upper Cretaceous (Maestrichtian).

Nannoplankton chalk ooze composed dominantly of coccoliths and coccolith fragments.

Figure 2 Sample 44-4-2, $150 \mathrm{~cm}$ (plain light, $X 292$ ):

Middle Eocene.

Nannoplankton chalk ooze composed of mixture of discoasters and coccoliths of varying size.

Figure 3 Sample 55.0-4-2, 145-150 cm (plain light, $X 292$ ):

Upper Miocene.

Nannoplankton chalk ooze composed dominantly of discoasters.

Figure 4 Sample 49.0-1-4, $20 \mathrm{~cm}$ (plain light, $\times 146$ ):

Pleistocene.

Nannoplankton marl ooze composed of poorly sorted mixture of discoasters, coccoliths, volcanic glass shards and iron-oxide granules.

Figure 5 Center bit sample between Cores 4 and 5, Hole 53.0 (plain light, $\times 146$ ):

Mass of apparently anhedral calcite grains. Electron microscopic studies of this calcareous sediment shows altered nannofossils to be very abundant (see Plate 25, Figures 1-4).

Figure 6 Sample 58.1-1-1, $105 \mathrm{~cm}$ (plain light, $\times 117$ ):

Pleistocene.

Diatom ooze composed largely of frustules of Ethmodiscus rex. 

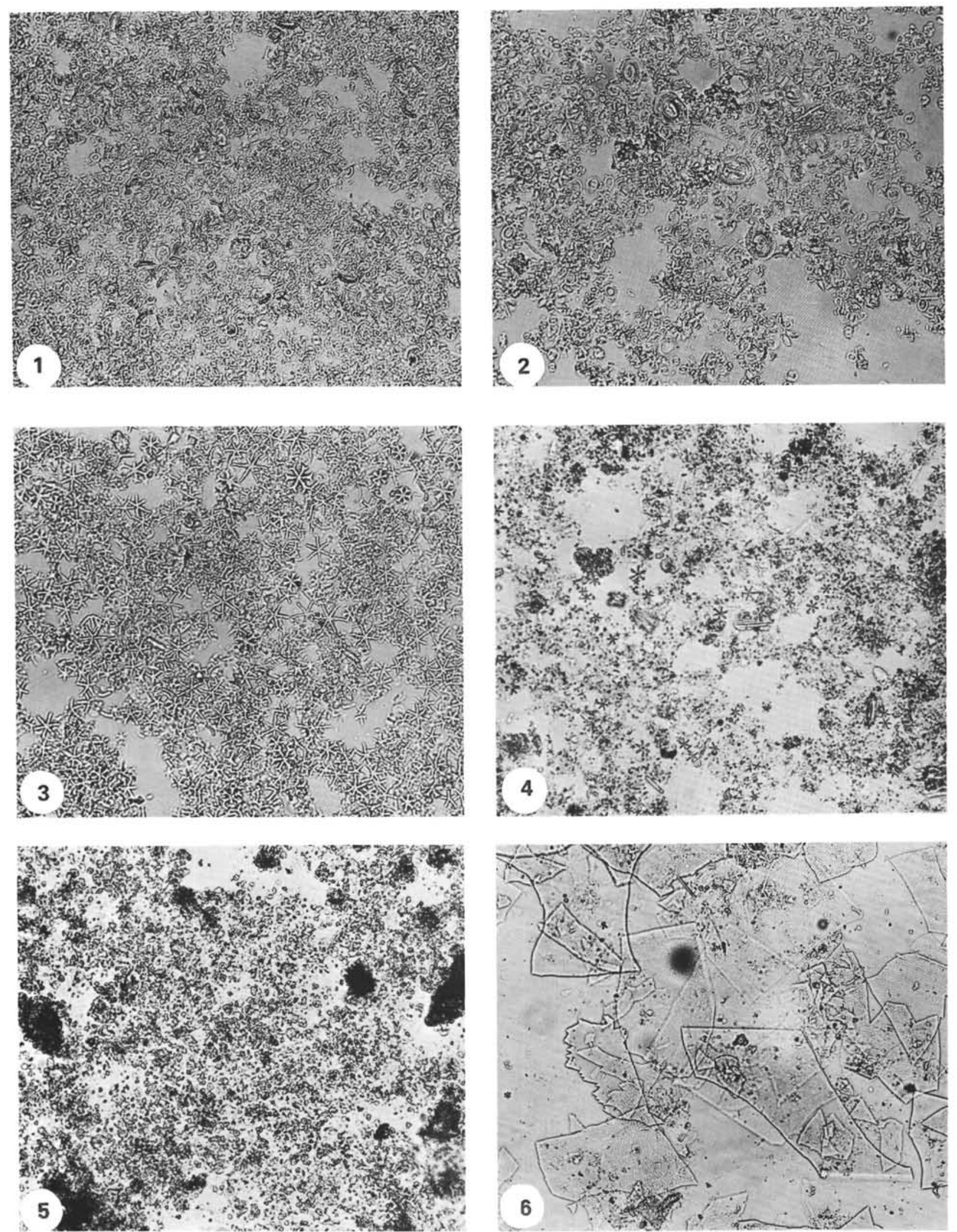
PLATE 12

Smear Slides of Calcareous and Siliceous Oozes from Leg 6

Figure 1 Sample 55.0-1-2, $20 \mathrm{~cm}$ (plain light, $X$ 117):

Pleistocene.

Foraminiferal-nannoplankton chalk ooze composed largely of planktonic foraminifera tests. Fragmentation of many shells occurred during slide preparation.

Figure $2 \quad$ Same as $1, \times 37$.

Figure 3 Sample 59.2-2-2, $20 \mathrm{~cm}$ (plain light, $X$ 47):

Poorly sorted lower Miocene radiolarian-sponge spicule ooze containing a considerable admixture of silicate grains, volcanic glass shards, fine-grained iron oxide granules and clay minerals.

Figure 4 Sample 59.2-4-1, $140 \mathrm{~cm}$ (plain light, $\times$ 47):

Very poorly sorted upper Oligocene radiolarian ooze containing abundant altered volcanic rock fragments, zeolites and silicate grains, clay minerals and finegrained iron oxides.

Figure 5 Sample 54.0-1-2, $80 \mathrm{~cm}$ (plain light, $\times 117$ ):

Poorly sorted middle Miocene calcareous and siliceous volcanic ash containing mixture of glass shards, nannofossils, planktonic foraminifera, radiolarian tests, sponge spicules, silicate grains and clay minerals.

Figure 6 Sample 58.2-1-6, $80 \mathrm{~cm}$ (plain light, $\times 146$ ):

Poorly sorted, radiolarian-spicule ooze of late Oligocene age. In addition to well-preserved sponge spicules and radiolarian tests, this sample contains a large admix ture of calcareous nannofossils, glass shards and altered volcanic rock fragments, and silicate grains. 


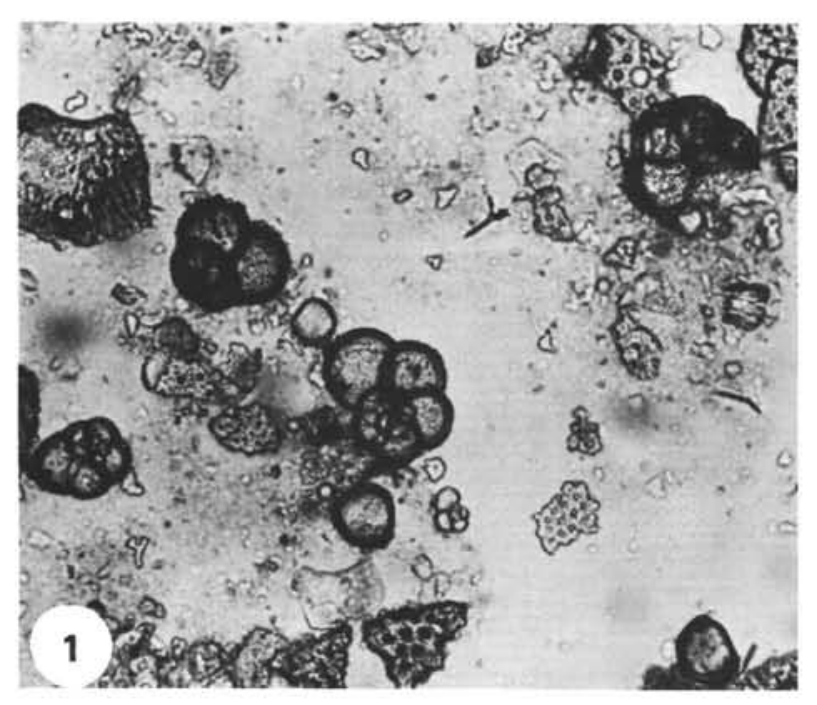

7 .

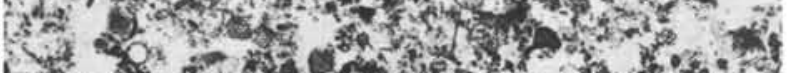

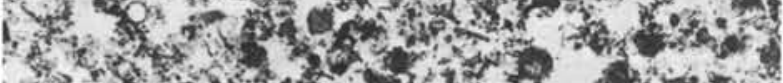

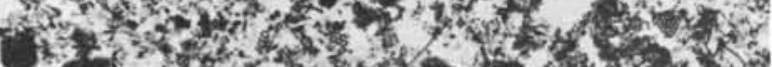

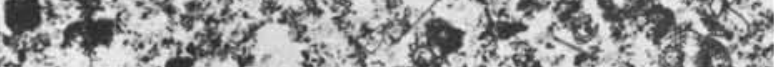

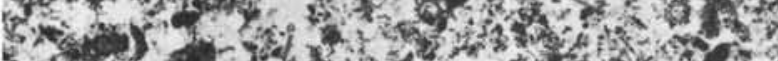
IX)

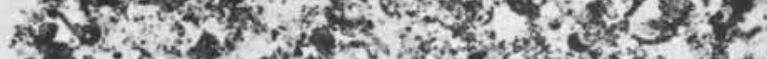
C. Ho

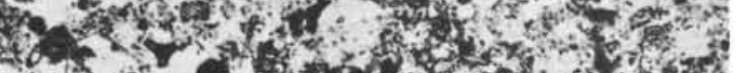
H.

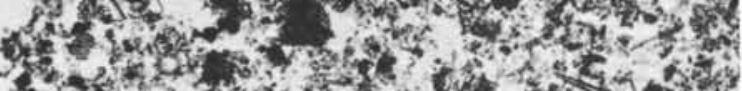

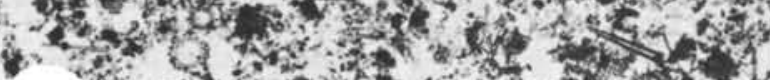
3 . 3 .

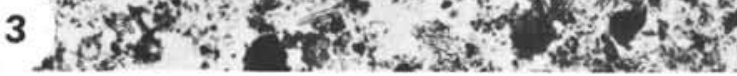

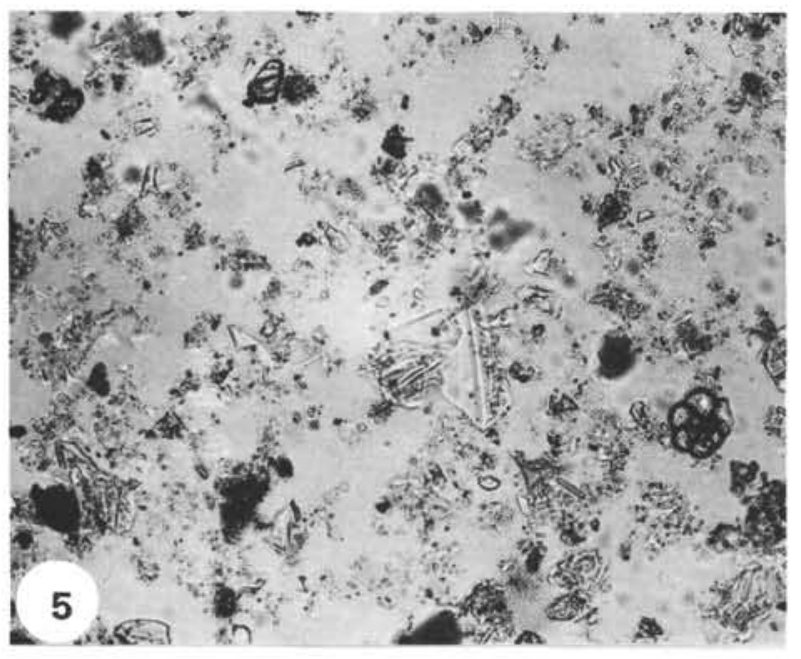

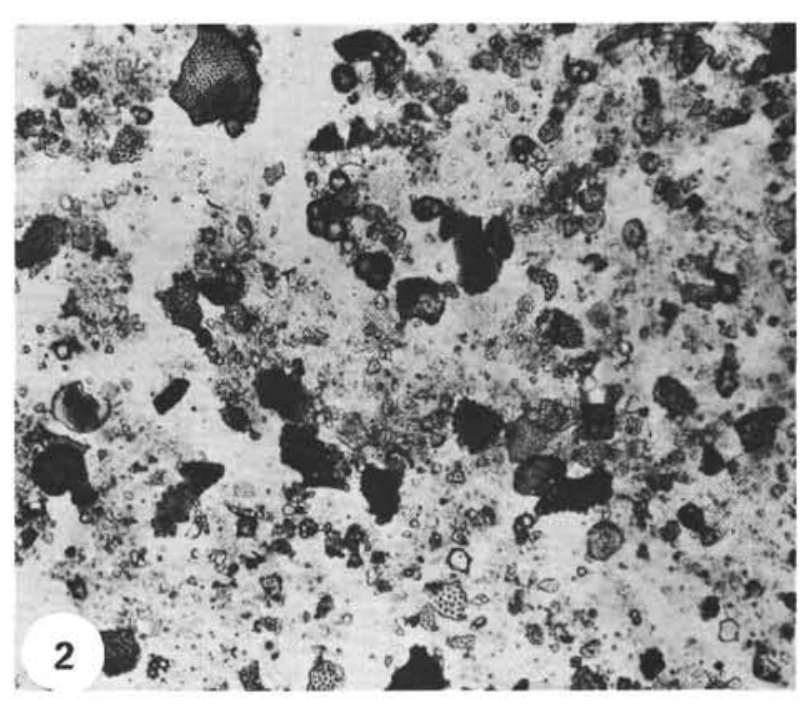

4. -

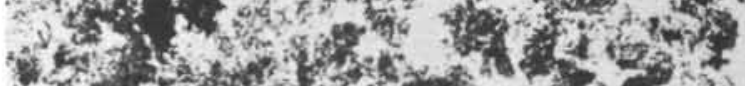

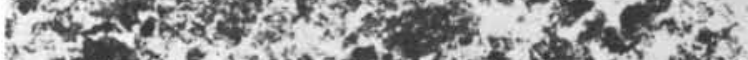
2.

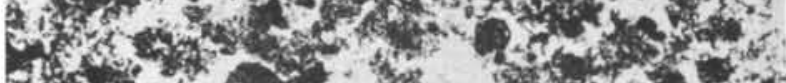
140 - a

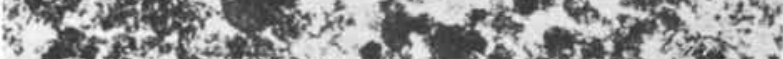

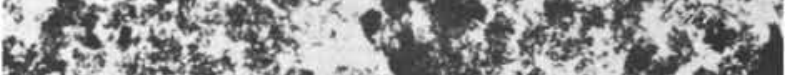

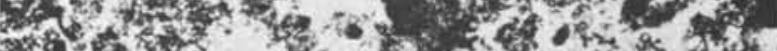

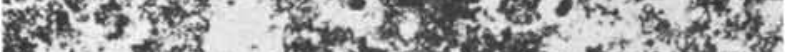

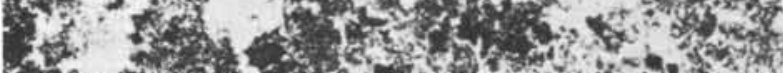

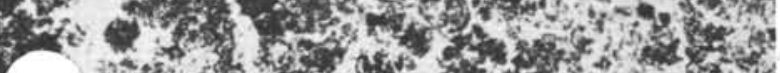

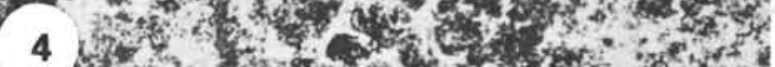

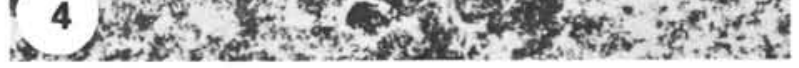

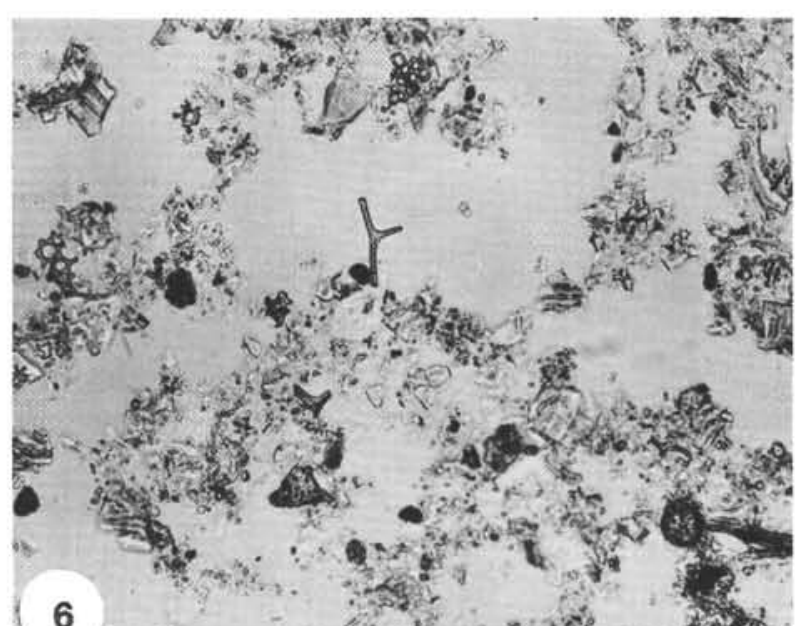

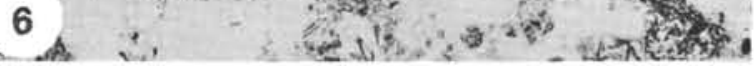




\section{PLATE 13}

Photomicrographs of Cherts and Radiolarian Mudstones

Figure 1 Sample 46.0-1-6 (plain light, $\times 29$ ):

Banded, slightly friable radiolarian mudstone. Very poorly preserved radiolarians in matrix of finegrained silica and clay minerals.

Figure 2 Same as Figure 1 (cross-polarized light):

Radiolarian molds in central band are largely hollow, those above and below filled with secondary chalcedonic quartz. Many of the molds in both types of layers have a thin outer rim of amorphous silica that appears to be secondary. Fine-grained light material speckled through both types of layers is mainly authigenic calcite (see Plate 18, Figure 1).

Figure 3 Sample 49.1-2-core catcher (cross-polarized light, $\times 29)$ :

Chert of probable Late Jurassic (Tithonian) age. Poorly preserved radiolarian molds in matrix of very even-grained microcrystalline quartz. Some molds filled by fibrous chalcedonic quartz (light), others are hollow or partly filled by opaline silica (dark).

Figure 4 Sample 51.0-2-1 (cross-polarized light, $\times 29$ ):

Banded grayish-red chert of Cretaceous age, containing very poorly preserved planktonic foraminiferal and radiolarian (?) remains. Dark layer toward bottom is calcareous chert in which calcitic foraminifera are embedded in a cryptocrystalline, siliceous matrix which has apparently replaced a chalk ooze; foraminiferal interiors remain largely unfilled or are partly filled by secondary calcite crystals (cf. Plate 18, Figures 3-5, and Plate 19, Figures 3 and 4). In the lighter band at the top, the microfossil interiors are largely filled by fibrous chalcedonic quartz.

Figure 5 Sample 50.0-2-core catcher (cross-polarized light, $\times$ 29):

Upper Jurassic chert consisting of silicified planktonic foraminifera and Radiolaria (?) in matrix of cryptocrystalline quartz. Dark mottle at center is caused by concentration of fine opaque material (iron oxides?) in the matrix. Microfossils largely filled by chalcedonic quartz.

Figure 6 Sample 52-8-1 (plain light, $\times 29$ ):

Slightly friable Upper Cretaceous radiolarian mudstone. Radiolaria and spicules are secondarily infilled by chalcedonic quartz. Matrix appears to be very finegrained mixture of clay minerals, iron oxides and cryptocrystalline silica. 

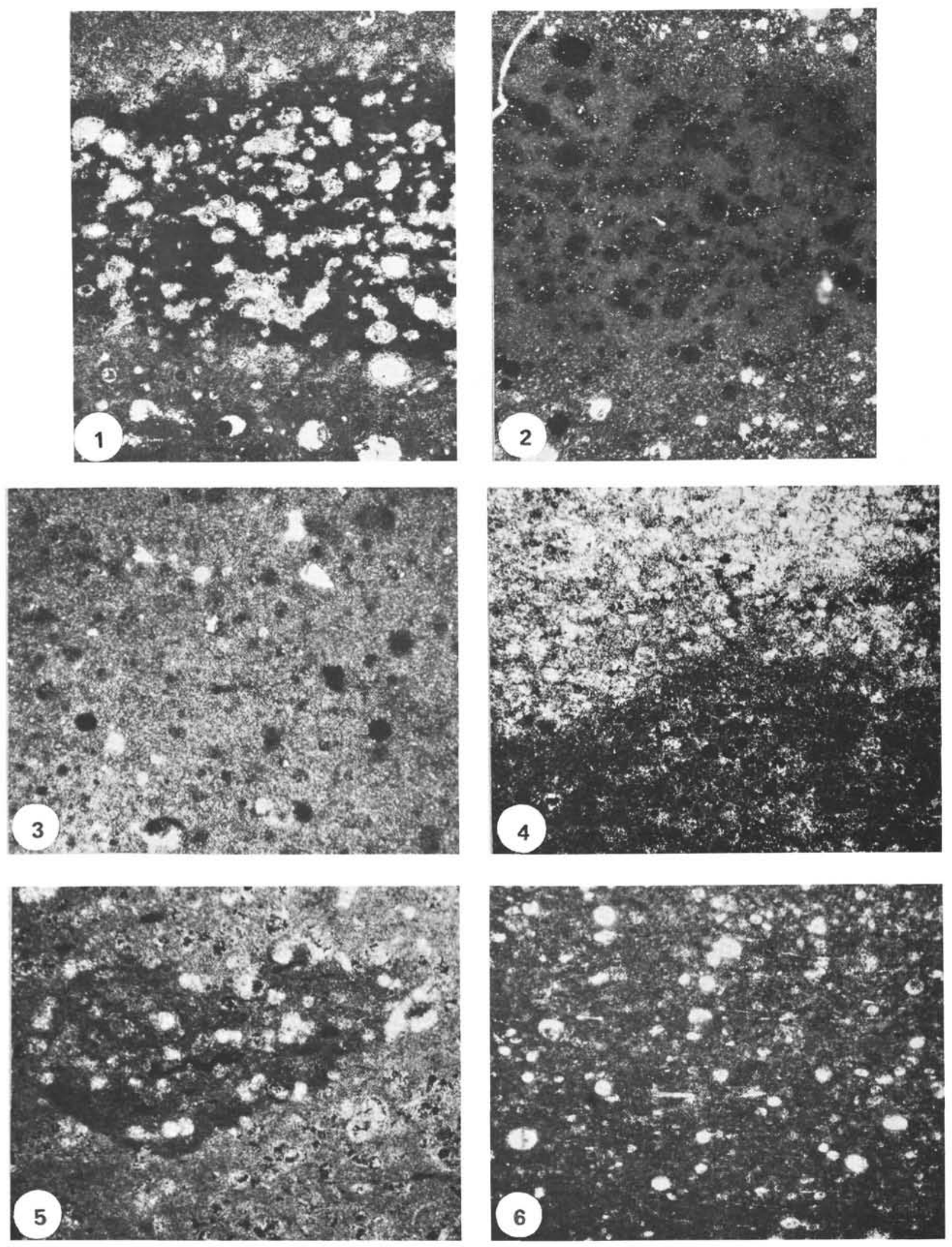


\section{PLATE 14}

Photomicrographs of Cherts, Radiolarian Mudstones and a Calcite Vein in Basalt

Figure 1

Sample 44-5-core catcher (cross-polarized light, $\times 29$ ): Middle Eocene chert showing contact between very even grained chert below (light) and incompletely silicified foraminiferal ooze above. Few indications of microfossils are preserved in the even grained chert. The foraminiferal shell walls in the incompletely silicified part have been replaced by fine, secondary quartz and a spectrum of preservation is evident.

Figure 2 Same sample as above (plain light, $\times 29$ ):

Note poor preservation of silicified foraminifera in the incompletely silicified part (dark).

Figure 3 Sample 45.1-2-core catcher (plain light, $X 29$ ):

Upper Eocene, slightly friable radiolarian mudstone. Very poorly preserved radiolarian remains in dense matrix of mixed cryptocrystalline silica, clay minerals and iron oxides. Spumellarian toward upper left, nasselarian at lower center. The microfossils are now entirely secondary quartz, mainly fibrous chalcedonic quartz.

Figure $4 \quad$ Sample 45.1-2-core catcher (plain light, $X$ 29):

Same type of rock as in Figure 3, except that most of the radiolarian interiors are partially to completely filled with opaline silica. Note wide variation in microfossil preservation.

Figure 5 Sample 50.0-2-3 (cross-polarized light, $X$ 117):

Upper Jurassic chert. Light areas are poorly preserved radiolarian molds filled by chalcedonic quartz; in matrix of cryptocrystalline quartz containing small dark streaks of fine-grained, reddish-brown iron oxides.

Figure 6 Sample 54.0-8-1 (plain light, $\times 29$ ):

Calcite vein in basalt forming basement rock at Site 54 . To the left and lower right is the variolitic basalt of the wall rock. In center and at upper right is coarsegrained, very irregular mosaic of the vein-filling calcite. The latter appears very cloudy due to numerous included small fragments of volcanic rocks, and finegrained zeolites and iron oxides. Plate 21 , Figure 3 is a photograph of the hand specimen from which the thin-section was taken. 

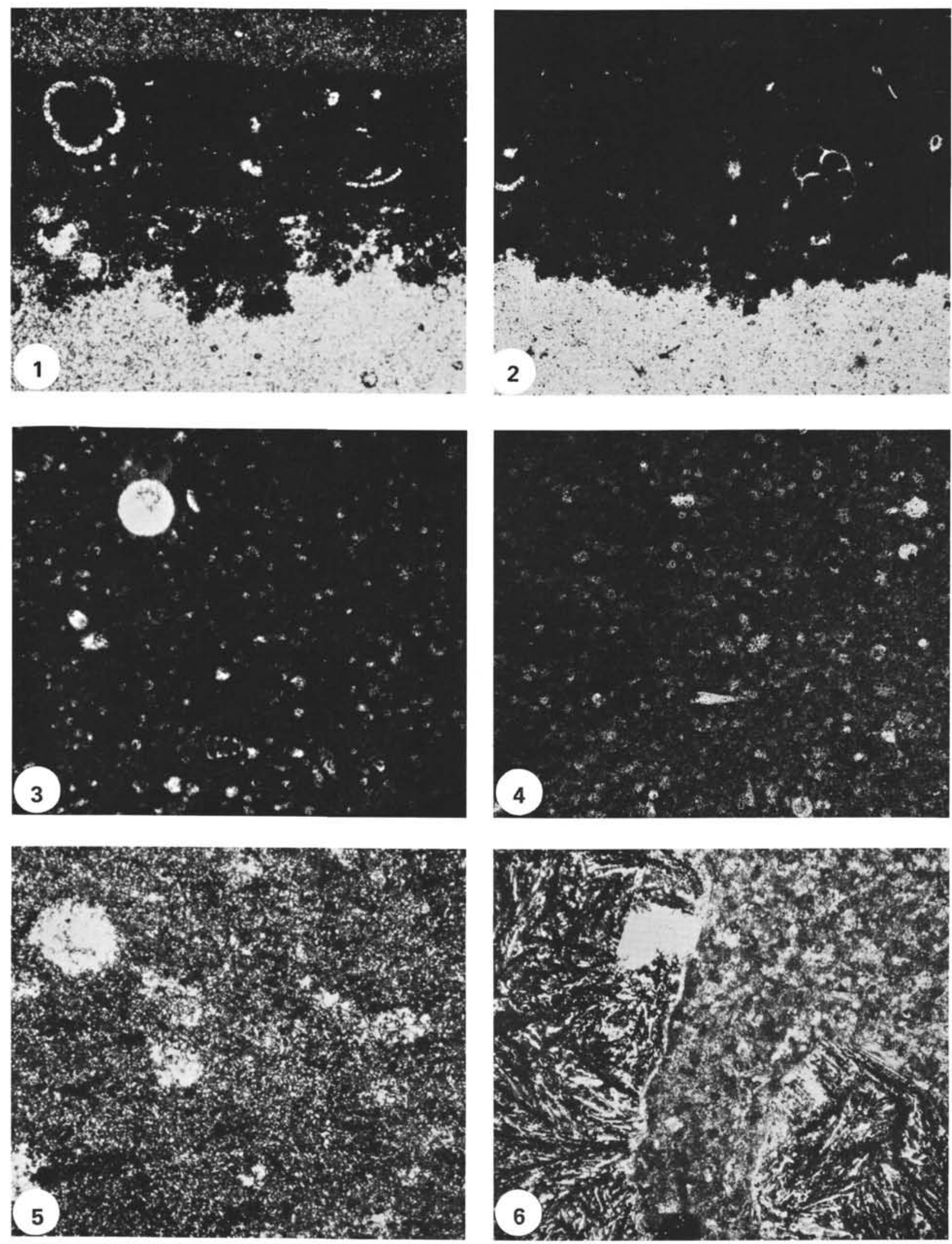


\section{PLATE 15}

Photomicrographs of Microfossil Preservation and Veins in Radiolarian Mudstones and Cherts

Figure 1 Sample 46.0-1-6 (cross-polarized light, $X$ 184):

Sheaves of length fast, fibrous chalcedonic quartz filling radiolarian mold; from radiolarian mudstone.

Figure 2 Sample 45.1-2-core catcher (cross-polarized light, $X 117)$ :

Sheaves of fibrous, length fast, chalcedonic quartz filling radiolarian mold that is also partially infilled by dark, fine-grained matrix material at top; rock is radiolarian mudstone.

Figure 3 Sample 46.0-1-6 (plain light, $\times 117$ ):

Radiolarian remains in Cretaceous radiolarian mudstone. Three distinct radiolarian molds at left center, lower center and lower right have empty interiors and marginal linings of amorphous silica showing spherulitic structure. Less distinct microfossil remains (light speckled patches) are largely infillings of secondary amorphous silica. Matrix (dark) is very fine-grained mixture of cryptocrystalline silica, carbonates, clay minerals and iron oxides.

Figure 4 Sample 45.1-2-core catcher (cross-polarized light, $X 117)$ :

Vein, in upper Eocene radiolarian mudstone, filled partly by length fast chalcedonic quartz (white), partly by irregular patches of the matrix material in the rock (dark). The latter probably are pieces of the wall rock that sloughed off into an open crack while chalcedonic quartz was being precipitated in it.

Figure 5 Sample 50.0-2-core catcher (cross-polarized light, $\times 29$ ):

Vein of length fast fibrous chalcedonic quartz in Upper Jurassic chert.

Figure 6 Sample 44.0-5-core catcher (plain light, $X$ 29):

Geopetal structure within planktonic forminiferal test in incompletely silicified, Middle Eocene foraminiferal ooze (cf. Plate 14, Figures 1 and 2). Shell wall is replaced by secondary quartz, the "ceiling" is an infilling of clear, fibrous chalcedonic quartz that is length fast, and the "floor" is composed of fine-grained matrix material. 

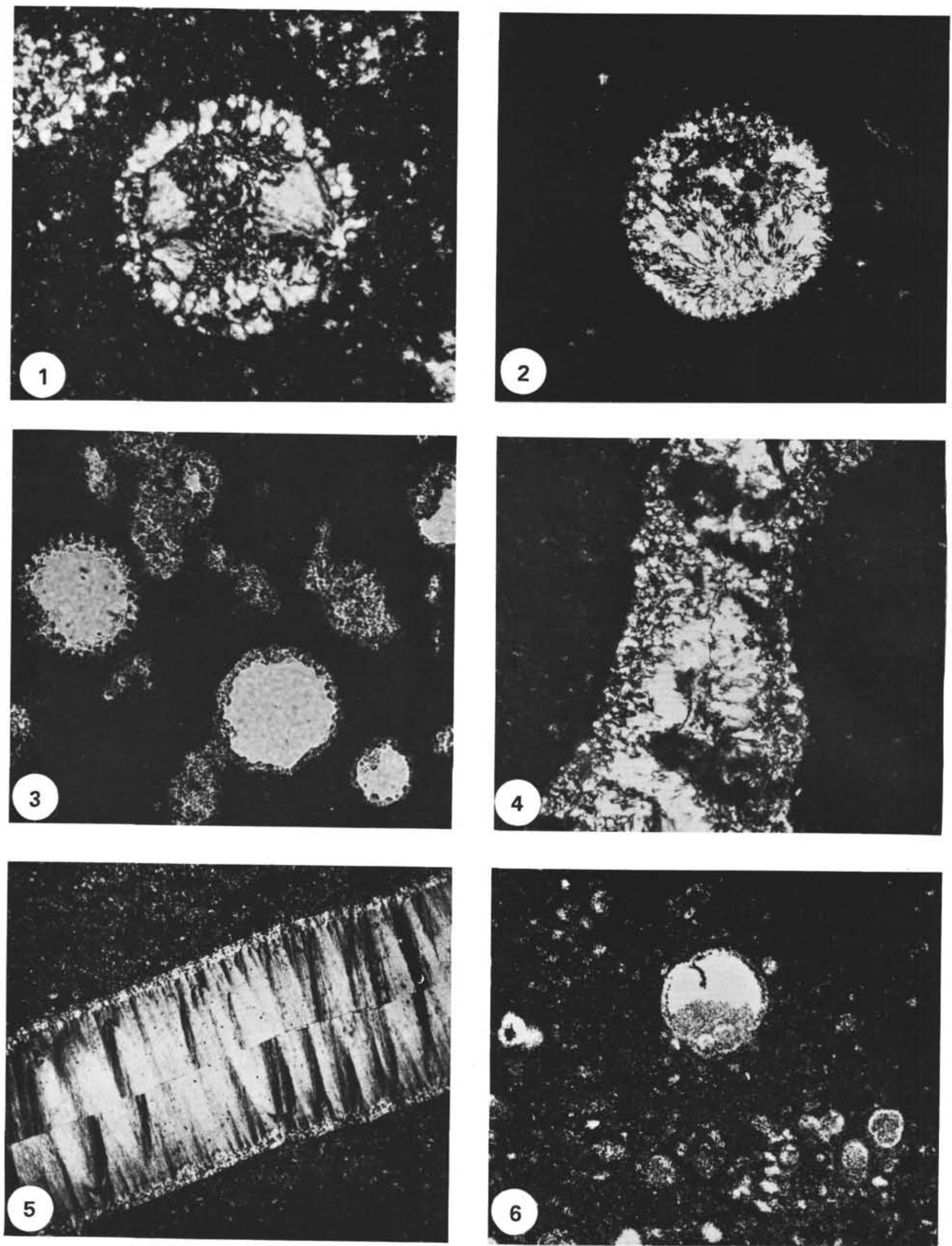
PLATE 16

Transmission Electron Micrographs of Cherts and Radiolarian Mudstones

Figure 1 Sample 45.1-2-core catcher (X 6300):

Upper Eocene radiolarian mudstone. At right center and upper center are sheaves of fibrous chalcedonic quartz probably filling interiors of microfossils (cf. Plate 15, Figure 2).

Figure 2 Sample 52.0-8-3 (× 3820):

Sheaves of fibrous chalcedonic quartz in cherty layer within Cretaceous radiolarian mudstone. Note sheaves of crystals radiating from several directions.

Figure 3 Same sample as Figure 2, cherty layer (X 3820): Fibrous chalcedonic quartz crystals elongated roughly horizontally in photograph. Note variation in crystal size and shape.

Figure 4 Same sample as Figure 2, but from a layer of radiolarian mudstone ( $\times 3820)$ :

Somewhat platy siliceous material, possibly cristobalite. Note irregularity of grain shape and poor definition of grain boundaries. Tiny pits are probably fluid-filled inclusions.

Figure 5 Same sample as Figure 2, radiolarian mudstone (X 6300):

Higher magnification view of platy material (cristobalite?) with poorly defined grain boundaries and numerous liquid inclusions.

Figure 6 Same sample as Figure 2 cherty layer (X 3820): Fibrous chalcedonic quartz encircling and radiating out from circular body, at lower left, that is probably an iron-oxide granule. 

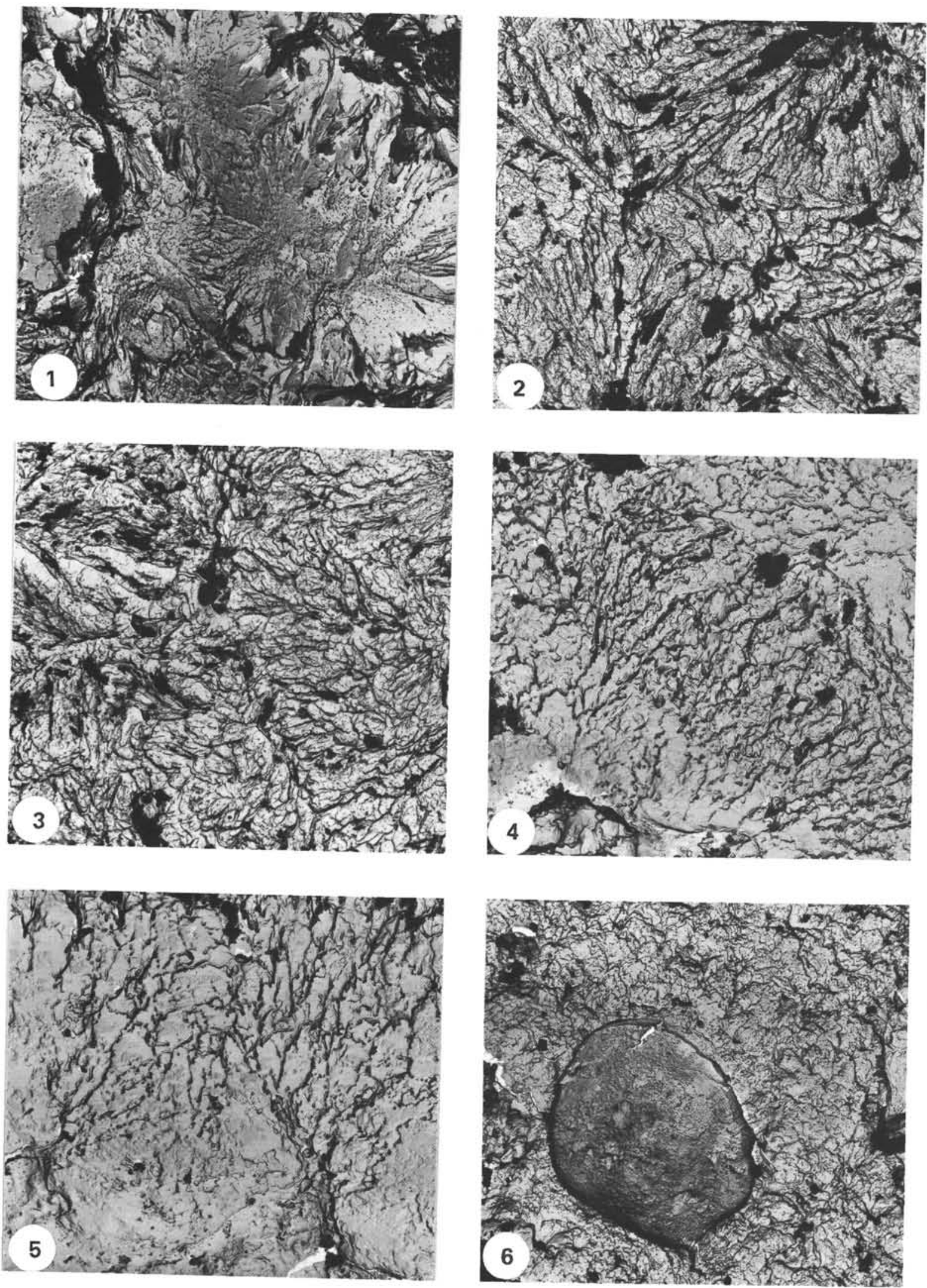
PLATE 17

Transmission Electron Micrographs of Cherts and Radiolarian Mudstones

Figure $1 \quad$ Sample 45.1-2-core catcher (X 8315):

High magnification view of platy material (cristobalite?) in radiolarian mudstone of late Eocene age. Grain boundaries are poorly defined but sheaves of platy material appear to be arranged in layers.

Figure 2

Sample 52.0-8-3 (X 11,340):

High magnification view of chalcedonic quartz crystals in cherty layer within radiolarian mudstone of Cretaceous age. Note elongate shape of crystals and abundance of tiny pits, probably fluid inclusions.

Figure 3 Sample 50.0-2-core catcher $(\times 11,340)$ :

High magnification view of cryptocrystalline quartz in Upper Jurassic chert. Note abundance of inclusions and tendency toward more equigranular shape of crystals compared with the varieties of siliceous materials illustrated in Plate 16 and in Figures 1 and 2 above.

Figure 4 Same sample as in Figure $3(\times 11,340)$ :

Note irregular grain boundaries and abundance of inclusions.

Figure 5 Sample 44-5-core catcher (X 15,720):

High magnification view of a few grains of cryptocrystalline quartz in a Middle Eocene silicified chalk ooze. Note irregular and sometimes indefinite grain boundaries and abundance of inculsions.

Figure 6 Same sample as in Figure $5(\times 23,130)$ :

High magnification view showing density and distribution of pits, probably originally inclusions, in a few grains of cryptocrystalline quartz. 

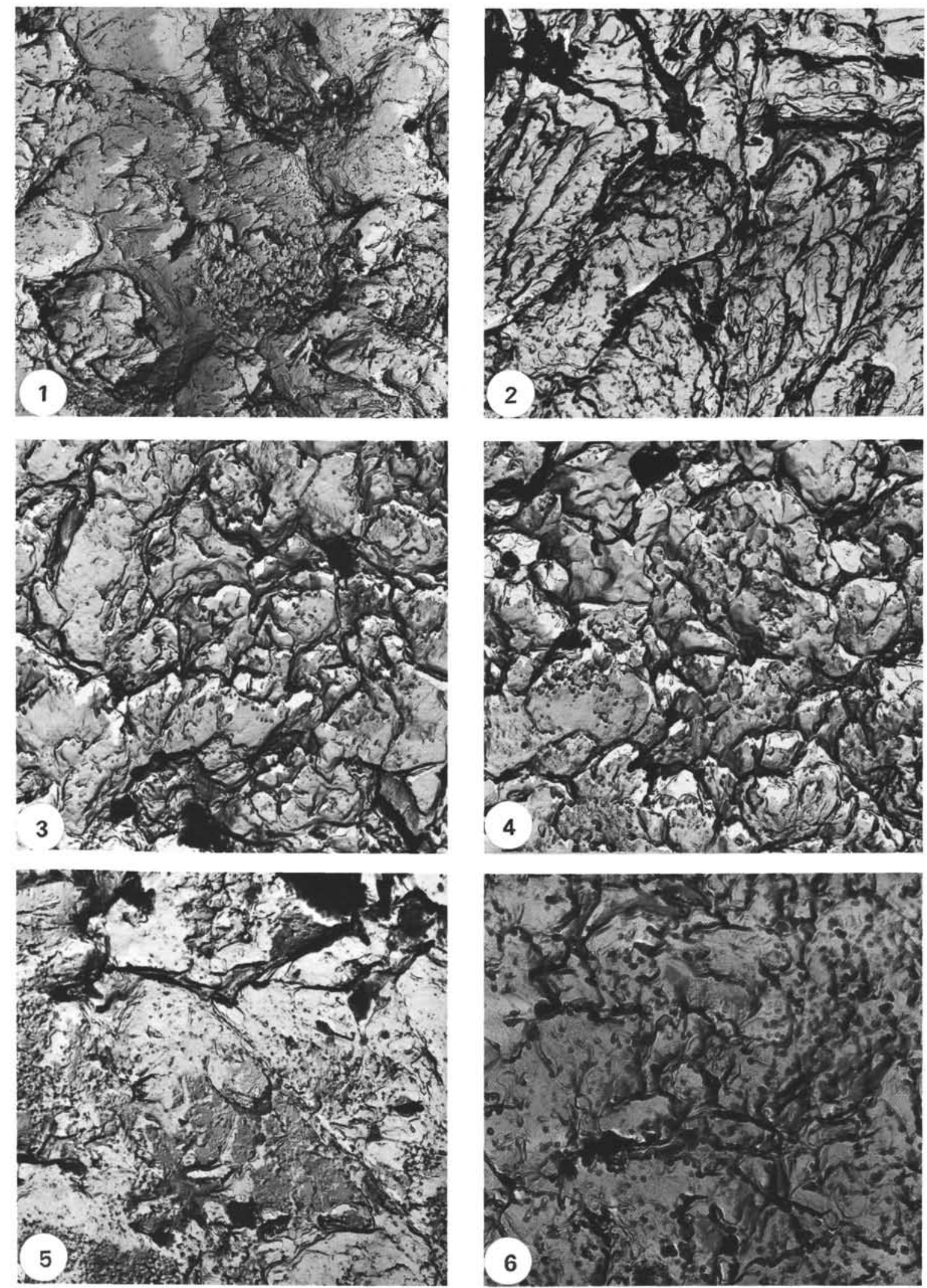


\section{PLATE 18}

Transmission Electron Micrographs of Cherts and Radiolarian Mudstones

Figure 1

Figure 3

Figure 4

Figure 5

Figure 6
Sample 45.1-2-core catcher (X 6300):

Crystal of unidentified rhombic mineral, probably authigenic calcite, in cryptocrystalline matrix of radiolarian mudstone of late Eocene age.

Sample 44-5-core catcher ( $\times 11,340)$ :

Very small euhedral to subhedral calcite crystals in Middle Eocene silicified chalk ooze.

Sample 51.0-2-1 (× 3820):

Interior of planktonic foraminiferal chamber in an incompletely silicified, Cretaceous chalk ooze. Large crystal in center is a carbonate mineral, probably calcite or dolomite; surrounding this is roughly equigranular mosaic of secondary anhedral to subhedral calcite crystals that partially infill the foraminiferal chamber. See also Plate 13, Figure 4, and Plate 19, Figures 3 and 4.

Same sample as in Figure 3 (X 5010):

Detail of contact between silicified foraminiferal shell wall (top) and cavity-filling secondary calcite crystals (bottom).

Same sample as in Figure 3 (X 6300):

High magnification view of subhedral, cavity-filling calcite crystals.

Sample 52.0-8-3 (X 6300):

Unidentified silt-size detrital mineral in cryptocrystalline silica matrix of radiolarian mudstone. 

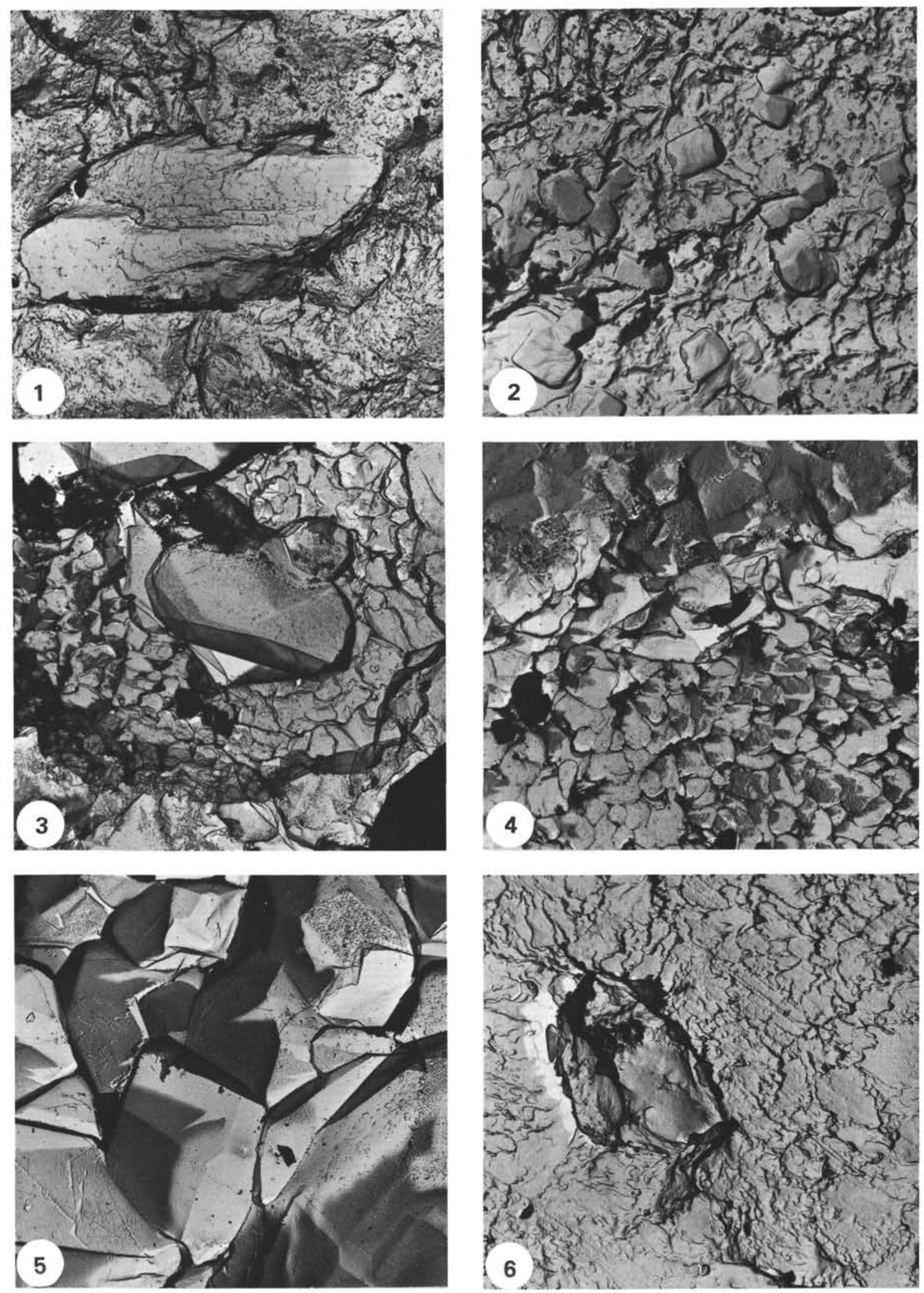
PLATE 19

Scanning Electron Micrographs of Zeolites and Cherts

Figure $1 \quad$ Sample 47.2-6-core catcher $(\times 450)$ :

Twinned phillipsite crystal plastered with coccoliths. Crystal was separated from a reddish-brown, heavily burrowed nannoplankton chalk ooze that occurs along an unconformable surface separating Upper Miocene and lower Eocene chalk oozes at Site 47.

Figure 2 Same sample as in Figure $1(\times 250)$ :

Twinned phillipsite crystal, partly coated with coccoliths and clay minerals.

Figure 3 Sample 51.0-2-1, polished and etched surface (X 840): This chert is an incompletely silicified foraminiferal chalk ooze (cf. Plate 13, Figure 4). At center and toward top left secondary clacite crystals line interiors of two chambers of a planktonic foraminifera which is embedded in a cryptocrystalline quartz matrix (high standing areas surrounding foraminiferal chambers). See also Plate 18, Figures 3 - 5.

Figure 4 Same sample as in Figure 3, polished and etched surface (X 1000):

Vug surrounded by cryptocrystalline quartz (high standing areas) and partly infilled by subhedral to euhedral calcite crystals. 

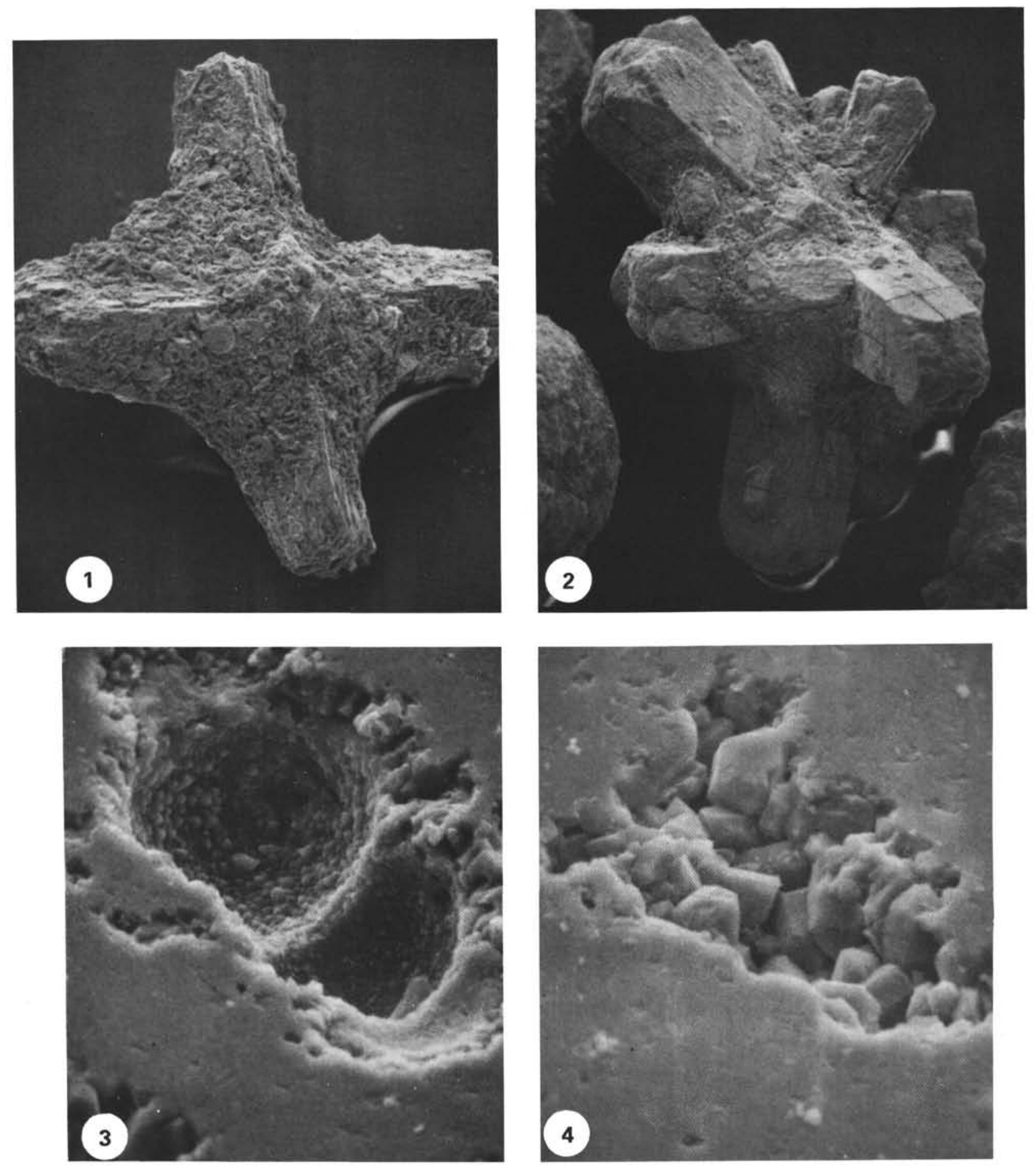
PLATE 20

Tertiary Limestone Breccias Recovered at Site 53

(Sample 53.0-6-2; all photographs natural size.)

Figure 1 Surface slabbed perpendicular to core axis. Angular clasts of reddish-brown and yellowish-brown limestone (darker in photograph) are in places rimmed by sparry calcite (white). Clasts are embedded in matrix of light reddish-brown limestone, indicated by letters "a" in the photograph. Two open vugs (dark) are to the right and below the letter " $b$ ".

Figure 2 Surface slabbed perpendicular to core axis. Clasts of reddish-brown limestone (darker) in matrix of light reddish-brown limestone (lighter). Small black specks in photograph are small vugs.

Figure 3 Surface slabbed parallel to core axis. Reddish-brown limestone in irregular patches (e.g. at "a") is surrounded by light reddish-brown limestone (e.g. at "b"). Small dark specks are tiny vugs.

Figure 4 Surface slabbed perpendicular to axis of core:

Clasts of reddish brown limestone ("a"), in part rimmed by white sparry calcite and cemented in matrix of light reddish-brown limestone ("b"); note suggestion of flow banding in latter and also in similar material of Figure 1. 

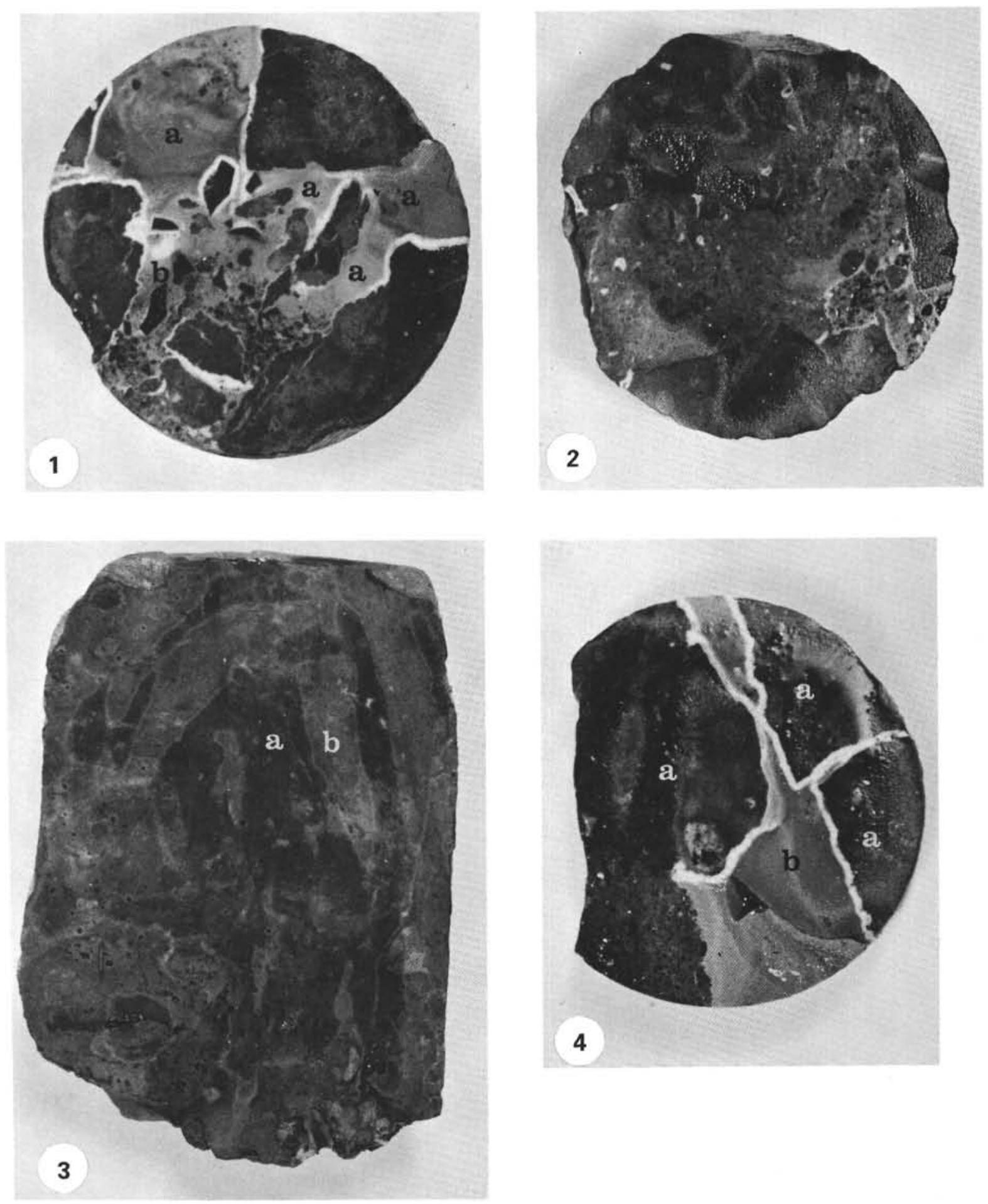


\section{PLATE 21}

Basement Rocks at Site 54 (All photographs natural size, surfaces slabbed perpendicular to core axis.)

Figure 1

Sample 54.0-8-1:

Volcanic breccia.

Clasts of black volcanic glass (Sideromelane) with yellowish alteration rims of palagonite, in lightcolored, clay- and glass-rich tuffaceous material.

Figure 2 Sample 54.0-8-1:

Contact between volcanic breccia and underlying basalt with numerous veins. Along contact to the left is a partial rim of dark basaltic glass (below and to the left of letter " $x$ ") that is not present toward the right. Note open vugs lying above letters "a". Veins are filled by calcite and zeolites (harmotome).

Figure 3 Sample 54.0-8-1:

Basalt with calcitic veins. The veins also contain some volcanic rock fragments and fine-grained tuffaceous material. Thin-section view of a vein is shown in Plate 14. Figure 6; the field of view in Plate 14, Figure 6, is located just to the left of the letter "a". 


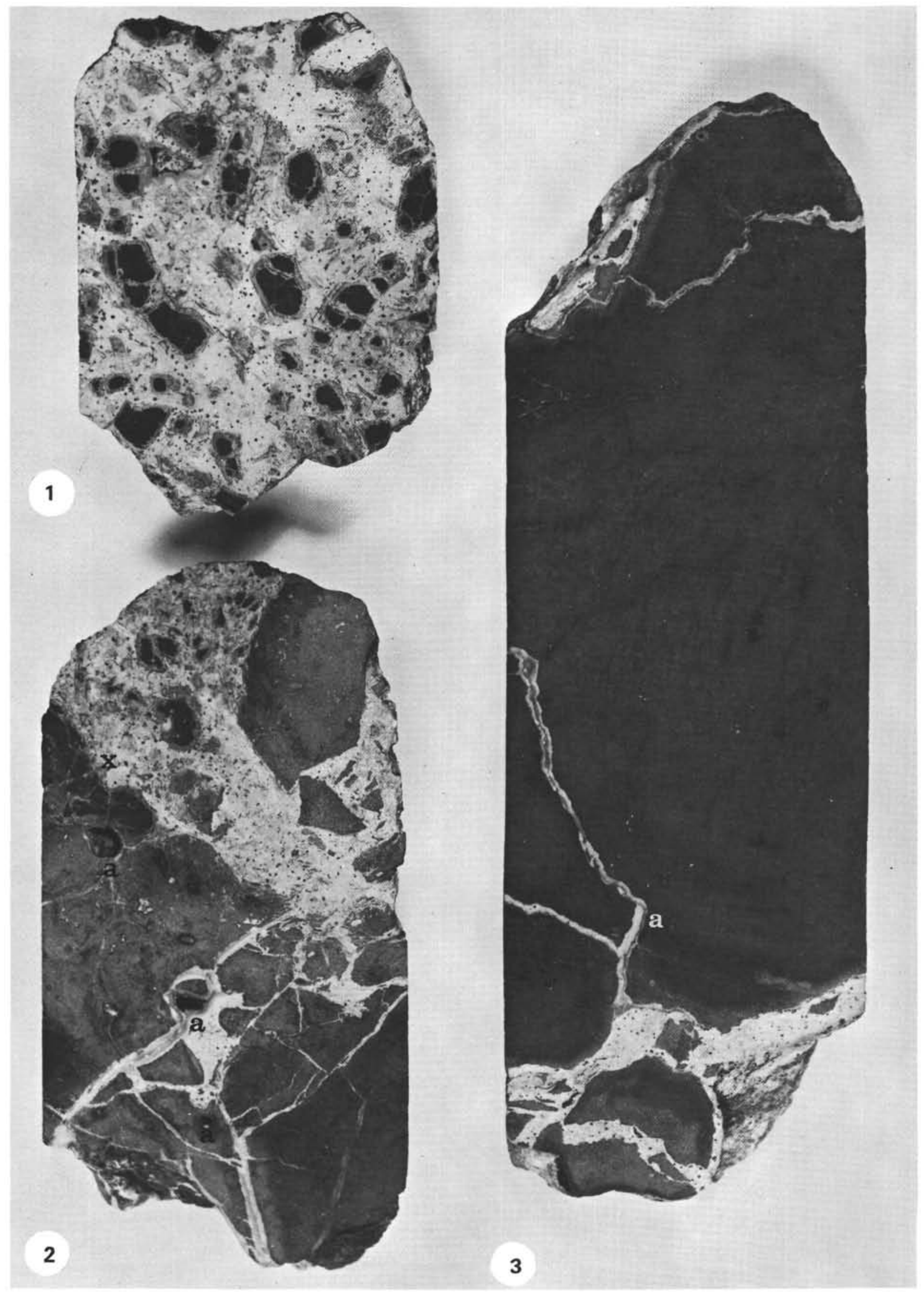




\section{PLATE 22}

Sediment-Basement Contact at Site 57 (Natural size)

Somewhat consolidated white nannoplankton-foraminiferal chalk ooze of late Oligocene lies above porphyritic olivine dolerite (see Plate 23, Figure 3, for thin-section view of this contact). Convexity of contact surface and slight distortion of laminae in chalk ooze may be the result of drilling disturbance. 


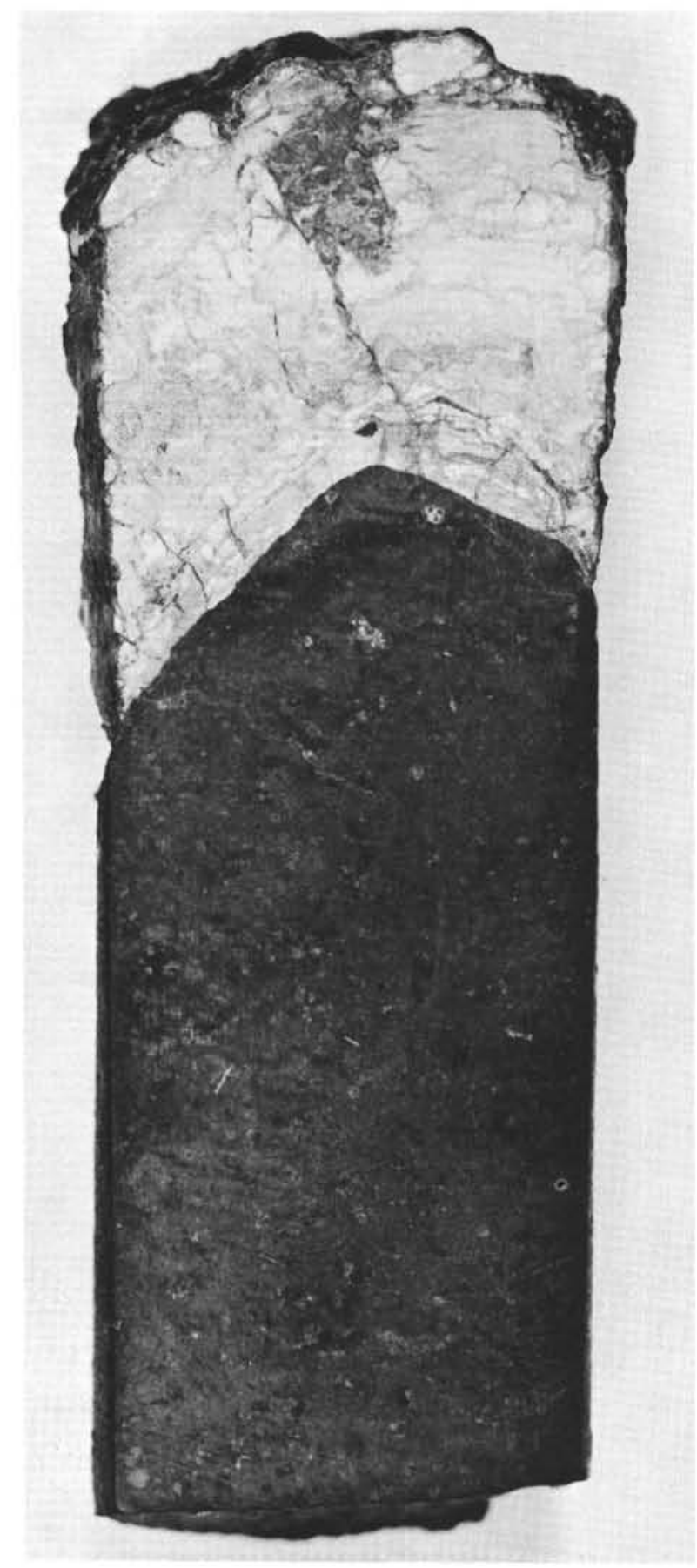


PLATE 23

Photomicrographs of Limestones

Figures 1\&2 Sample 45.1-3-core catcher (both $\times 29$; Figure 1-plain light, Figure 2 -cross-polarized light):

Cretaceous (Cenomanian) limestone with microfossils showing varying stages of preservation and alteration. The large vug in the center probably represents a mold resulting from dissolution of a planktonic foraminifera; the vug has a thin rim of secondary calcite. Radiolarian molds below letters "a" are filled by secondary, cryptocrystalline quartz. Above " $\mathrm{b}$ " is an indeterminant microfossil partly infilled by micrite, partly by secondary calcite. Micritic matrix is lithified coccolith-rich ooze (see also Plate 27, Figures 2-4, and Plate 28, Figures 1-3).

Figure 3 Sample 57.1-4-6 (plain light, $\times$ 29):

Contact between upper Oligocene nannoplanktonforaminiferal chalk ooze above and olivine dolerite below (see Plate 22). Chalk ooze is firm and somewhat consolidated; note plagioclase grain (white) in chalk ooze just to the right of center. Also note that some foraminiferal chambers are partly to completely filled by ooze, while others remain as voids.

Figure 4 Same sample as in Figure 3 (cross-polarized light, X 29):

Interiors of most foraminiferal chambers have remained as voids. Dark grain above " $a$ " is fragment of altered, fine-grained basalt.

Figure $5 \quad$ Sample 53.0-8-1 (plain light, $\times 29$ ):

Tertiary limestone breccia. Fragments of altered limestone in sparry calcite cement.

Figure 6 Same sample as in Figure 5 (plain light, $\times 29$ ):

Limestone breccia cemented by sparry calcite. Note indications of poorly preserved microfossils (Radiolaria or foraminifera?), now mainly molds filled by sparry calcite. 

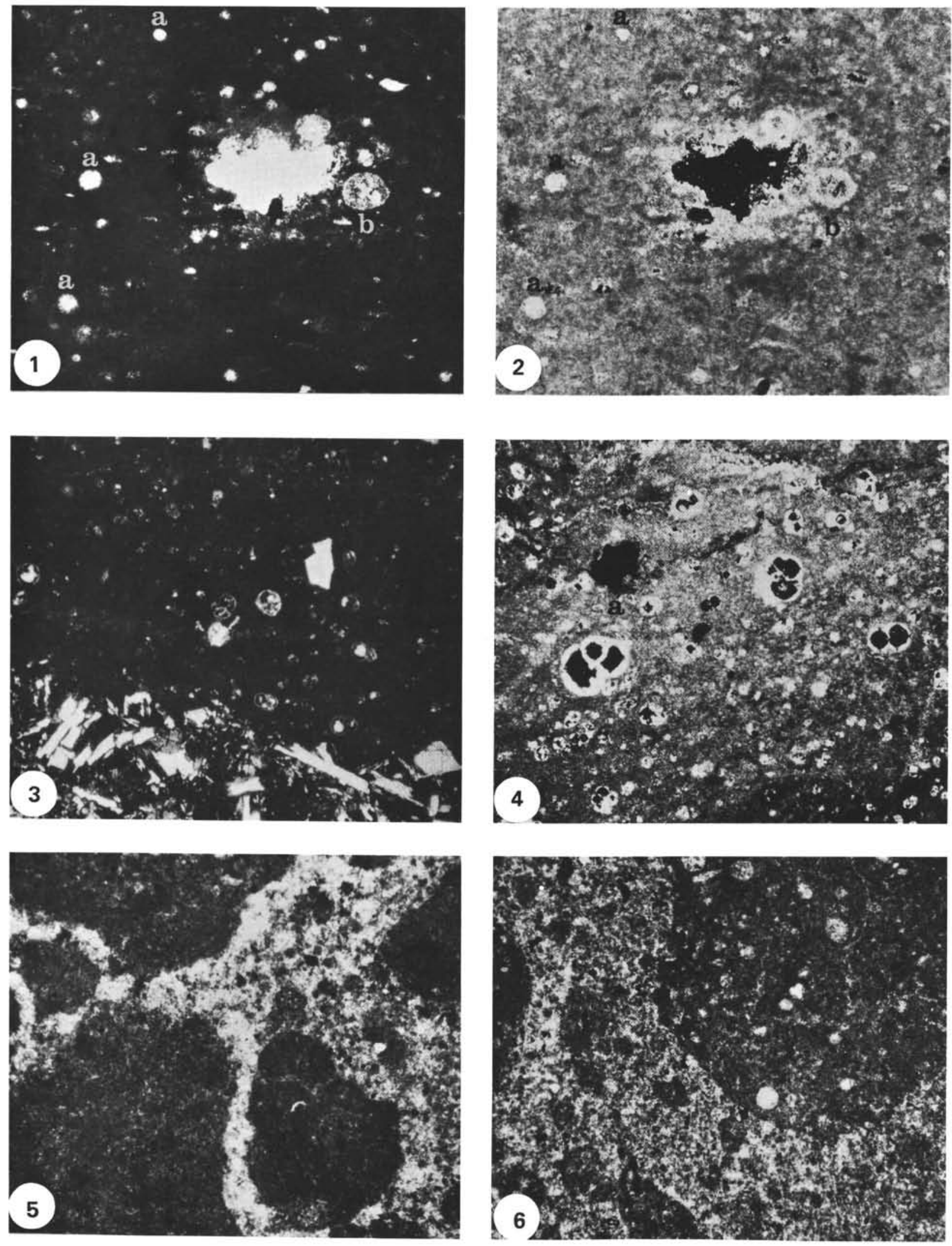


\section{PLATE 24}

Photomicrographs of Tertiary Limestones Recovered at Site 53

Figure 1 Sample 53.0-8-core catcher (plain light, $\times 117$ ):

Euhedral zeolite (harmotome) crystals within a calcite vein that cuts limestone. Dark material toward top is fine-grained limestone that fills the center of the vein (see Figure 6 below).

Figure 2

Sample 53.0-5-core catcher (plain light, $\times 29$ ):

Altered limestone.

Mold of microfossil at center is filled with secondary sparry calcite. Note numerous small dark specks of iron oxides in fine-grained matrix.

Figure 3 Sample 53.0-8-core catcher (cross-polarized light, $\times 117)$ :

Ghostlike remnants of microfossils in recrystallized matrix. Numerous dark grains are granules of reddishbrown iron oxides. Sparry calcite cement at upper right.

Figure 4 Same sample as in Figure 3 (cross-polarized light, X 29):

Sparry calcite vein that cuts through a limestone breccia from upper left to lower right. Note inclusionrich calcite (dark areas) at margins of vein, growth lines in clearer parts, and void space in center (black).

Figure 5 Sample 53.0-8-1 (plain light, $\times 29$ ):

Composite calcite vein cutting a breccia composed of fragments of limestone and basalt at top, bottom and right. The vein consists of three distinct layers: (1) a thin rim of clear sparry calcite at margins, (2) a thicker layer of cloudy, inclusion-rich calcite (dark areas), and (3) clear calcite, with minor inclusions, in the central part of the vein.

Figure 6 Same sample as in Figure 5 (plain light, $\times 117$ ):

Composite vein in limestone forming the walls of the vein. Faintly laminated material lining vein walls is amorphous silica. The clear (white) crystals are zeolites (harmotome), and the dark material in the center of the vein is fine-grained limestone that must have internally resedimented during the last phase of VeinFilling. 

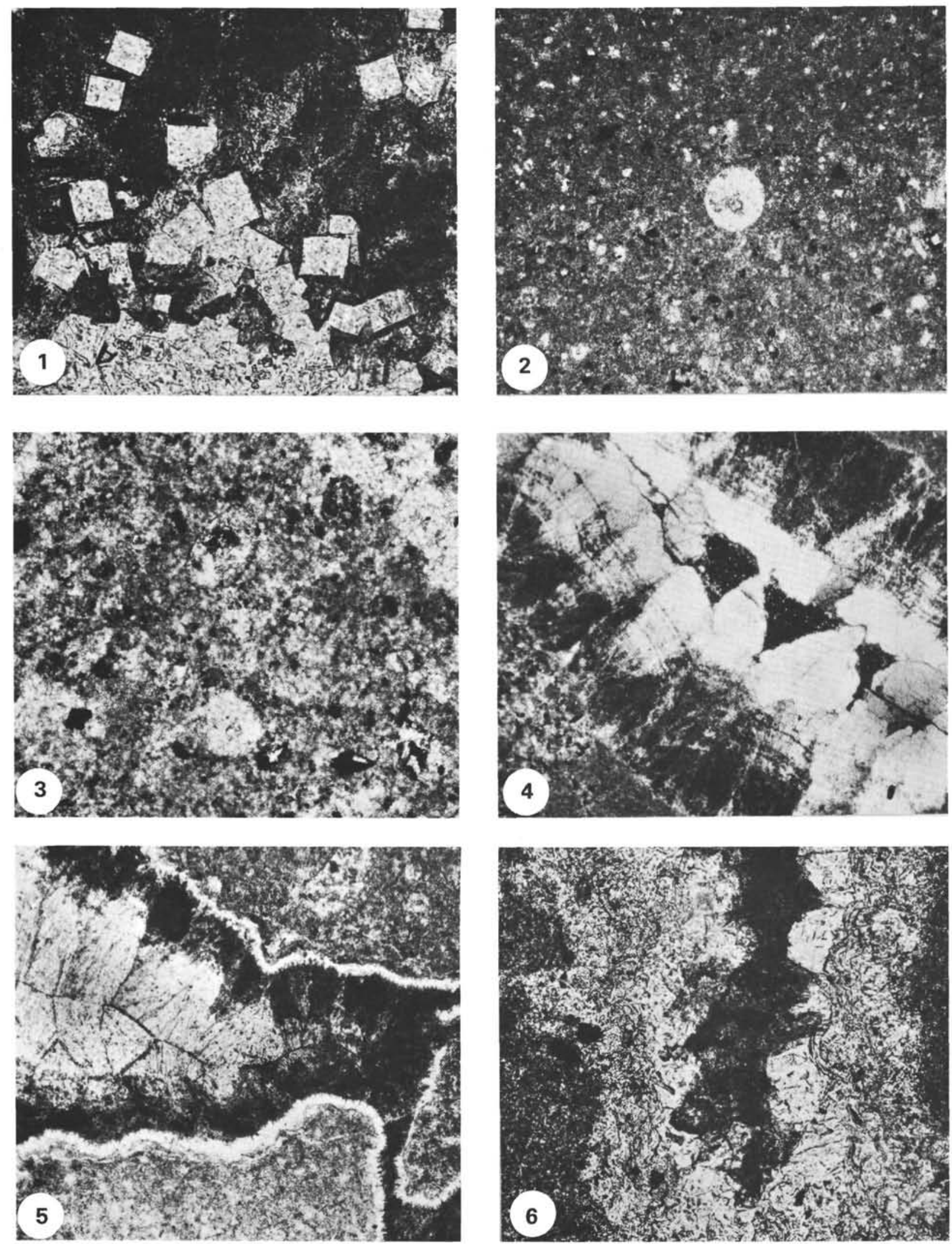


\section{PLATE 25}

Transmission Electron Micrographs of Recrystallized Tertiary Limestones and Calcareous Oozes Recovered at Site 53

Figure 1 Sample 53.0-5-core catcher $(\times 11,340)$ :

Coccolith from recrystallized nannoplankton chalk ooze (cf. Plate 11, Figure 5). Note secondary calcite crystals filling center of coccolith and possible growth of small calcite crystals on plates at right side of coccolith.

Figure 2 Same sample as in Figure $1(\times 6300)$ :

Altered coccolith (Cyclococcolithus neogammation) in which plate boundaries are beginning to disappear due to recrystallization (?).

Figure 3 Same sample as in Figure $1(\times 6300)$ :

Altered discoaster (Discoaster deflandri) showing rounded plate edges, loss of definition between plate boundaries, and possibly growth of small secondary crystals on plate surfaces.

Figure 4 Same sampel as in Figure 1 ( 6300$)$ :

Anhedral calcite grains of probable secondary origin.

Figure 5 Sample 53.0-8-core catcher $(\times 3820)$ :

Poorly preserved coccolith remains cemented in anhedral calcite mosaic of probable secondary origin.

Figure 6 Same sample as in Figure $5(\times 6300)$ :

Coccoliths in mosaic of anhedral calcite grains. Note loss of definition between plate boundaries of individual coccoliths. 


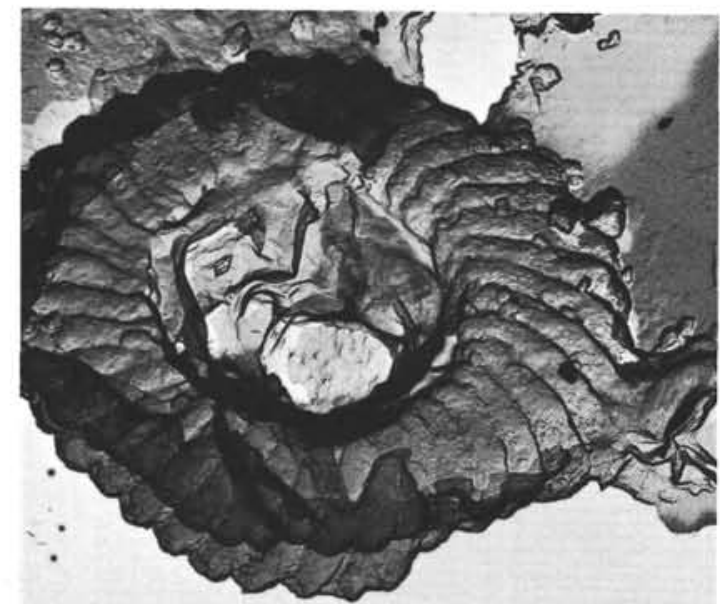

1
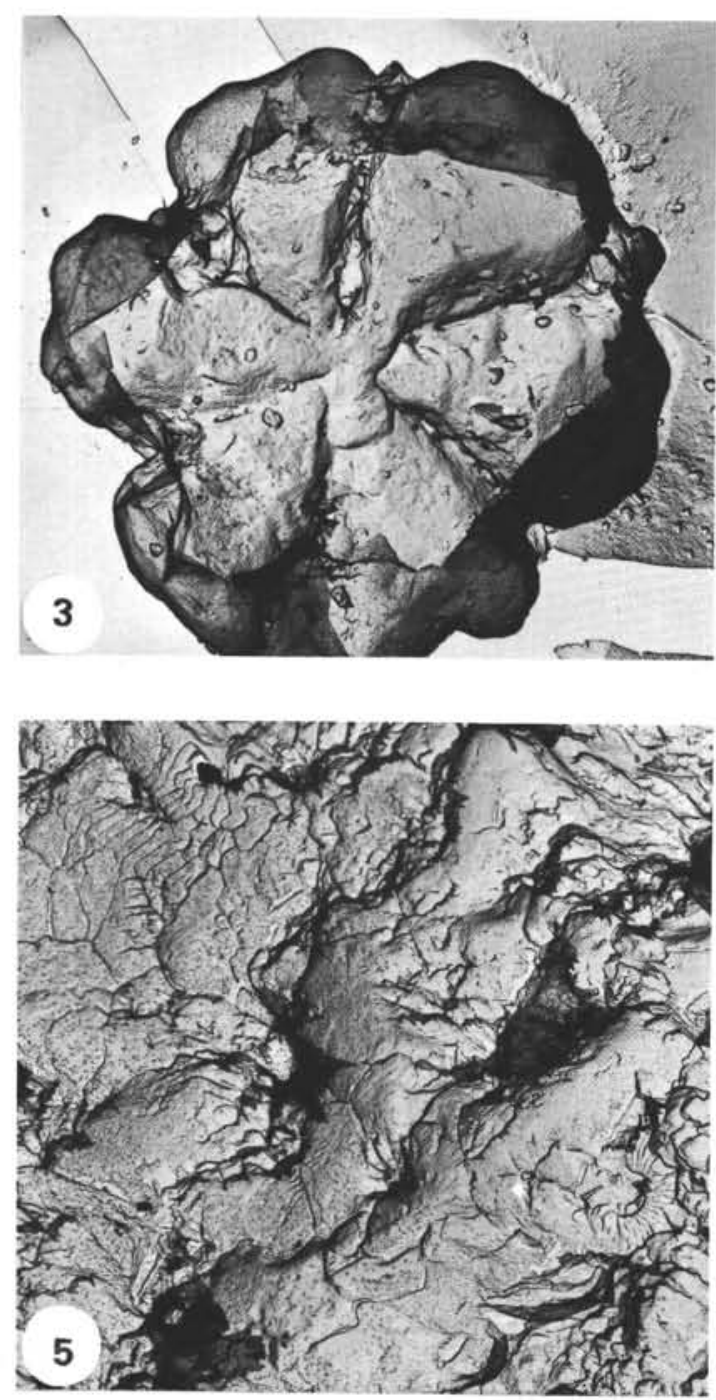
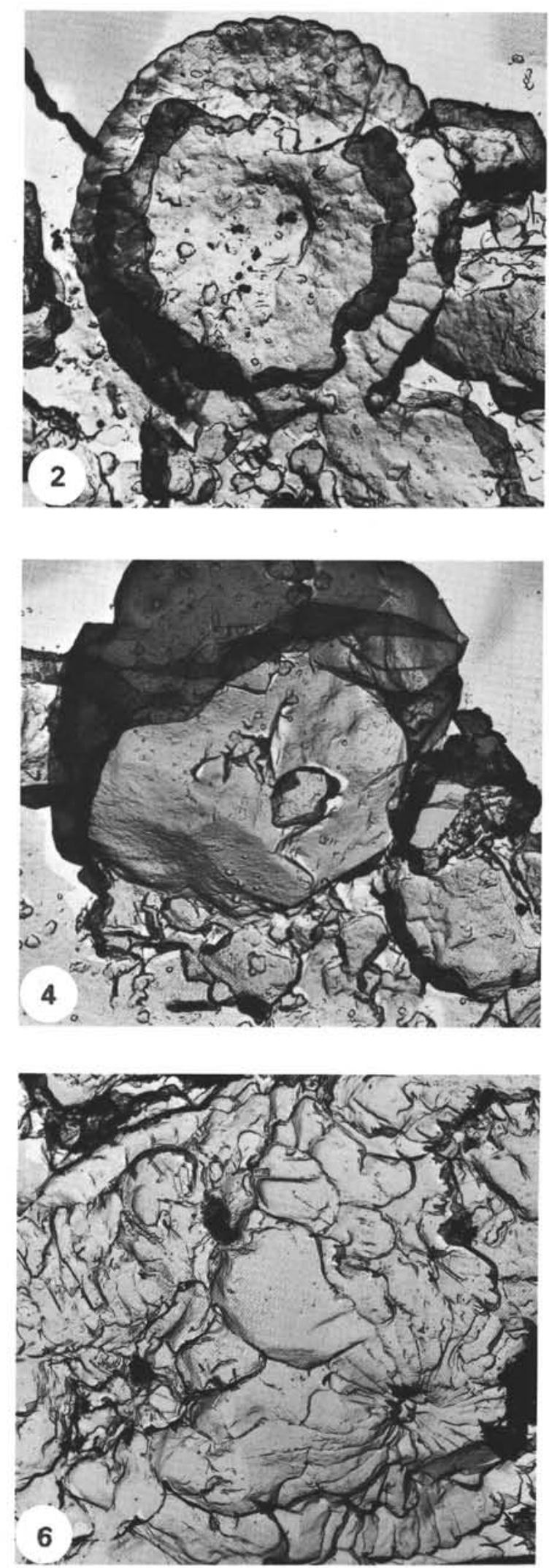
PLATE 26

Transmission Electron Micrographs of Recrystallized Tertiary Limestones Recovered at Site 53

Figure 1 Sample 53.0-8 core catcher $(\times 6300)$ :

Coccolith on right is embayed and partly replaced by surrounding anhedral calcite crystals. At left is relatively coarse microsparry calcite.

Figure 2 Same sample as in Figure $3(\times 8300)$ :

Remains of coccoliths in mosaic of anhedral to subhedral calcite of probable secondary origin. Note relatively straight grain boundaries in the latter.

Figure 3 Same sample as in Figure 1 ( $\times 5010)$ :

Coccolith at top is being replaced around margins by anhedral calcite grains with largely irregular grain boundaries; note loss of definition of plate boundaries within the coccolith, probably the result of recrystallization. Large euhedral crystal at bottom center, probably calcite, appears to transect and replace anhedral calcite mosaic (note included grains).

Figure 4 Same sample as in Figure $1(X 6300)$ :

Anhedral to euhedral carbonate crystals of probable secondary origin. Note faint indications of coccolith plates toward upper right.

Figure 5 Same sample as in Figure $1(\times 8300)$ :

Remnants of coccoliths at top surrounded and partly replaced by anhedral calcite crystals with irregular and curved grain boundaries.

Figure 6 Same samples as in Figure $1(\times 8300)$ :

Mosaic of anhedral calcite grains of probable secondary origin. Note that most grain boundaries tend to be curved and somewhat irregular. 

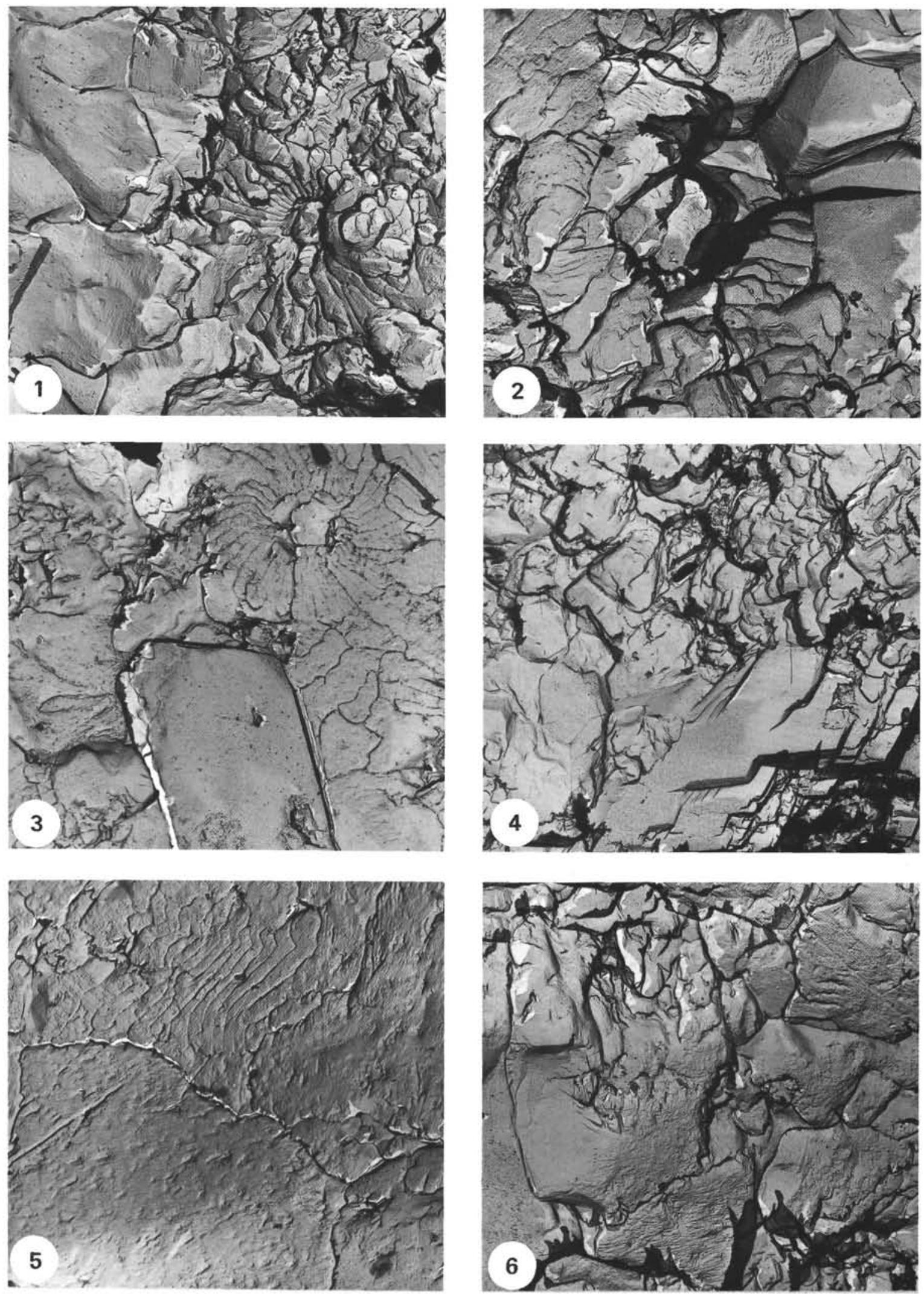


\section{PLATE 27}

Scanning Electron Micrographs of Fracture Surfaces of Limestones Recovered at Sites 45 and 53

Figure 1 Sample 53.0-5-core catcher (X 6000):

Partially recrystallized Tertiary limestone. Partly replaced coccolith in center is surrounded by subhedral carbonate crystals of probable secondary origin.

Figure 2 Sample 45.1-3-core catcher $(\times 10,000)$ :

Well-preserved coccolith in a Cretaceous (Cenomanian) limestone. Subhedral grains surrounding the coccolith are of probably secondary origin.

Figure 3 Same sample as in Figure $2(X 425)$ :

Sperical to hemispherical clusters of aragonite crystals lining interior of microfossil (radiolarian?) cavity.

Figure 4 Same sample as in Figure 2 (X 6000):

Acicular aragonite crystals of the spherical to hemispherical clusters shown in Figure 3. 

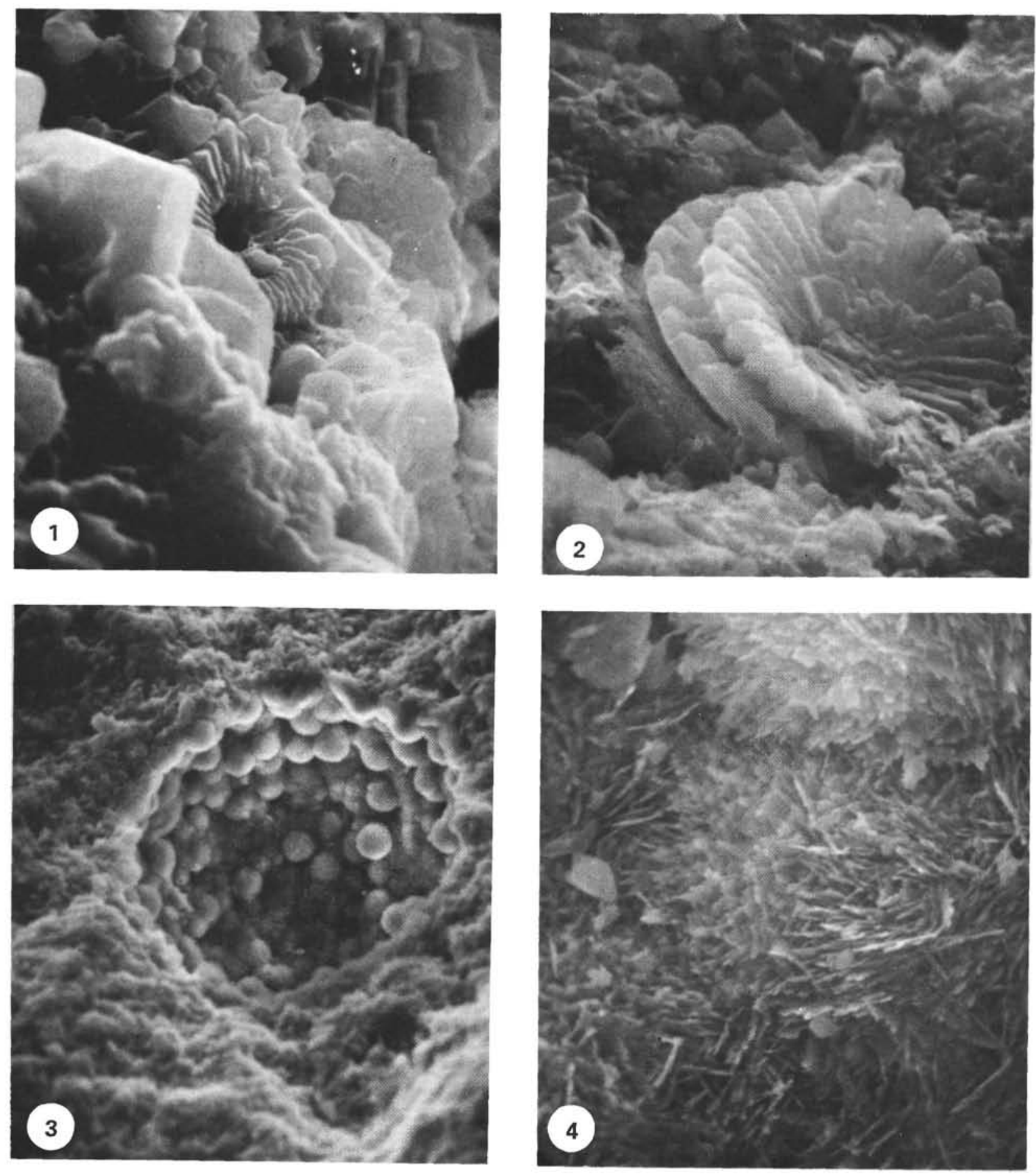
PLATE 28

Scanning Electron Micrographs of Fracture Surfaces of Cretaceous

(Cenomanian) Limestone Recovered at Site 45

(Sample 45.1-3-core catcher)

Figure $1 \times 425:$

Cross section through a foraminiferal test in finegrained, coccolith-rich matrix. Note hemispherical clusters of aragonite crystals on interior of shell. Small square in center outlines the area of micrograph in Figure 2.

Figure $2 \times 2600$ :

Hemispherical clusters of aragonite crystals along interior margin of foraminiferal shell. Note earlier generation of stubby, secondary calcite crystals lining interrior of shell wall. Micrograph Figure 3 is of the lower right corner of this view.

Figure $3 \times 3000$ :

Secondary calcite crystals growing along interior margin of foraminiferal shell wall. These crystals are overgrown in places by clusters of acicular aragonite crystals. 

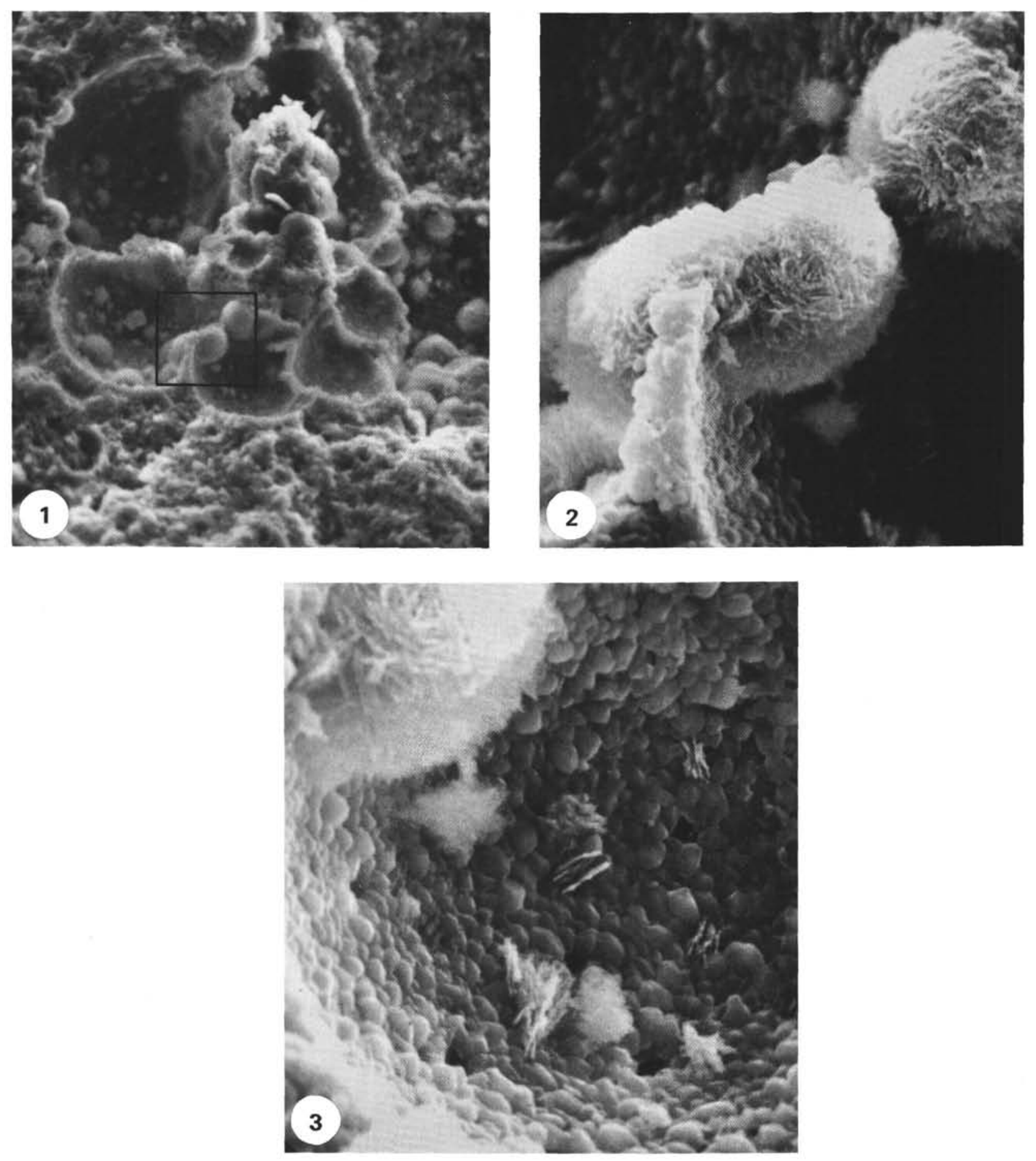
TABLE 5

Siliceous Oozes Recovered During Leg 6

\begin{tabular}{|c|c|c|c|c|c|c|c|}
\hline Hole & $\begin{array}{l}\text { Water Depth } \\
\text { (meters) }\end{array}$ & Core & $\begin{array}{l}\text { Type of } \\
\text { Sediment }\end{array}$ & Age & Color & $\begin{array}{l}\text { Associated } \\
\text { Lithologies }\end{array}$ & Remarks \\
\hline 49.0 & 4282 & 1 & $\begin{array}{l}\text { Diatom- } \\
\text { radiolarian } \\
\text { ooze }\end{array}$ & Pleistocene & Yellowish brown & $\begin{array}{l}\text { Brown zeolitic clay, } \\
\text { marl ooze, clay with } \\
\text { volcanic ash }\end{array}$ & $\begin{array}{l}\text { Ninety centimeter interval of thin } \\
\text { interbedded siliceous ooze, brown } \\
\text { clay and marl ooze. }\end{array}$ \\
\hline 50.1 & 4487 & 1 & $\begin{array}{l}\text { Radiolarian- } \\
\text { diatom ooze }\end{array}$ & Pleistocene & $\begin{array}{l}\text { Yellowish-brown } \\
\text { to brown }\end{array}$ & $\begin{array}{l}\text { Marl ooze volcanic } \\
\text { ash }\end{array}$ & $\begin{array}{l}\text { Layer } 4 \text { meters thick; diatoms } \geqslant \\
\text { Radiolaria; calcareous (nannofos- } \\
\text { sil). }\end{array}$ \\
\hline 51.0 & 5981 & 1 & $\begin{array}{l}\text { Radiolarian- } \\
\text { diatom }\end{array}$ & Miocene & Yellowish brown & Brown zeolitic clay & $\begin{array}{l}\text { Present only as small mottles in } \\
\text { brown zeolitic clay. }\end{array}$ \\
\hline 51.1 & 5981 & 1 & $\begin{array}{l}\text { Radiolairan- } \\
\text { diatom ooze }\end{array}$ & Pleistocene & Light gray-brown & $\begin{array}{l}\text { Volcanic ash brown } \\
\text { clay }\end{array}$ & $\begin{array}{l}\text { Interbedded with volcanic ash in } \\
2.4 \text { meter interval. }\end{array}$ \\
\hline 53.2 & 4629 & 1 & $\begin{array}{l}\text { Radiolarian } \\
\text { ooze }\end{array}$ & Late Miocene & $\begin{array}{l}\text { Brown to gray- } \\
\text { brown }\end{array}$ & $\begin{array}{l}\text { Lies below brown } \\
\text { clay, above volcanic } \\
\text { ash }\end{array}$ & $\begin{array}{l}\text { Interval is } 8 \text { meters thick. Radio- } \\
\text { laria }>\text { sponge spicules }>\text { diatoms. }\end{array}$ \\
\hline 58.1 & 4486 & 1 & Diatom ooze & Pleistocene & Very pale brown & $\begin{array}{l}\text { Chalk ooze } \\
\text { marl ooze }\end{array}$ & $\begin{array}{l}\text { In layer about } 50 \text { centimeters } \\
\text { thick. Composed largely of frus- } \\
\text { tules of Ethmodiscus rex. }\end{array}$ \\
\hline 58.2 & 4486 & 1 & $\begin{array}{l}\text { Radiolarian- } \\
\text { spicule ooze }\end{array}$ & Late Oligocene & Pale brown & $\begin{array}{l}\text { Resedimented gravel } \\
\text { marl ooze }\end{array}$ & $\begin{array}{l}\text { In layers up to one meter thick, } \\
\text { very calcareous (nannofossils). }\end{array}$ \\
\hline 59.1 & 5554 & 3 & Diatom ooze & $\begin{array}{l}\text { Quaternary } \\
\text { (?) }\end{array}$ & $\begin{array}{l}\text { Very pale brown } \\
\text { to yellowish } \\
\text { brown }\end{array}$ & Brown zeolitic clay & $\begin{array}{l}\text { In } 3 \text { layers, } 10 \text { to } 30 \text { centimeters } \\
\text { thick, interbedded with zeolitic } \\
\text { clay. Largely Ethmodiscus rex. }\end{array}$ \\
\hline 59.2 & 5547 & 1.4 & $\begin{array}{l}\text { Radiolarian- } \\
\text { spicule ooze }\end{array}$ & $\begin{array}{l}\text { Late Oligocene } \\
\text { to early } \\
\text { Miocene }\end{array}$ & $\begin{array}{l}\text { Dark brown to } \\
\text { dark yellowish- } \\
\text { brown }\end{array}$ & Brown zeolitic clay & $\begin{array}{l}\text { About } 10.5 \text { meters of radiolarian } \\
\text { ooze recovered in } 4 \text { cores; radio- } \\
\text { larians usually }>\text { sponge spicules } \\
>\text { diatoms. }\end{array}$ \\
\hline
\end{tabular}




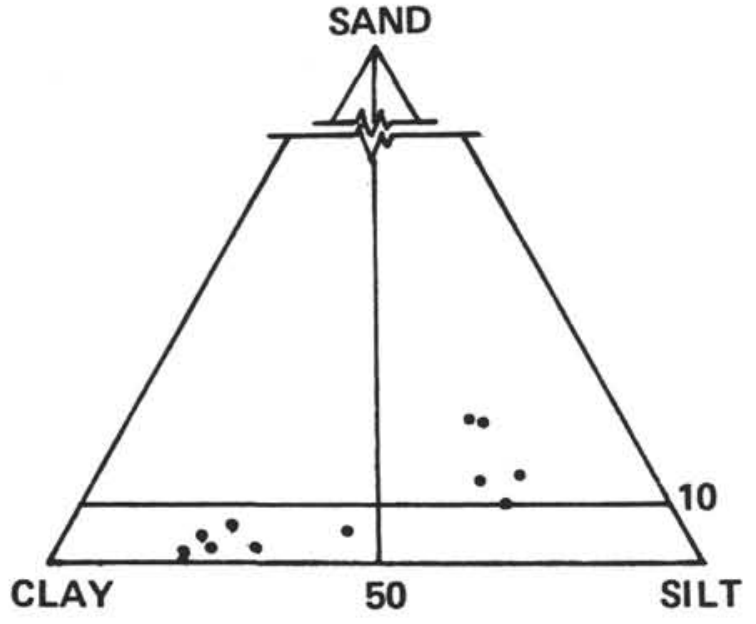

Figure 11. Grain size distribution of pelagic carbon sediments of Sites 44, 47, 48, 55 and 56.

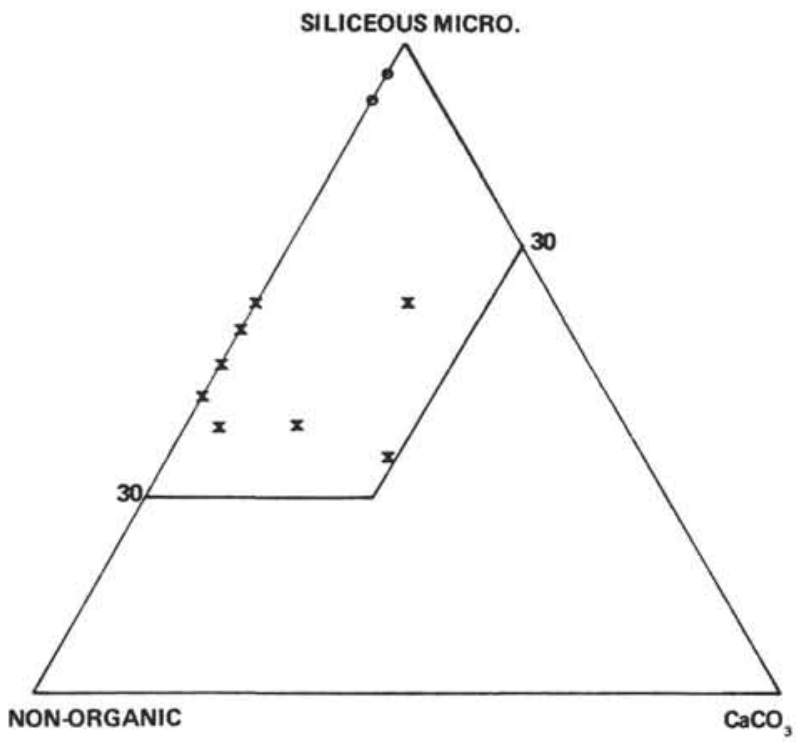

Figure 12. Approximate compositions, by volume, of some pelagic siliceous oozes recovered during Leg 6. Based on visual estimations made from smear slides of sediments from Sites 50, 53, 58 and 59. End members of the ternary diagram are siliceous microfossils, nonorganic components (clay minerals, volcanic glass, zeolites, etc.) and calcium carbonate (mainly as nannofossils). $X$ 's are radiolarian-rich oozes, small circles are diatom (Ethmodiscus) oozes.
Most of the siliceous oozes found on Leg 6 are noncalcareous (Figure 10) Exceptions are the Pleistocene radiolarian-diatom oozes of Hole 50.1 and the upper Oligocene radiolarian-spicule ooze of Hole 58.2 (Plate 12, Figure 6). Both contain significant amounts of calcite ( 45 to 87 per cent of the crystalline material) in the form of nannofossils, and in both instances the siliceous sediments are interlayered with nannoplankton marl oozes that also contain abundant opaline microfossils.

Origin

The occurrence and distribution of pelagic siliceous oozes found on Leg 6 correspond, in a general way, to the factors cited by Riedel (1959) as determining the contribution of siliceous organisms to marine sediments. He lists three such factors: (1) rate or productivity of these organisms (high in a belt around the equator and at high latitudes, low at intermediate latitudes), (2) rate of dilution by other components, and (3) rate of solution of siliceous skeletons on the sea floor. The latter has been subsequently treated in detail by Berger $(1968,1970)$ who showed this rate to be inversely related to water depth above 2000 meters, and additionally to be a function of water circulation patterns (see discussion by Kling in the summary of biostratigraphy for this report).

In a negative sense, siliceous oozes were not found in any of the shallower water sites on ridges or rises (Sites 44, 47, 48 and 55 through 57). These sites have thick sections of chalk ooze whose sedimentation must have diluted any contributions made by siliceous organisms; in addition, rates of dissolution for siliceous skeletons may have been generally higher at these sites in shallower water (see discussion by Kling, this report). Siliceous oozes also were not found in some areas where rapid sedimentation of volcanogenic material had a similar diluting effect (for example, Site 60; the upper Oligocene section at Site 57; and, most of the Miocene section at Sites 53 and 54). In the abyssal, basin-floor sites at intermediate latitudes (Sites 45, 46 and 52) they likewise were not encountered. This might be due to a combination of the low productivity of siliceous microplankton at these latitudes and the very low rates of deposition at these sites, all of which lie below the compensation depth for calcium carbonate. These two conditions would lead to total dissolution of slowly deposited siliceous microfossils while they were exposed for long periods at the sedimentwater interface, in the manner suggested by Riedel (1959) and Arrhenius (1963). Brown clays remain as a residuum.

Sites 49, 50 and 51 have Cenozoic siliceous oozes associated with brown clay, volcanic ash and marl ooze. All lie on or near the west flank of the Shatsky Rise, in areas where Cenozoic sedimentation rates have 
probably been intermediate between those on the higher parts of the Rise and those on the adjacent abyssal basin floor. They also lie well below the depths at which rates of opaline silica dissolution are high (Berger, 1968). At certain times during the Cenozoic (Miocene, Pleistocene) the depositional rates here were apparently low enough so that siliceous skeletons settling to the sea floor were not markedly diluted; but these rates must have been sufficiently high to insure relatively rapid burial of these microfossils and prevent dissolution on the sea floor, not only of the siliceous skeletons but also of the Pleistocene carbonate sediments of Sites 49 and 50.

The upper Miocene radiolarian ooze at Site 53 seems to represent a transitional phase of sedimentation between relatively rapid deposition of the thick OligoceneMiocene volcanic ashes below and relatively slow sedimentation of the brown clays above. This siliceous ooze was thus probably deposited at rates intermediate between the two, that is at rates precluding excessive dilution yet insuring rapid burial and preservation of siliceous microfossils.

Sites 58 and 59 have Oligocene, Miocene and Quaternary siliceous oozes. Both are deep water sites, below the present compensation depth for calcium carbonate, and both lie in low latitude areas of high plankton productivity. The combination of these two factors insures a rapid rate of supply of siliceous skeletons to bottom sediments yet prevents dilution by calcareous ones. An additional factor at Site 58 may have been the intermittently high rates of deposition as a consequence of periodic resedimentation from adjacent areas.

\section{CHERTS AND RADIOLARIAN MUDSTONES}

$$
\text { (R.E.G.) }
$$

\section{Introduction}

Cherts of radiolarian mudstones were encountered in 10 of the 17 sites drilled on Leg 6, as indicated in Table 5 . In the majority of cases the material recovered was angular, sand-to-cobble-size fragments (most commonly in core catcher samples) that represent pieces of nodules or beds broken up during the drilling (see Plate 9, Figure 10, and Plate 10, Figure 3); consequently the thickness and stratigraphic relations of the siliceous rocks to adjacent unlithified sediments remain largely uncertain. Drilling was apparently stopped by hard nodules or layers of chert at all of the sites listed in Table 6 .

Lithified siliceous sediments recovered on this leg are of Early Tertiary or older age. Small angular chert fragments are present in sediments of early Oligocene age at Site 44 , and possibly also at Sites 46 and 59. The siliceous rocks at the remaining seven sites (Table 6) are Cretaceous or older. As indicated elsewhere in this report (see sections on siliceous and carbonate sediments), there is a reciprocal age relationship between the occurrence of siliceous rocks (early Oligocene and older) and the presence of well-preserved siliceous microfossils (late Oligocene and younger). The data of Table 6 show no consistent relationship between the occurrence of siliceous rocks and depth below the sediment-water interface, which varies from 6 to 135 meters.

Two categories of siliceous rocks can be recognized based on lithology, type of associated unlithified sediments and bathymetric setting at the recovery site: (1) cherts, apparently nodular, associated with chalk ooze on rises and ridges, and (2) radiolarian mudstones and cherts found with brown clays at deeper water sites in abyssal basins.

\section{Cherts in Calcareous Sediments on Rises and Ridges}

This type of chert was recovered with upper Oligocene to middle Eocene, white nannoplankton chalk ooze on the Horizon Ridge (Site 44) and with similar sediment of Late Cretaceous to Late Jurassic age on the Shatsky Rise (Sites 47, 48, 49 and 50). Subbottom depths of the chert occurrences range from 12 to 130 meters. In most instances the chert fragments have thin white crusts of lithified chalk ooze, and in some specimens there are thin stringers and irregular mottles of lithified or partially silicified chalk ooze within the chert. These cherts are very hard, have vitreous to waxy lusters, and fracture conchoidally. Megascopically they resemble broken pieces of chert or flint nodules found in the British and other chalks, and indeed they may be fragments of nodular chert bodies broken apart during coring. Colors of the chert pieces are typically various shades of brown and gray, but, in addition, the core catcher sample of Core 2 at Site 50 has a variety of colors including reddish-brown, mottled red and yellowbrown, and white; as described in the site report, some of this varicolored chert may be pebbles from a conglomeritic layer. Other than slight color banding in some specimens, cherts in this category show no pronounced laminations or other indications of stratification.

Microscopically these cherts consist of very poorly preserved microfossil tests scattered through a fine-grained and poorly resolvable matrix of mostly cryptocrystalline quartz. In some cases the microfossils can be recognized as planktonic foraminifera with shell walls replaced by secondary silica (Plate 14, Figures 1, 2 and Plate 15, Figure 6), and in other cases they may be radiolarian remains. But in most cases the microfossils are not precisely identifiable and are present only as small, subspherical molds filled by lengthfast chalcedonic quartz (Plate 14, Figure 5), or as ghost-like outlines within a mass of cryptocrystalline silica. Some cherts from Site 44 contain scattered planktonic 
TABLE 6

Lithified Siliceous Rocks Recovered on Leg 6

\begin{tabular}{|c|c|c|c|c|c|}
\hline $\begin{array}{c}\text { Sample } \\
\text { Designation }\end{array}$ & Lithology & $\begin{array}{l}\text { Water Depth } \\
\text { (meters) }\end{array}$ & Age & $\begin{array}{l}\text { Depth Below } \\
\text { Sea Floor } \\
\text { (meters) }\end{array}$ & Remarks \\
\hline $\begin{array}{l}44.0-3-C C \\
44.0-5-C C\end{array}$ & Chert & 1478 & $\begin{array}{l}\text { Early Oligocene- } \\
\text { Middle Oligocene }\end{array}$ & $40-75$ & $\begin{array}{l}\text { Chert occurs in nannoplankton } \\
\text { chalk ooze on Horizon Ridge; } \\
\text { mainly brown to gray vitreous } \\
\text { chert, sometimes banded and } \\
\text { with white crusts of silicified } \\
\text { limestone (Plates: } 4 \text {, Figures } 1 \\
\text { and } 2 ; 5 \text {, Figure } 6 ; 7 \text {, Figures } 5 \\
\text { and } 6 ; 8 \text {, Figure 2). }\end{array}$ \\
\hline
\end{tabular}

45.1-2-CC Radiolarian $\quad 5508 \quad$ Late Eocene $49-58$

mudstone

Radiolarian mudstone with chert bands

$46.0-1-3$

$46.0-1-4$

$46.0-1-5$

46.0-1-6
Chert

$47.2-13$

47.2-14

48.2-2-4 Chert

49.1-2-CC

Chert

4282

Late Jurassic

(Tithonian)

50.0-2-1

50.0-2-2

50.0-2-3

$50.0-2-4$

50.0-2-5

50.0-2-6

50.0-2-CC
Mixed Oligocene-

Eocene and

Cretaceous

Late Cretaceous

(Maestrichtian)

Late Cretaceous

(Maestrichtian)

60-69

$6-15$

$110-130$ 2 ; and, 5, Figures 1 and 3). zeolitic brown clay in area of basinal topography (Plates: 4, Figures 3 and 4; 5, Figures 2 and $4 ; 6$, Figure $1 ; 7$, Figure 1 ; and, 8, Figure 1).

Associated with brown zeolitic clay in area of basinal topography; sediment thoroughly disturbed and mixed during coring. Light reddish-brown chert, in some cases interlayered with very light reddish-brown mudstone (Plates: 3, Figures 1 and

Recovered mainly as small angular pieces in nannoplankton chalk ooze on crest of Shatsky Rise. Color varies from brown to light brownish-gray.

Brown vitreous chert occurs as angular fragments in nannoplankton chalk ooze; probably were nodular bodies. Site on crest of Shatsky Rise.

12-20 Mottled yellow brown and light gray chert in nannoplankton chalk ooze. Site on west flank of Shatsky Rise (Plate 3, Figure $3)$.

42-45 Varicolored chert fragments (red, brown, yellow and white) occur in nannoplankton chalk ooze. Site on west flank of Shatksy Rise (Plates: 3, Figure $5 ; 4$, Figure 5; 5, Figure 5; and, 7, Figures 3 and 4 ). 
TABLE 6 - Continued

\begin{tabular}{|c|c|c|c|c|c|}
\hline $\begin{array}{c}\text { Sample } \\
\text { Designation }\end{array}$ & Lithology & $\begin{array}{l}\text { Water Depth } \\
\text { (meters) }\end{array}$ & Age & $\begin{array}{l}\text { Depth Below } \\
\text { Sea Floor } \\
\text { (meters) }\end{array}$ & Remarks \\
\hline $51.0-2-1$ & Chert & 5981 & Cretaceous & $124-132$ & $\begin{array}{l}\text { Reddish-purple chert with thin } \\
\text { bands and laminae of light } \\
\text { brown silicified limestone. Ap- } \\
\text { pears to be associated with } \\
\text { brown clay. Site in abyssal } \\
\text { basin west of Shatsky Rise } \\
\text { (Plates: } 3 \text {, Figure } 4 ; 8 \text {, Figures } \\
4,5 \text { and } 6 \text {; and, } 9 \text {, Figures } 3 \\
\text { and } 4 \text { ). }\end{array}$ \\
\hline $\begin{array}{l}52.0-7 \\
52.0-8\end{array}$ & $\begin{array}{l}\text { Radiolarian } \\
\text { mudstone with } \\
\text { chert bands }\end{array}$ & 5744 & Cretaceous & $55-65$ & $\begin{array}{l}\text { Laminated and shows composi- } \\
\text { tional banding from slightly } \\
\text { friable mudstone to hard chert, } \\
\text { as well as color banding from } \\
\text { dark brown to reddish-brown to } \\
\text { pale yellow. Occurs as scattered } \\
\text { angular fragments in brown } \\
\text { clay. Site is in abyssal basin east } \\
\text { of Bonin Trench (Plates: 3, } \\
\text { Figure 6; 6, Figures } 2 \text { through } \\
6 \text {; and, 7, Figure 2). }\end{array}$ \\
\hline $\begin{array}{l}52.0-9 \\
52.0-10 \\
52.0-\mathrm{CC}\end{array}$ & Chert & As above & Cretaceous & $65-69$ & $\begin{array}{l}\text { Site as above. Chert mixed with } \\
\text { brown clay, fish debris and } \\
\text { volcanic glass. }\end{array}$ \\
\hline $\begin{array}{l}59.2-6-1 \\
59.2-6-2\end{array}$ & $\begin{array}{l}\text { Silicified } \\
\text { mudstone }\end{array}$ & 5547 & Early Tertiary & $132-135$ & $\begin{array}{l}\text { Brown to reddish-brown, lam- } \\
\text { inated cherty mudstone recov- } \\
\text { ered as small fragments in highly } \\
\text { disturbed brown zeolitic clay. } \\
\text { Site is on abyssal basin floor } \\
\text { southeast of Marianas Trench. }\end{array}$ \\
\hline
\end{tabular}

foraminiferal remains with shell walls defined by secondary calcite, and some silicified foraminiferal tests in cherts from this site have interior geopetal infillings of cryptocrystalline and chalcedonic quartz (Plate 15, Figure 6). In the cherts of Site 49 (Plate 13, Figure 3), some microfossil (radiolarian?) interiors are filled by length fast chalcedonic quartz, others are unfilled, and still others have thin outer rims of isotropic amorphous silica and interiors of chalcedonic quartz. In no cases were the original opaline shell walls of siliceous microfossils preserved.

Under the electron microscope ${ }^{2}$ the cryptocrystalline quartz matrix in these cherts appears as a mosaic of

\footnotetext{
${ }^{2}$ The transmission electron micrographs of cherts and radiolarian mudstones in Plates 16, 17 and 18 are of replicas prepared by the two-stage method (Honjo and Fischer, 1965). Surfaces replicated were first ground and polished, then etched for 30 seconds in hydrofluoric acid fumes.
}

highly irregular grains that are peppered with numerous tiny fluid inclusions (Plate 17, Figures 3 through 6). This texture is somewhat similar to the "intermediate" type of chert surface described by Folk and Weaver (1952). However, the grain boundaries are less regular, inclusions are much more abundant, and variation in grain size is greater than in the "intermediate" cherts described and illustrated by Folk and Weaver. The electron microscope also shows occasional euhedral to subhedral crystals of authigenic calcite within the cryptocrystalline matrix, particularly in the partly silicified chalk ooze encrusting some of the cherts (Plate 18, Figure 2).

Thin sections across the contacts between chert and partly silicified chalk ooze show a spectrum of textures and preservation of microfossils (Plate 14, Figures 1,2). The chalk ooze tends to be cloudy and slightly brown due to the presence of fine-grained calcite, iron oxides 
and possibly clay minerals. Microfossils in the incompletely silicified chalk ooze tend to be replaced by secondary silica and show a range in morphological preservation from distinct to ghost-like (Plate 14, Figure 2 ). The chert is usually more transparent in thin section and contains only occasional ghost-like outlines of microfossils, most of the latter having evidently been obliterated during the silicification. Contacts between chert and partly silicified chalk ooze are typically ragged and irregular.

Some of the varicolored cherts from the core catcher sample of Core 2, Hole 50.0, have features not seen in the other cherts of this category. These differences include a somewhat coarser grained matrix, pronounced color and compositional mottling (Plate 13, Figure 5), and well-defined vein fillings of length fast chalcedonic quartz (Plate 15, Figure 5). As noted, these somewhat atypical cherts may be clasts of older chert incorporated within a conglomeritic layer.

Circumstantial evidence suggests that in most instances these cherts occur as lenticular, nodular bodies or very thin interlayers within unlithified chalk oozes, rather than as thick or continuous layers. In Holes 44.0, 47.2 and 50.0, drilling was apparently stopped by chert, but the cores taken above the terminal ones contain fragments of chert suggesting the core barrel penetrated thin chert stringers or small nodules. At Site 47, coring in Hole 47.1 was stopped, apparently by chert, at a subbottom depth of 100.6 meters; yet Hole 47.2, spudded nearby, cored to a subbottom depth of 129 meters before penetration was again stopped by chert, suggesting that the chert body at 100.6 meters must be very lenticular. Likewise at Site 48 , Hole 48.0 drilled to 84 meters subbottom before being stopped by chert, but a redrill attempt at the same site (Hole 48.1) could only penetrate to 49 meters before encountering impenetrable chert, and still a third attempt at the same site (Hole 48.2) cored to 72 meters where chert terminated the drilling; therefore, discontinuous chert bodies may exist at all three depths. Only at Site 49 were two separate holes ( 49.0 and 49.1 ) stopped by chert at approximately the same subbottom depth (19 to 20 meters).

Cherts in this category appear to have originated through diagenetic segregation of silica in solution and localized secondary silicification of chalk oozes. This origin is suggested by the presence of patches and mottles of incompletely silicified chalk ooze within chert, by microscopic textural features indicating replacement of calcium carbonate by silica, and by the lenticular character of the chert occurrences. Solution of opaline microfossil tests seems a possible source for the silica since the cherts lie within unlithified chalk oozes that contain no well-preserved opaline skeletons.
Radiolarian Mudstones and Cherts with Brown Clays in Abyssal Basins

Lower Tertiary and Cretaceous rocks in this category were recovered from Sites 45, 46, 51, 52 and 54 (see Table 6), at subbottom depths varying from about 6 meters to 135 meters. Water depths at all these sites are below 5500 meters. In contrast to the cherts of the first category, these siliceous rocks generally show laminations or other indications of stratification.

\section{Chert in Core 2, Hole 51.0}

This chert is somewhat atypical of the siliceous rocks in this group and petrologically seems more akin to those in the previous category except for the water depth at this site (5981 meters), its apparent association with brown clay, and the presence of conspicuous stratification. The chert is hard, has a waxy luster, fractures conchoidally, and is dark brown to reddishpurple. Fragments retrieved have crusts, small mottles and layers up to 5 centimeters thick of light brown, silicified chalk ooze. In thin section (Plate 13, Figure 4) a cryptocrystalline siliceous matrix is observed to contain scattered microfossils with about the same spectrum of preservation and infilling present in cherts of the first category (that is, some microfossil molds empty, others filled by length fast chalcedonic quartz). Within the layers of incompletely silicified chalk ooze are small amounts of calcite; calcareous microfossils in these layers are usually replaced by silica, but the interiors may remain unfilled or be partly filled by euhedral to anhedral crystals of secondary calcite that grew from the walls of the cavity (Plate 18, Figures 3, 4, 5; Plate 19, Figures 3, 4). Fish debris is abundant in some layers of the chert, some have small quartzfilled veins, and a few layers show disrupted laminations apparently due to soft sediment deformation on a small scale.

Like those in the first category, this chert appears to be the product of secondary silicification and replacement of a chalk ooze, but its apparent association with brown clays is puzzling. The sample may have been derived from a chert body that lies at the contact between brown clay and chalk ooze because the succeeding core (Core 3 of Hole 51.0) recovered a small amount of nannoplankton chalk ooze.

\section{Radiolarian Mudstones}

Brown to very pale reddish-brown radiolarian mudstones were recovered in small amounts at Sites 45, 46, 52 and 59 (Table 6), and in all cases were associated with brown clays or brown zeolitic clays.

Most of these rocks are somewhat friable and punky siliceous mudstones that have a porcelaneous luster and hackly fracture; they stand in contrast to the dense, hard and conchoidally fracturing cherts that have a 
waxy luster and are associated with chalk oozes. Also in contrast to most of those cherts, these siliceous mudstones show notable stratification that varies from millimeter-thick laminations to color and compositional banding on a centimeter scale (Plate 13, Figures 1,2). In one type of banding porcelaneous, pale reddish-brown mudstone layers alternate with hard, reddish-brown cherty bands three to five centimeters thick; the cherty bands sometimes interfinger with and include small patches of slightly porcelaneous mudstone, and they appear to represent areas of more intensive silicification of the mudstone.

Microscopically these mudstones look rather like the cherts previously described in that they consist of generally poorly preserved microfossils dispersed through a fine-grained matrix (Plate 13, Figure 6; and, Plate 14, Figures 4,5 ). There are, however, slight but significant differences. Foraminiferal shells, noted in some cherts (Plate 14, Figures 1, 2; and, Plate 15, Figure 5), were not seen in any of the mudstones studied. Preservation of microfossils is somewhat better in the mudstones. The exterior surfaces of some radiolarian molds show outlines of skeletal morphology (Plate 15, Figure 3); compare with the radiolarian mold from a chert illustrated in the upper left of Plate 14, Figure 5). In rare cases, even the original opaline silica walls of Radiolaria are preserved in the mudstones. In addition the mudstones contain identifiable sponge spicules (Plate 14, Figure 4), tests of nasselarian Radiolaria (Plate 14, Figure 3), and small amounts of fine-grained detrital minerals (quartz, feldspar, etc. and fish debris); these components are either extremely rare or (more commonly) absent in the cherts associated with chalk oozes.

Differences between the matrix of the mudstones and cherts are also evident. In thin section the nodular chert matrix is generally colorless, even grained cryptocrystalline quartz, whereas matrix in the mudstones is reddishbrown and is somewhat more poorly sorted due to the presence of iron oxides, clay minerals and small calcite crystals (Plate 13, Figure 2) along with fine-grained silica. The latter includes much silica of low birefringence; X-ray diffraction suggests that this is cristobalite. The nature of the matrix is more fully discussed in a following section.

Interior fillings of radiolarian molds show about the same variation noted in the cherts. Some are filled by spherulitic bundles of length fast chalcedonic quartz fibers that seem to have grown into void space (Plate 15, Figure 1); within some fillings of this type patches of mudstone are interspersed with chalcedonic quartz (Plate 15, Figure 2) in a manner suggesting caving into a cavity while quartz was being precipitated. Many radiolarian molds are hollow or partly hollow, and there is a tendency for filled and unfilled radiolarian molds to alternate in layers (Plate 13, Figures 1,2).
Upon close examination many of the unfilled molds are seen to be lined by spherulitic rims of amorphous silica, and some are completely filled by this material (Plate 15, Figure 3).

A few mudstone specimens recovered at Site 45 have small, quartz-filled veins that record a significant diagenetic episode. These veins vary in width from a few millimeters to a fraction of a millimeter, intersect the stratification at high angles, and offset laminae a few millimeters on opposite sides of the vein. Most seem to be discontinuous and wedge out or branch over distances of a few centimeters. Most are also partially filled by mudstone as well as by length fast, chalcedonic quartz (Plate 15, Figure 4). Precipitation in open space is suggested by the preferred elongation of quartz fibers roughly perpendicular to the vein walls, and by the general increase in crystal size away from the walls. This same pattern is evident around patches of mudstone within the vein, which suggests that, simultaneous with quartz precipitation in open cracks, pieces of mudstone were caving or being washed into these cracks. There, they became embedded in void-filling quartz and acted as surfaces from which outward growth of additional void-filling quartz fibers continued into the remaining void space. The origin of the fracturing is not known, but the features noted above indicate these rocks were somewhat lithified and brittle at a stage when they were still being affected by silica-saturated solutions.

\section{Nature and Origin of the Matrix in the Radiolarian Mudstones and Associated Cherty Bands}

As a glance at the photo-micrographs of Plates 13 (Figure 6) and 14 (Figures 3 and 4) will show, the finegrained matrix of the mudstones composes a half or more of the rock, thus the nature and source of this material becomes critical to an understanding of the genesis of the rock.

High magnification optical studies of the matrix do not fully resolve its composition, but suggest that it is a combination of silica with very low birefringence, amorphous silica, calcite crystals, iron oxides and clay minerals. X-ray diffraction indicates the most common crystalline materials in the rock are cristobalite, quartz, and calcite, in order of abundance. Most of the quartz probably resides in chalcedonic quartz kernels that fill radiolarian molds (Plate 15, Figures 1, 2, and Plate 16, Figure 1). The calcite occurs as small, subhedral to anhedral crystals (Plate 18, Figure 1) that are somewhat elongate and are scattered throughout the matrix. The cristobalite presumably lies chiefly in the matrix as the abundant low birefringence silica; this mineral appears on X-ray diffractograms as a somewhat broadened peak at about $22^{\circ} 2 \theta$ and closely resembles the prominent cristobalite peak recorded from porcelanites of the Monterey Formation by Ernst and Calvert (1969). 
Transmission electron micrographs of the mudstone matrix are shown in Plates 16 (Figures 4 and 5), 17 (Figure 1), and 18 (Figure 6). In contrast to the finegrained granular quartz of the nodular cherts (Plate 17, Figures 3,4 ), this matrix at high magnifications appears to be composed in large part of somewhat platy material that may be cristobalite. Grain boundaries within this platy material are for the most part poorly defined, and the grains in some specimens contain abundant small fluid inclusions (Plate 16, Figures 4, 5). Scattered within the platy material are spherulitic patches of inclusionrich chalcedonic quartz (Plate 16, Figure 1) that probably represent precipitation within microfossil molds; also present are silt- to fine-sand size grains of quartz, feldspar, etc., of probable detrital origin (Plate 18, Figure 6).

Ultramicroscopic textures of the centimeter-thick cherty bands within the mudstones contrast sharply with those of the mudstones themselves and also with the textures of nodular cherts associated with chalk oozes. In thin section these cherty bands consist largely of clots of fine-grained quartz with wavy extinction. Electron microscopy shows that these clots are bundles of fibrous chalcedonic quartz crystals having a very high density of fluid inclusions (Plate 16, Figures 2, 3, 6; and, Plate 17, Figure 2). Scattered through this quartz are fine to medium silt-size, subspherical aggregations of brown limonite, one of which is shown in the electron micrograph of Plate 16, Figure 6. Limonitic iron oxides have also secondarily replaced some radiolarian tests at various places in the cherty bands.

The matrix in both mudstones and associated cherty bands thus seems mainly the product of diagenetic reorganization of some original materials whose nature, at this stage, can only be speculated upon. In thin section these rocks closely resemble the bedded radiolarian cherts of geosynclinal terrains (for example, compare Plates: 13, Figure 6; 14, Figures 3 and 4; and, 15, Figure 3, with the photomicrographs of radiolarian cherts in Grunau, 1959; Fagan, 1962; and Garrison and Fischer, 1969). Both groups of rocks contain poorly preserved radiolarian remains in an abundant finegrained matrix, and the problem in both groups is to explain the origin of this matrix. This problem was discussed extensively with regard to radiolarian cherts of the Franciscan Formation by Davis (1918) who concluded much of the chert matrix must result from inorganic precipitation of silica. At the opposite pole is Fagan (1962) who attributed a wholly organic origin to Carboniferous radiolarian cherts of Nevada, and explained the matrix as due to diagenetic recrystallization of siliceous microplankton tests.

Possible insight to the origin of the matrix in these radiolarian mudstones is provided by observations on the radiolarian oozes recovered during Leg 6 . These are typically impure and poorly sorted mixtures of opaline radiolarian tests and sponge spicules, and other components such as clay minerals, iron oxides, zeolites, various types of volcanic debris, and, in some cases, calcareous nannofossils (see Plate 12, Figure 3 through 6). If sediment of this type were to become lithified, diagenetic modification of the nonorganic components could explain much of the mudstone matrix, whose poor sorting supports this interpretation. However, judging from the variation in preservation of siliceous microfossils (Plate 14, Figure 4, and Plate 15, Figure 3), a good deal of the silica in the matrix must also come from dissolution of opaline organic tests and later reprecipitation.

The siliceous mudstones herein described probably represent only the initial stages of the lithification process, and in these stages impure radiolarian oozes apparently have become reorganized into cristobaliterich, somewhat friable rocks. With increasing degrees of diagenesis, these mudstones are more intensively silicified and converted locally into cherty bands and patches characterized by a matrix rich in chalcedonic quartz. Still more advanced stages of diagenesis might convert the mudstones entirely into chert, in somewhat the same manner suggested by Bramlette (1946) and Ernst and Calvert (1969) for siliceous rocks of the Monterey Formation.

\section{Summary and Conclusions}

Siliceous rocks of two types were encountered on Leg 6: (1) cherts associated with pelagic chalk oozes at relatively shallow sites on rises and ridges-these cherts are apparently present as nodular bodies within unlithified chalk ooze; and, (2) well stratified radiolarian mudstones containing cherty bands and associated with brown clays in abyssal basins.

In cherts of the first type, absence of opaline microfossil tests in the associated chalk oozes suggests they may have been post-depositionally dissolved and thus supplied the silica that was concentrated by reprecipitation into the nodular form. Formation of these cherts involved silicification of chalk ooze. Their fine texture as seen with the electron microscope is a mosaic of tiny, very irregular and inclusion-rich quartz grains that are dissimilar to chert fabrics observed in other electron microscopic studies, such as by Folk and Weaver (1952). These cherts are very hard, fracture conchoidally, and have a waxy to vitreous luster.

The radiolarian mudstones are somewhat friable, have a hackly fracture and a dull to porcelaneous luster, and are brown to pale reddish-brown. Microscopically they resemble radiolarian cherts of geosynclinal belts in that they contain radiolarian remains dispersed through a fine-grained matrix. But this matrix evidently contains abundant cristobalite, which electron microscopy 
suggests is present in a platy form; and, although the radiolarian tests are for the most part strongly altered, some still retain their opaline shell walls. These facts lead to the suggestion that the mudstones represent the earlier stages of lithification of an impure radiolarian ooze in which many but not all opaline microfossil shells were dissolved, and the silica was reprecipitated largely as cristobalite. Small cherty layers and lenses in some mudstone specimens may record more advanced degrees of diagenesis whereby mudstone is partly silicified and cristobalite is converted to quartz. A continuation of this silicification might eventually transform the mudstone completely into chert.

Although this investigation has not pinpointed the processes responsible for genesis of the siliceous rocks described, it is evident that time rather than depth of burial is a more important controlling variable. The siliceous rocks are restricted to deposits of pre-late Oligocene age, but they occur as little as six meters beneath the sea floor.

\section{VOLCANIC ASH}

(A. C.P.)

\section{Introduction}

Thick sequences of Tertiary volcanic ash were drilled in the Philippine Sea (Sites 53, 54), and west side of the Mariana Trench (Site 60). Elsewhere ash occurs in the Tertiary interbedded with either brown clay (Sites 45 , $46,51,59$ ) or marl and chalk ooze (Sites 57, 58). The location of these sites is shown in Figure 1.

Evidence for continued volcanicity on a large scale back into the Mesozoic in the West Pacific is seen in Sites 45, 46, 51 and 59 .

The major constituents of the volcanic ash are volcanic glass (mostly colorless), pumice, palagonite, montmorillonite and feldspar.

The volcanic ash is usually gray, grayish-brown, greenishgray to dark gray and black in color.

The biogenic component of the volcanic ash is usually quite small and comprises calcareous nannoplankton and/or siliceous fossils (Radiolaria, sponge spicules and diatoms) depending on water depth and rate of sedimentation.

Evidence for a fast rate of accumulation of these ashes was seen in the Philippine Sea, Caroline Ridge area and Mariana Trench. Ash deposits of Middle Miocene age in the Philippine Sea (Site 54) accumulated at the rate of 100 meters per million years. On the west wall of the Mariana Trench (Site 60) ash collected at the minimum rate of 37 meters per million years. At Site 53 the sedimentation rate was at least 11 meters per million years in the Miocene, but is probably lower in the Pliocene. Similarly, at Site 54 there also appears to be a reduction in the accumulation rate of ash in the Pliocene. Minimum rates in the Pliocene in these two sites were 2 and 6 meters per million years, respectively. This slowing up of volcanic activity in the basin west of Iwo Jima Ridge during the Pliocene fits in with the development history of the Philippine Sea-namely that the Parece Vela Basin was growing rapidly in the Miocene and the Iwo Jima Ridge was a line of active volcanoes providing the apron of ash against its western side, while in the Pliocene the Mariana Arc was the active volcanic chain and the Mariana Basin to the west of it was the actively growing basin (see Chapter 20).

On the Caroline Ridge volcanic ash is interbedded with calcareous sediments in the Upper Oligocene and at Site 57 sedimentation rates were at least 37 meters per million years. In the Miocene and Pliocene a minimum rate of 11 meters per million years was measured.

\section{Texture}

The ash is predominantly of silt size. In Site 53 the upper part of the ash is silty sand and sandy silt size (median diameter 0.017 to 0.050 millimeter) but lower in the succession is of finer grain size (median diameter 0.011 to 0.020 millimeter), the sediment mainly being a silt and clayey silt. In Site 54 silt-size material predominates with only rarely sandy silt occurring. Median diameters of the sediment range from 0.012 to 0.035 with an average of 0.019 millimeter. In Site 60 a little clayey silt occurs in addition to the predominate silt class grade. In this site median diameters are lower than elsewhere with a range of 0.001 to 0.068 millimeter, the average being about 0.007 millimeter.

Volcanic ash from the Philippine Sea (Sites 53, 54) is generally quite well sorted, though exceptions do occur, the sorting coefficient ranging from 1.75 to 3.75 with an average of about 2.5. There is no skewness to the cumulative curve (Chapter 27). Ash from Site 60 is very poorly sorted (So $5+$ ) with a predominance to the fine fraction giving the curves a marked negative skewness (Chapter 27).

Ash from sites in the Pacific Basin proper is generally of finer grain size, mainly falling in the clayey silt and silty clay grades but this may be due as much to a dilution of the ash by other sediment as to an original feature. Furthermore, the greater age of the Pacific ashes has provided a much longer time for the alteration processes which tend to convert glass silt into claygrade material.

Split core sections of volcanic ash recovered on Leg 6 show a variety of well-preserved sediment structures. Deformation caused by the drilling operation has rarely affected cores of volcanic ash, in contrast to other 
sediments, because it is generally more compact and drier. The main features exhibited by the ash are color banding, graded bedding, cyclic sedimentation with other sediment types, burrow mottling, fine horizontal laminated bedding and also laminated cross-bedding.

Color banding is well developed in many of the volcanic ash beds and is primarily related to three factors: composition of the volcanic glass, admixture of other sediment and grain size. Most commonly the ash is dark gray in color but shows all gradations from black to light gray. Examples are given below.

In Sites 53 and 54 the coarser-grained ash is black and it grades up into dark gray and gray with decreasing grain size. Variations occur in 53.0-4-1 (Plate 29, Figure 2) where the ash forms brownish-black, grayishred and dark greenish-gray beds. In 53.0-4-2 the ash is greenish-black. In 54.0-7-2 the ash is gray-brown with black mottles, and in 54.0-7-3 gray-brown ash with black laminations passes down into light brown-gray ash.

At Site 57 the volcanic ash is interbedded with marl ooze in Cores 2, 3 and 4; at the base of each cycle black coarse silt- to sand-size ash occurs. This ash lightens in color as it grades up into a mixture of ash with marl ooze which is grayish-green and grayishyellow green. Volcanic glass in the ash beds comprises a mixture of olive green basaltic and transparent andesitic material.

At Site 60 the ash is again mainly dark gray to gray, and forms graded cycles with colors ranging from black through varying shades of gray to pale brown or olive gray in places. Ash of coarse sand size in Cores 1 and 2 forms thin beds, usually 1 to 2 centimeters thick, which are an unusual yellow-brown color.

The ash is mainly of silt size, but in a few places sandsize ash forms thin beds usually less than 5 centimeters thick, such as 53.0-1-2 (Plate 29, Figure 1), 53.1-2-4, 59.2-5-1 (includes fragments of chert in with the glass), 60.0-1-3, 60.0-2-2 (Plate 31, Figures 1, 2, 3). In 54.0-1-1 the sand-size ash forms a bed 50 centimeters thick.

Graded bedding of volcanic ash beds is quite common. The volcanic glass at the base of the graded beds is normally of fine sand or coarse silt size and grades up into mainly silt-size material. Good examples of graded bedding are seen in 54.0-1-3 (Plate 29, Figure 3), 57.1-2-2 (Plate 30, Figures 1, 2; and, Figure 13), 57.13-1 (Plate 30, Figure 3; and, Figure 13), 57.1-3-2 (Plate 31, Figure 3; and, Figure 13) and 60.0-6-4.

Cyclic sedimentation of volcanic ash and marl ooze is well developed in Holes 57.0 and 57.1. Particularly good examples are seen in 57.1-2-2 (Plate 30, Figures 1, 2; and, Figure 13), 57.1-3-1 (Plate 30, Figure 3; and,
Figure 13), 57.1-3-2 (Plate 30, Figure 4; and, Figure 13). Each cycle is generally 15 to 40 centimeters thick and comprises a sharp base on which black calcareous volcanic ash from 4 to 10 centimeters thick rests. This basal ash is strongly burrow mottled with paler colored material from above. The ash grades up into grayishyellow green, grayish-green, pale gray, and white nannoplankton marl ooze which ranges from moderately to slightly burrow mottled upwards. In a few places laminations are still visible, such as, 58 centimeters depth in 57.1-2-2. In Sections 1 and 2 of Core 1 in Hole 57.0, the burrow mottling has not obscured the finely laminated structure of the sediment. Breaks in the cyclic sequence are visible at two places (92 and 101 centimeters) in 57.1-3-1 (Plate 30, Figure 3). These may represent local erosion surfaces. The cyclic sequence at Site 57 then is a delicate balance between moderately strong currents bringing in sand- to silt-sized volcanic ash, and possibly capable of erosion in places, and the mainly calcareous pelagic sedimentation from above. At Site 60 the ash shows a well-developed cyclic sedimentation pattern in units 5 to 25 centimeters thick, such as, 60.0-2-2 (Plate 31, Figure 3; and, Figure 13) but in contrast to Site 57 the ash is not interbedded with a different sediment type. Each cycle starts off with a sharp black base grading up into dark gray, grayish-brown and finally pale brown ash. The grain size ranges from sand up to clayey silt at the top of each cycle.

Several of the volcanic ash cores show structures in the $\mathrm{X}$-radiographs-particularly bedding, micronodules and inclusions. Examples are shown in Plates 32 to 34.

\section{Mineralogical Composition}

The main minerals are described below; rare occurrences are listed under the regional headings.

\section{Volcanic Glass}

The volcanic glass occurs either as transparent or colored shards. The main varieties are listed here.

(1) Extremely thin, clear shards with thicker ridges running across many of them; this thicker ridge marks the point of contact with an adjacent glass bubble. The glass originally being highly vesicular but subsequently has been fragmented. The shards are highly angular and approximately equidimensional (Plate 35, Figure 1; and, Plate 37, Figure 4).

(2) Elongate clear glass shards with numerous tubular pipe-like vesicles (Plate 37, Figure 2).

(3) Thick clear glass fragments with varying numbers of vesicles (Plate 37, Figure 2).

(4) Glass shards similar to (1), but pale brown in color. 


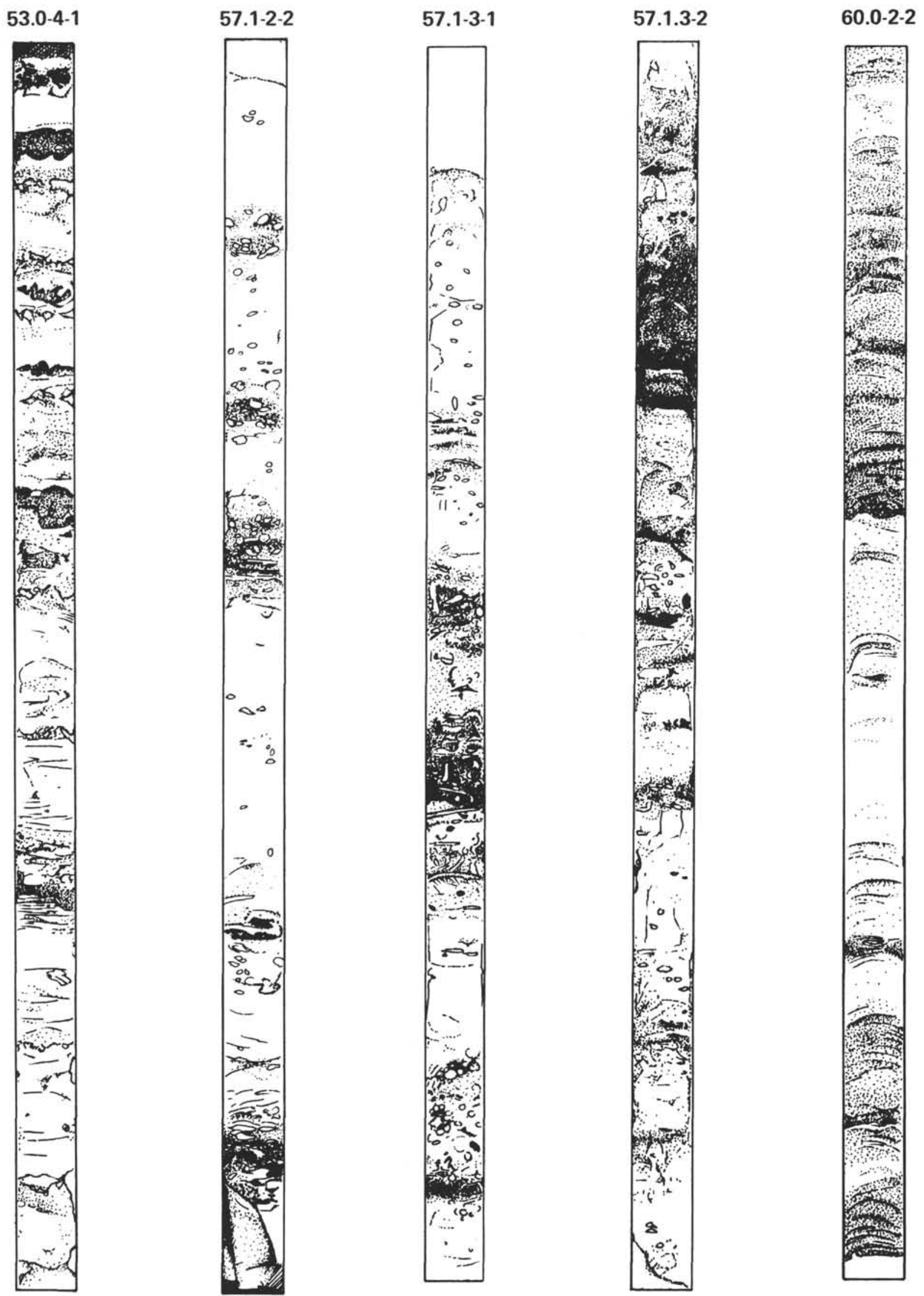

Figure 13. Drawings of core sections illustrating sedimentary structures in volcanic ash. 
(5) Thicker angular to subangular glass grains, many faceted, occasionally with conchoidal fractures, semitransparent, yellow pale brown, olive brown and olive green (Plate 36, Figures 1 through 5).

(6) Thicker but very small fine sand-size, subangular, equidimensional, opaque yellow, green, brown and red grains. These grains show signs of being transported rather than the product of a local eruption, as they are water worn and very well sorted (Plate 38).

Refractive indices of the transparent glass are about 1.53 to 1.55 , indicating that these glasses are of andesitic composition. The colored glasses usually have refractive indices of 1.58 to 1.60 , indicating that they are of basaltic composition (see Chapter 27).

\section{Pumice}

Pumice is very common in the sand fraction of the volcanic ashes and also occurs as pebbles as much as 25 millimeters in diameter. The pumice exhibits a great variety of colors ranging from white through olive brown and dark brown to black. Generally the darker varieties of pumice predominate. The pumice is usually well-rounded and circular in outline with a high proportion of vesicular space (Plate 38).

\section{Palagonite}

Palagonite is frequently abundant in places within the volcanic ash, but it is generally subordinate to glass and pumice. The palagonite occurs as rounded, though irregular, yellow or brownish-yellow soft grains. In thin section this mineraloid is isotropic.

\section{Inosilicates}

Pyroxene and amphibole occur in small amounts throughout most of the ash beds. The grains of both of these minerals are usually of fine sand to silt size. The pyroxene is mostly a pale green monoclinic variety. Both green and brown varieties of hornblende are predominant among the amphiboles. Rarely (Hole 60), hypersthene is also present. Epidote also occurs rarely in Holes 53 and 60.

\section{Tectosilicates}

Feldspars, predominantly plagioclase, are common amongst the fine sand and silt-size fraction of all of the volcanic ashes. The plagioclase usually occurs as subhedral grains exhibiting albite twinning, undulatory extinction and, in a few cases, pronounced zoning. Refractive indices indicate than in most cases the plagioclase is of andesitic (oligoclase) composition. Bytownite and sand-size grains were also seen in a few places (Cores 1 to 3, Hole 53.0). The grains are irregular, subangular, and in places subhedral with a short prismatic crystal form; cleavage is sometimes visible (Plate 38).
Small angular grains of quartz were seen in Holes 53 and 54 . However, they only make up a very small proportion of the sand and silt fraction.

\section{Oxides}

Oxides of iron and manganese are usually common throughout the sand and silt fractions of all volcanic ashes. Limonite is the most common iron oxide, and hematite was recorded in a few cases. Magnetite occurs rarely either as isolated octahedra or as extremely small octahedra within glass fragments. Irregular grains of magnetite are more common. Lithified ash pebbles within these sediments also frequently contain small specks of magnetite.

\section{Phosphates}

Skeletal fish fragments in the form of bones, scales and teeth are nearly always common in the sand fraction of the volcanic ashes. Fish otoliths are very abundant in the sand fraction of Cores 9 and 10 in Hole 53. Apatite occurs very rarely in Hole 53.

\section{Cosmic Spherules}

Small black ferromagnesian spherules occurring in Core 6 of Hole 59.2 are thought to be of cosmic origin.

\section{Rock Fragments}

Fragments of lithified sediment and volcanic rocks occur as pebbles and sand-size grains in many of the volcanic ashes. The main occurrences are listed under the regional headings.

\section{Biogenic Components}

Radiolaria, radiolarian spines and sponge spicules are usually common in the sand fraction of all volcanic ashes. Diatoms and foraminifera (both planktonic and benthonic) also occur, but are far less common.

\section{Philippine Sea (Sites 53 and 54)}

Volcanic ash from these two sites shows interesting variations on the X-ray diffraction data. However, caution is needed in interpreting these results because of the highly amorphous nature, particularly in Site 54, of the sediment. In Site 53 the amorphous content is usually 70 to 80 per cent, and in Site 54 usually 85 to 95 per cent.

From 12 to 80 meters depth in Site 53, plagioclase is the dominant mineral (of the crystalline fraction) and ranges from about 80 to 100 per cent. In a few places the plagioclase content is reduced to about 50 per cent, because of a corresponding increase in calcite (calcareous microfossils). Quartz occurs sporadically and ranges from about 5 to 15 per cent in Site 53. 


\section{PLATE 29}

Structures Visible in Core Sections of Volcanic Ash from Philippine Sea

Figure 1 Hole 53.0-1-2:

Middle Miocene.

Partially lithified silty gray volcanic ash, finely laminated in places and contains a few beds (78 to 80 $\mathrm{cm}, 92$ to $95 \mathrm{~cm}$ ) of darker sandy ash beds.

Figure 2 Hole 53.0-4-1:

Early Oligocene to early Miocene.

Beds of grayish-red, greenish-gray, and brownishblack ash. Darker beds show slump features.

Figure 3 Hole 54.0-1-3:

Early Middle Miocene.

Dark gray ash with graded beds $(76$ to $82 \mathrm{~cm})$ and laminations of (103 to $108 \mathrm{~cm}$ and 115 to $131 \mathrm{~cm}$ ) black ash. Note fractures in bedding $(116 \mathrm{~cm})$ and more strongly lithified ash (143 to $149 \mathrm{~cm}$ ). 

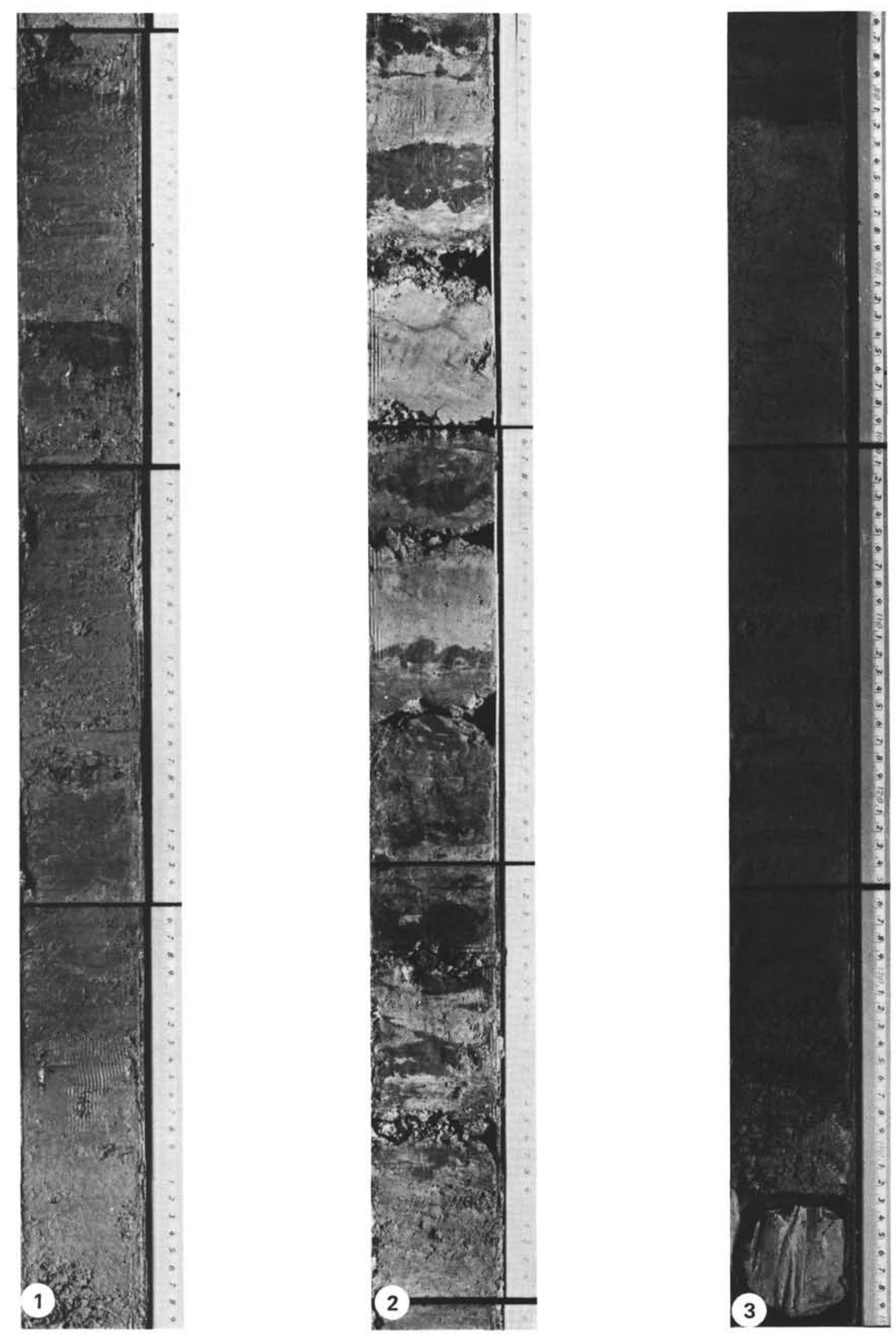
PLATE 30

Structures Visible in Core Sections of Late Oligocene Volcanic Ash and Chalk/Marl Ooze from Caroline Ridge

Figures 1 and 2 Hole 57.1-2-2:

Shows cyclic bedding each cycle ranging from 15 to $40 \mathrm{~cm}$ thick (most commonly $20 \mathrm{~cm}$ ). At base is black sandy/silty volcanic ash which is strongly burrow mottled, ash grades up into finer grade calcareous ash and color lightens with increasing admixture of chalk/marl ooze, burrow mottles also decrease in number upwards in each cycle. Top of cycle consists of light grayish-green white pelagic carbonate.

Figure 3

Hole 57.1-3-1:

Similar to Figures 1 and 2. Note erosion surfaces at 92 and $100 \mathrm{~cm}$.

Figure 4 Hole 57.1-3-2:

Similar to Figures 1, 2 and 3, but dark ash forms thicker graded beds and probably deposited so rapidly that extensive burrow mottling did not have time to form. 

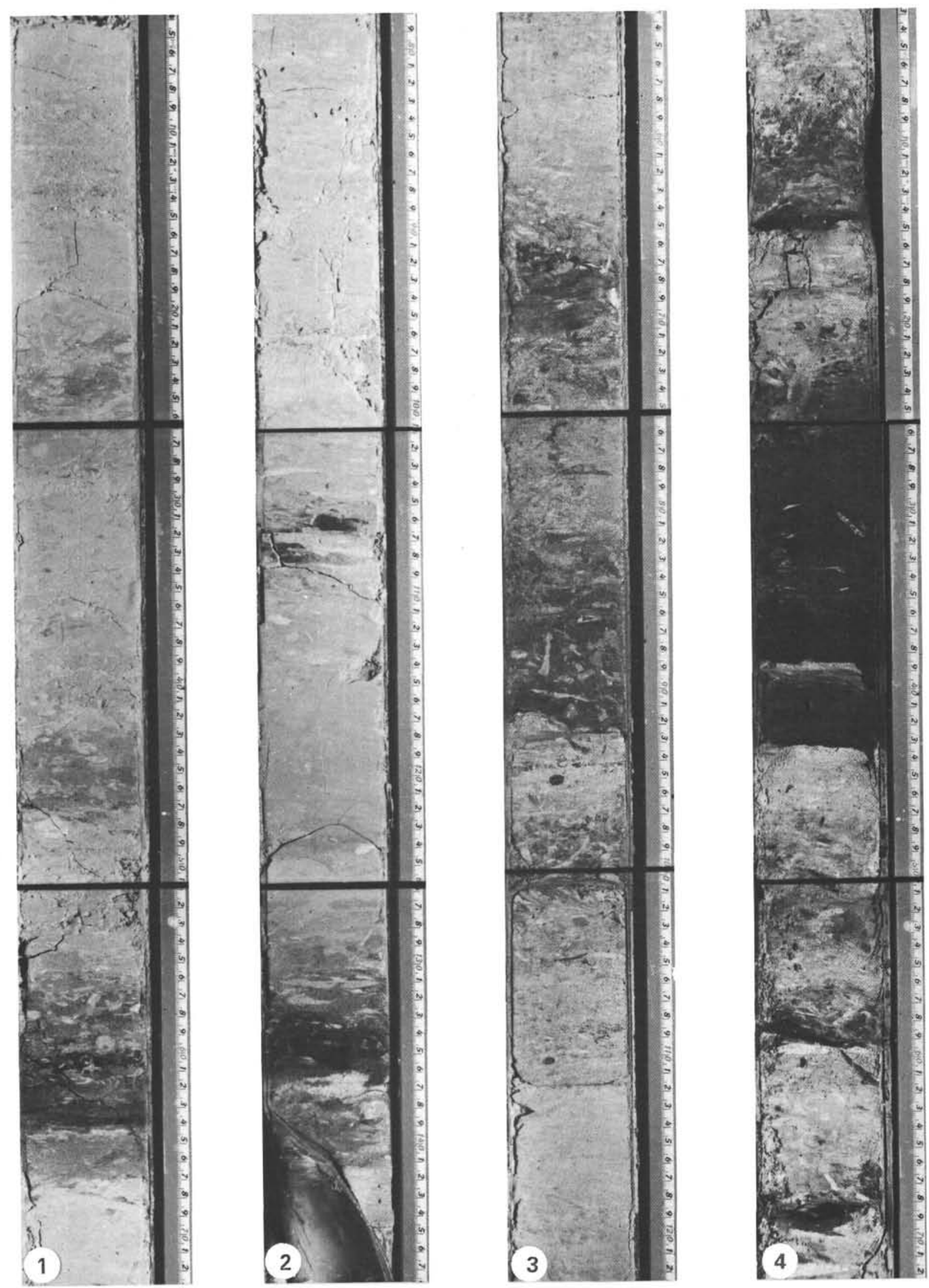
PLATE 31

Structures Visible in Middle Miocene Volcanic Ash and Marl Ooze from Wall of Mariana Trench

Figures 1 and 2 Hole 60.0-1-3:

Pale brown to gray brown marl ooze with dark gray graded and laminated ash beds. Figure 2 shows possible erosive base to dark ash bed $(126 \mathrm{~cm})$.

Figure 3 Hole 60.0-2-2:

Thick graded and laminated dark gray ash bed of sand size passing up into pale brown, grayish-brown laminated calcareous silty ash.

Figure 4 Hole 60.0-5-3:

Laminated dark gray and gray to light gray ash. 

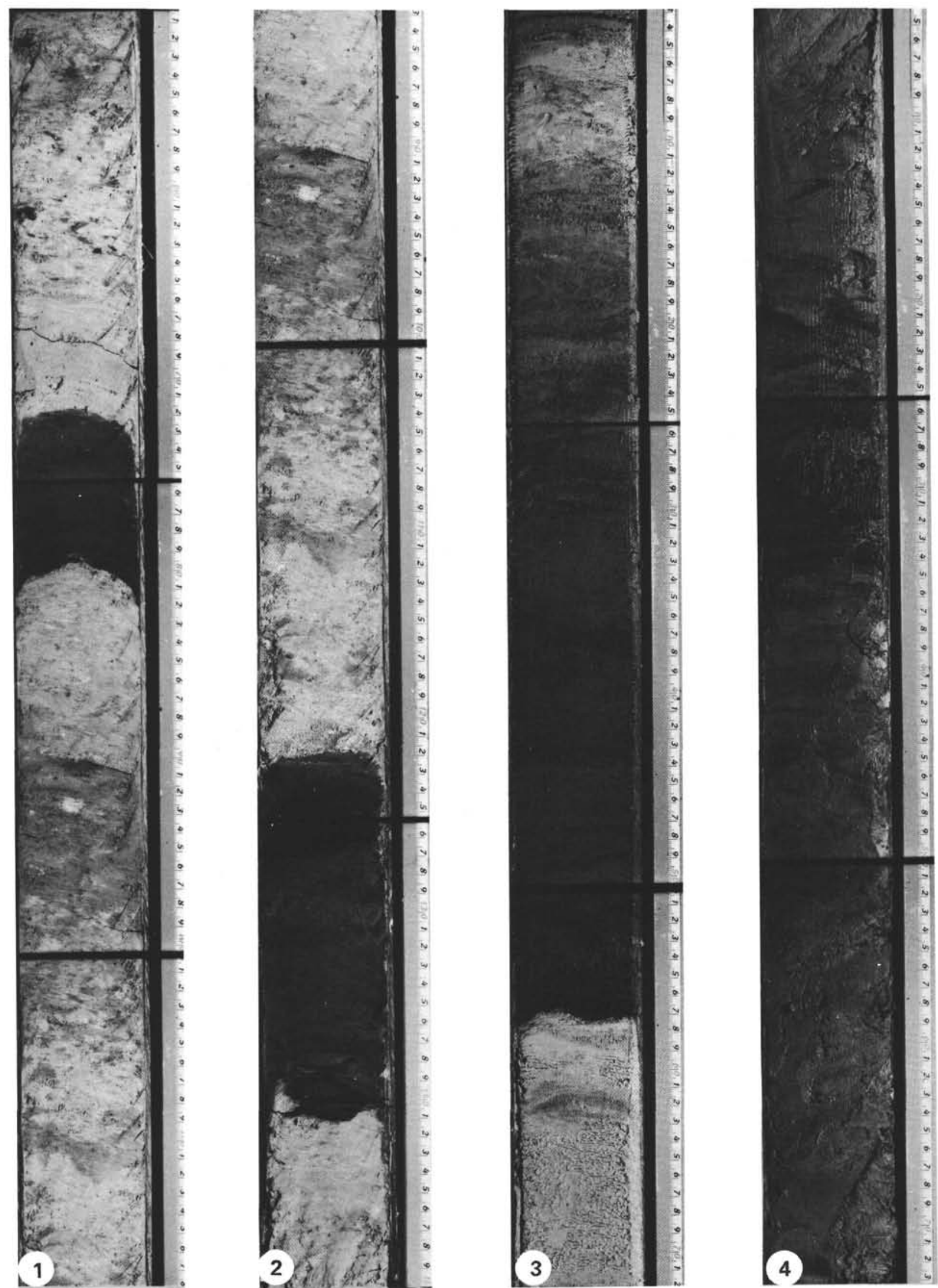
PLATE 32

X-radiographs of Miocene Volcanic Ash and Clay with Ash in Phillipine Sea

Figure 1 Hole 53.2-1-1, 113-142 cm: Clay with abundant glass fragments resting on ash radiolarian ooze with clay.

Figure 2

Hole 53.2-1-1, 78-112 cm:

Clay with manganese nodules resting on clay with abundant glass fragments.

Figure 3 Hole 53.0-1-3, 75-109 cm:

Bedded volcanic ash resting on clayey ash. 

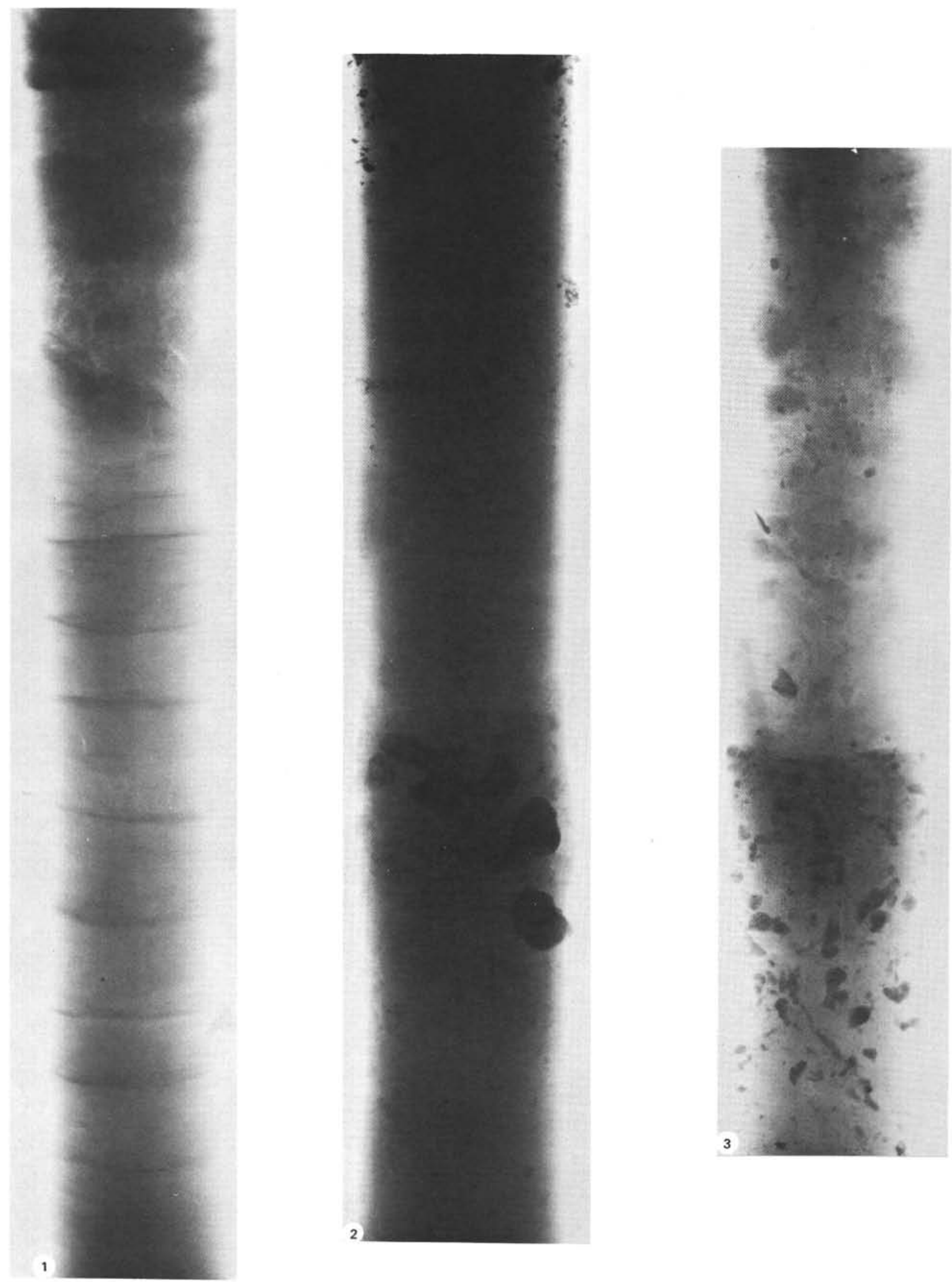


\section{PLATE 33}

X-radiographs of Late Miocene Volcanic Ash from Phillipine Sea

Figure 1 Hole 53.1-2-1, 85-109 cm:

Volcanic ash contains numerous pebbles of pumice and glass fragments.

Figure 2 Hole 53.1-2-3, $45-73 \mathrm{~cm}$ :

Volcanic ash with pumice and glass fragments passing down into clay (dark inclusions rare).

Figure 3 Hole $53.1-3-1,4-30 \mathrm{~cm}$ :

Watery volcanic ash containing abundant pebbles of pumice and lithified ash. 

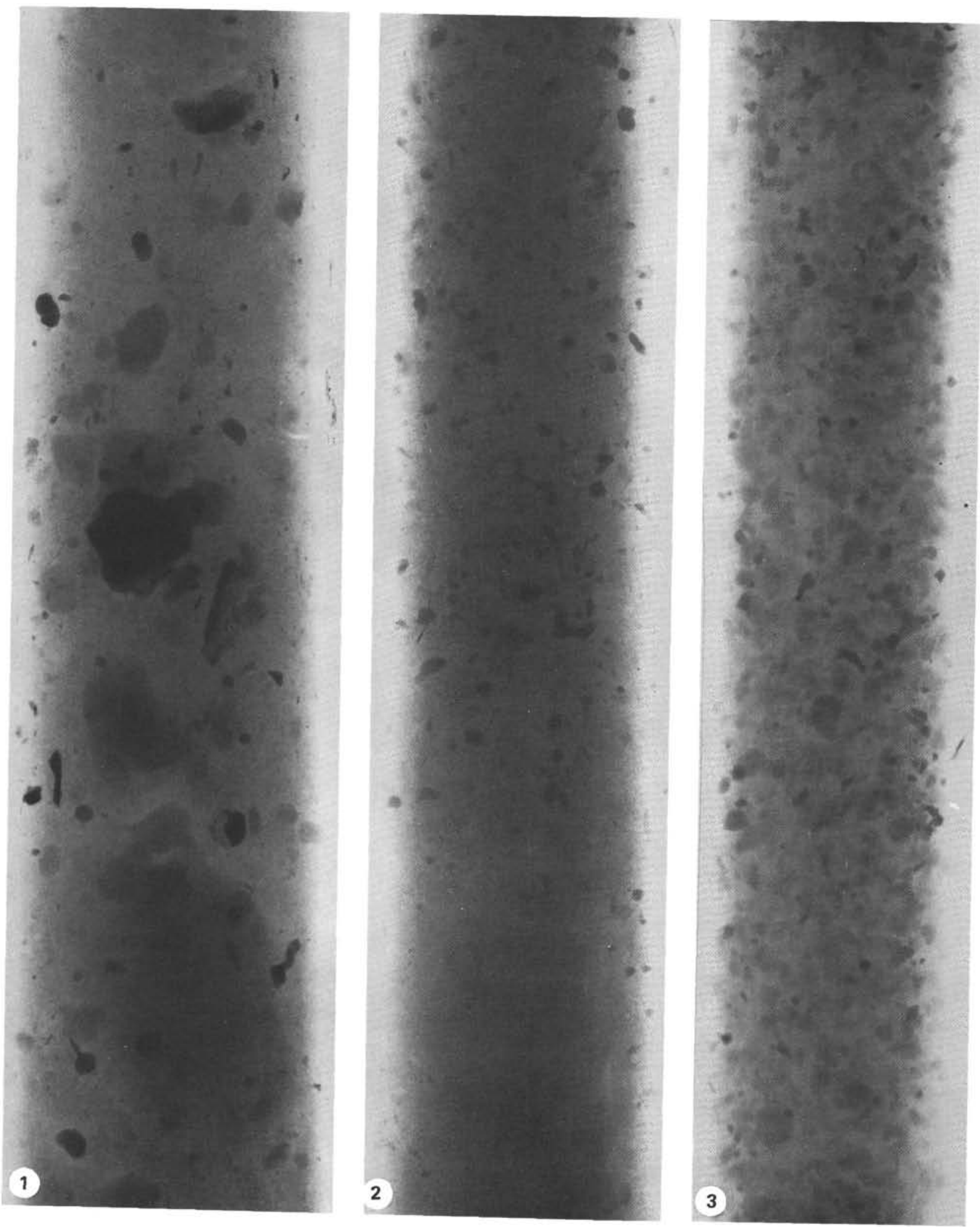


\section{PLATE 34}

X-radiographs of Miocene Volcanic Ash from Philippine Sea

Figure 1 Hole 54.0-1-1, 39-72 cm:

Coarse sand-size volcanic ash passing down to finer silt-size ash.

Figure 2 Hole 53.1-3-5, 77-106 cm:

Laminated volcanic ash. 

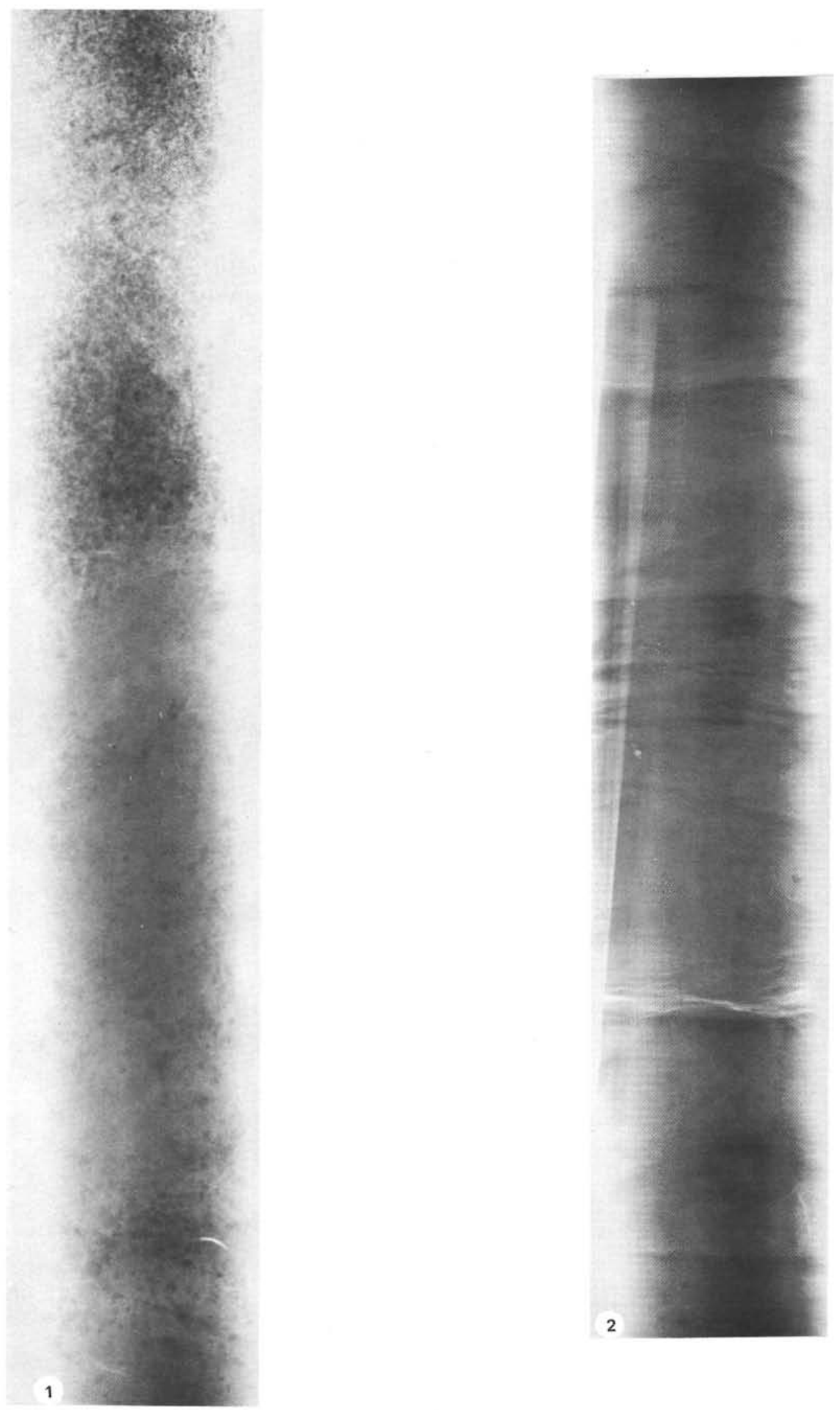


\section{PLATE 35}

Smear Slides of Glass Shards

Figure 1

Figure 2

Figure 3
Sample 53.0-3-1, $79 \mathrm{~cm}$ (plain light, $\times 28$ ):

Fragments of bubble shards in brown clay.

Sample 49.0-1-1, $30 \mathrm{~cm}$ (plain light, $\times$ 28):

\section{Pleistocene.}

Clear shards and shards with tubular vesicles and inclusions in brown clay with volcanic ash.

Sample 47.2-1-4, $131 \mathrm{~cm}$ (plain light, $\times 28$ ):

Pleistocene.

Mostly clear shards in chalk ooze. 

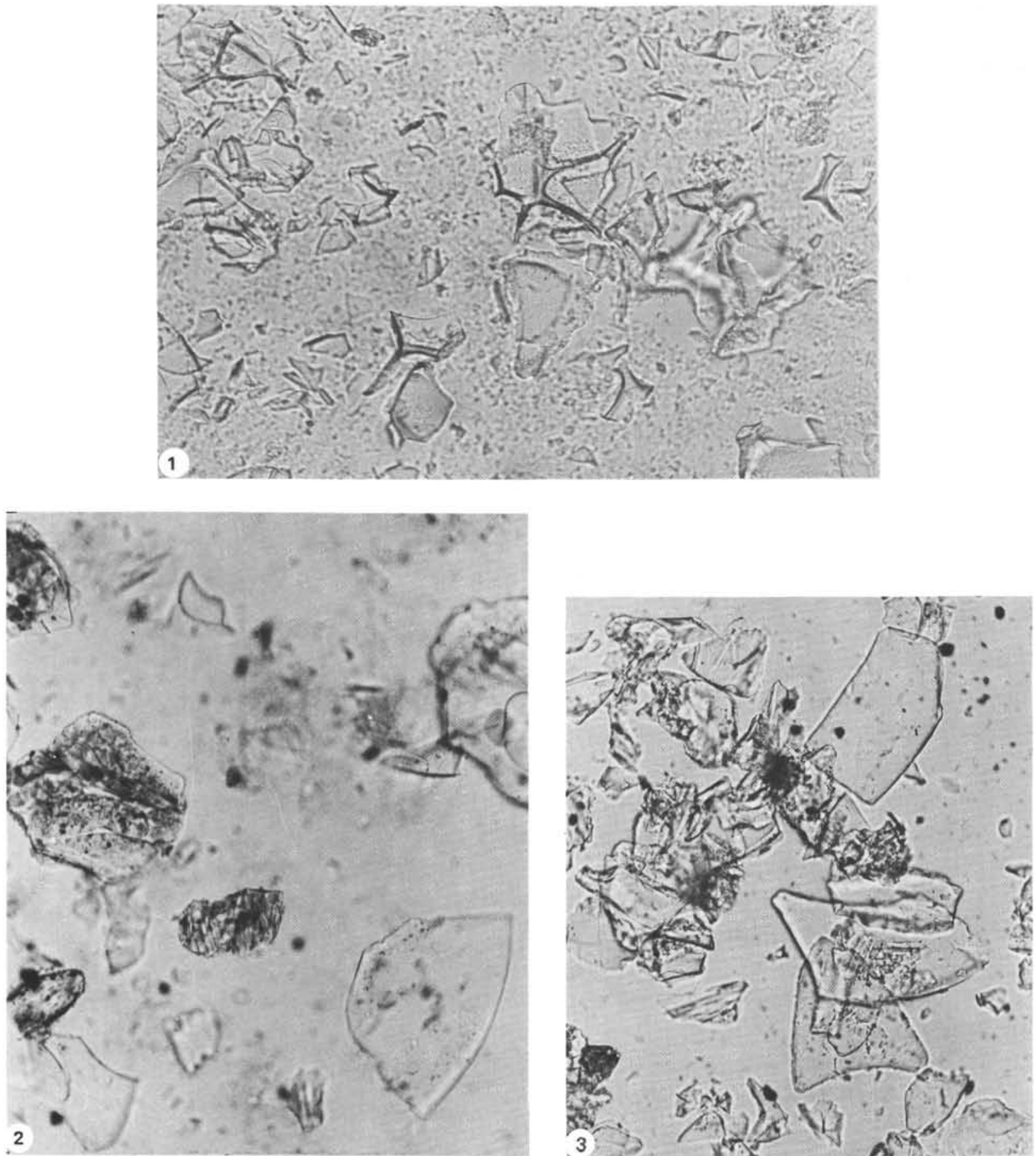
PLATE 36

Smear Slides of Late Late Oligocene Volcanic Ash from Caroline Ridge

Figures 1 to 5 Sample $58.2-1-4,143 \mathrm{~cm}$ (plain light, $X 28$ ).

Note: colored glass fragments (olive green to olive brown, R.I. > balsam), transparent glass fragments (R.I. < balsam), common pyroxene and plagioclase, also sponge spicules, Mannoplankton, foraminifera and some opaque minerals. 

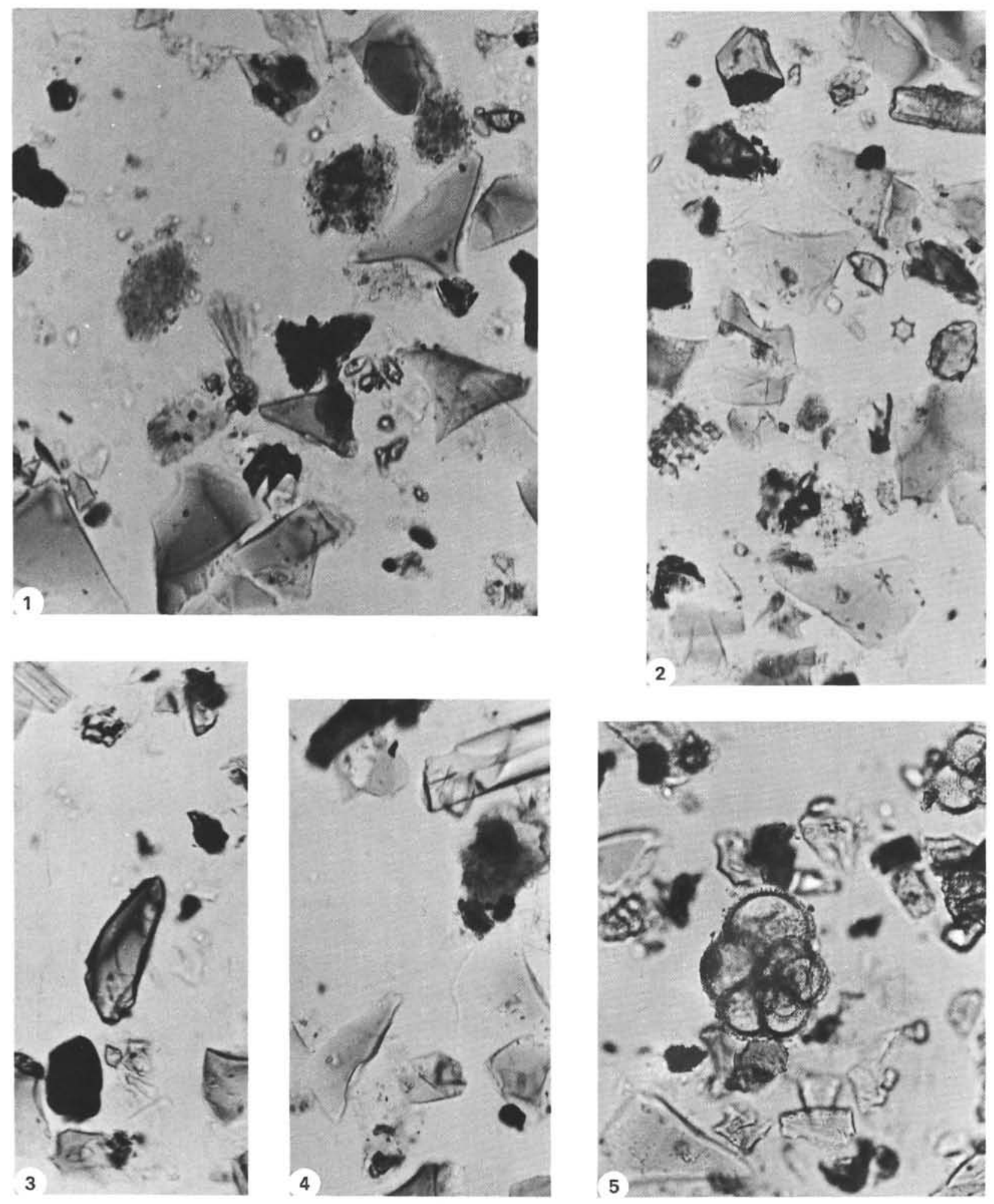


\section{PLATE 37}

Smear Slides and Electron Scan of Volcanic Ash from Phillipine Sea

Figure 1 Sample 53.0-4-2, $5 \mathrm{~cm}$ (plain light, $\times 28$ ):

Early Oligocene to early Miocene.

Note: large amphibole grain and altered glass fragments.

Figure 2 Sample 54.0-6-2, $70 \mathrm{~cm}$ (plain light, $X 17$ ):

Early Middle Miocene.

Glass fragments with tubular vesicles and inclusions (R.I. $<$ balsam).

Figure 3 Sample 53.2-1-4, $20 \mathrm{~cm}$ (plain light, $\times 28$ ):

Late Miocene.

Mixture of volcanic ash and siliceous ooze containing radiolarian fragments, sponge spicules, nannoplankton, altered glass, feldspar, mica and opaque minerals.

Figure 4 Sample 53.1-2-1, $145 \mathrm{~cm}$ (electron scan, $X$ 100):

Late Miocene.

Sand fraction of volcanic ash comprising pumice, bubble shards, shards with tubular vesicles, and rare feldspar. 

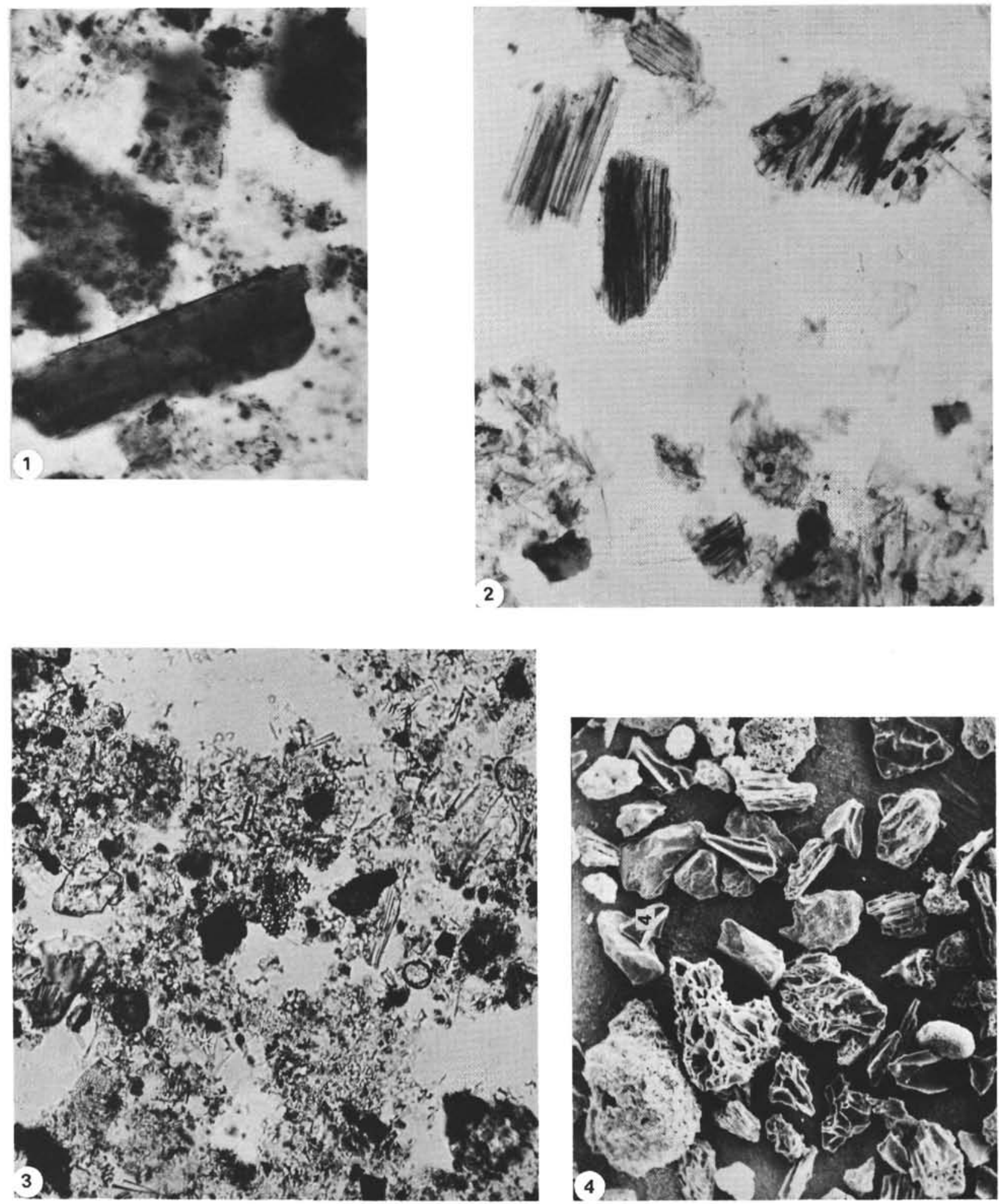
PLATE 38

Electron Scan Photographs of Sand Fractions from Volcanic Ash and Brown Clay

Figure 1

Sample 52.0-1-1, $22 \mathrm{~cm}$ (X 100).

Miocene to Middle Pleistocene.

Sand fraction recovered from clay/ash admixture comprising mostly bubble shards and some pumice.

Figure 2 Sample 53.1-2-1, $145 \mathrm{~cm}$ (X 1000):

Late Miocene.

Shows details of pumice fragment.

Figure 3 Sample 52.0-3-5, $1 \mathrm{~cm}(\times 100)$ :

Miocene to Middle Pleistocene

Sand fraction recovered from clay comprises pumice and feldspar.

Figure 4 Sample 54.0-6-1, $145 \mathrm{~cm}(\times 100)$ :

Early Middle Miocene.

Sand fraction recovered from ash comprising bubble shards, shards with tubular vesicles, pumice, and marl sponge spicules.

Figure 5 Sample $60.0-3-2,121 \mathrm{~cm}(\times 100)$ :

Middle Middle Miocene.

Sand fraction recovered from ash comprising wellsorted, water worn transparent and colored glass and pumice. 

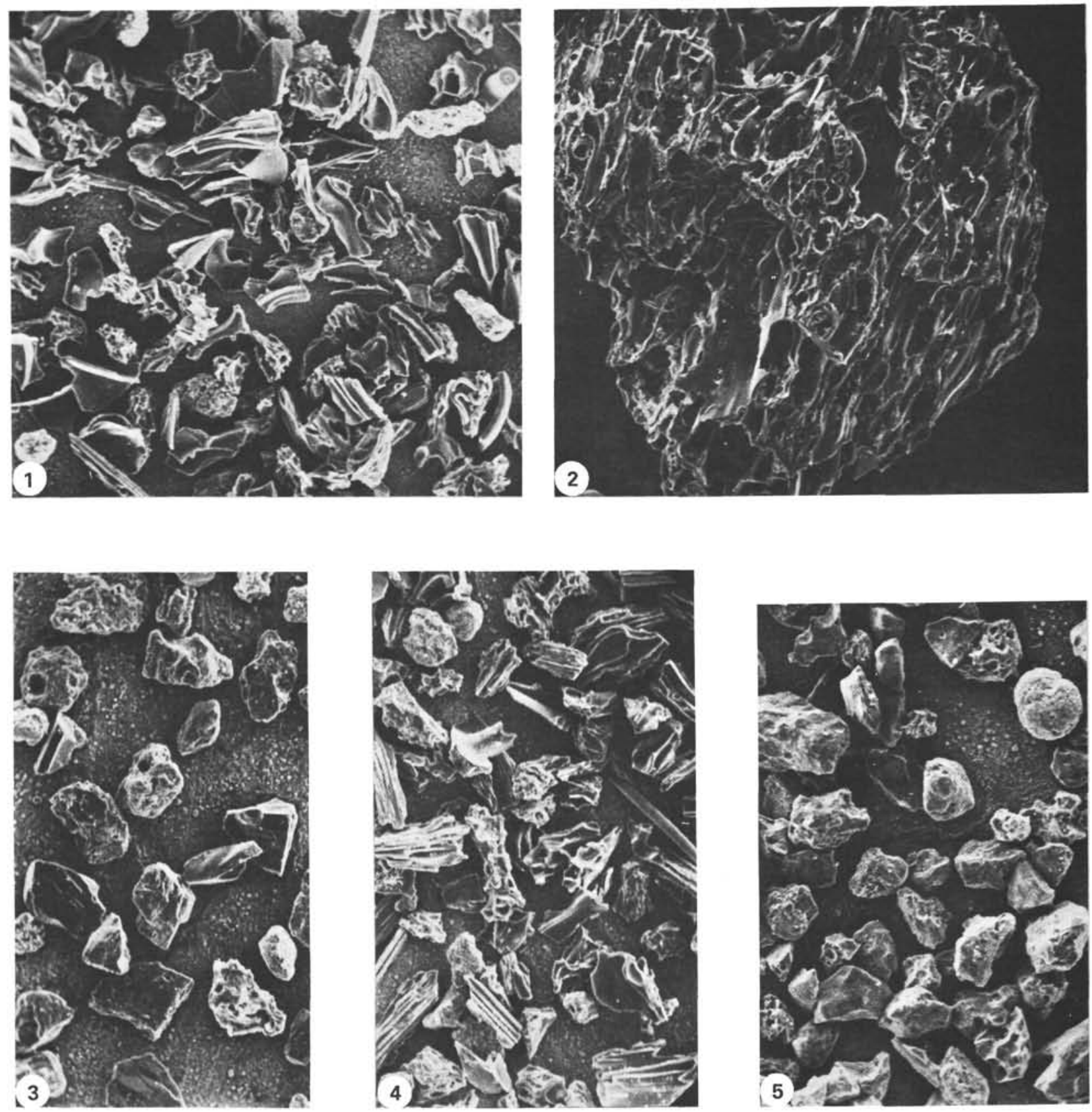
From 99 to 197 meters depth in Site 53 montmorillonite is dominant (usually over 80 per cent) while plagioclase and potassic feldspar occur in some places in amounts usually less than 15 and 10 per cent, respectively. Calcite occurs in places, and there proportionally reduces the montmorillonite content.

In Site 54 montmorillonite is dominant, and here all samples were below 83 meters depth, thus giving a situation similar to that for Site 53. The montmorillonite content is usually over 60 per cent. Plagioclase ranging from 10 to 15 per cent is always present, and calcite in amounts usually less than 25 per cent occur in most samples.

Petrographic examination of the samples indicate that the quartz content is very low-in most cases probably less than 1 per cent.

The sand fraction from Core 3, Hole 53.0, contains abundant subhedral clear plagioclase crystals.

The volcanic glass shows a variation in composition with age. Upper horizons in the Philippine Sea show a predominance of colorless acid volcanic glass (R.I. 1.504-1.510). The major portion of the ash succession shows a dominance of pale green acid glass (R.I. 1.5101.555). In addition to the volcanic glass, pumice is abundant and palagonite also occurs. Pebbles of pumice 1 to 3 centimeters across are particularly common throughout the ash in Hole 53. In Hole 54, Core 6, pebbles of pumice form a distinct bed 10 centimeters thick.

Monocline and orthorhombic pyroxene in about equal amounts predominate among the heavy minerals, although with depth the ratio increases to about $2: 1$. A few grains of epidote, garnet, amphibole, olivine, aegerine, rutile, celesto-barite and mica were also seen in some samples.

Grains of lithified chalk frequently occur in the ash when it is interbedded with similar sediment. For example, in Core 6 of Holte 53.0, pink and red carbonate grains are presumed to have been derived from metamorphosed limestone of similar color which occurs nearby in the succession. More commonly, white fragments of lithified chalk occur in the ash when it is interbedded with similar sediment (for example, Core 1 of Hole 53.1).

Chert occurs as angular fragments within the ash close to beds of the same sediments. Tuffaceous rocks occur in the ash in Holes 53 and 54; and, lithified ash fragments are common throughout Hole 53.

Rounded grains of green to brown basalt?, in which feldspar laths are still visible, occur in Core 7 of Hole
53.0. The strongly altered and limonized rock fragments in Core 2 of Hole 54.0 are thought to be of volcanic origin.

\section{Mariana Trench (Site 60)}

From about 130 meters depth down to 350 meters, this site comprised volcanic ash. The dominant constituents being silt- to sand-sized volcanic glass and pumice. Details of the variation in glass content are given in Chapter 27. In general the glass is colorless to pale brown (also pale green according to Lisitzin, Chapter 27 ), being mainly of intermediate (andesitic) composition.

At Site 60, amorphous values range from 40 to 90 per cent. Of the crystalline material, plagioclase or calcite are dominant, the two minerals being antipathetic to each other here. Usually these two minerals together make up 80 to 90 per cent of the crystalline fraction. The volcanic ash is interbedded with nannoplankton marl ooze in places, thus giving high calcite values. Quartz occurs in most samples, but in small amounts (1 to 16 per cent). Potassic feldspar was recorded only in the interval 350 to 350.4 meters, and it ranged from 8 to 53 per cent.

In a few samples montmorillonite was abundant (30 to 70 per cent), indicating a greater breakdown of the volcanic constituents in some horizons.

In Section 3 of Core 9 (350 meters) the ash is coarsegrained sand with some silt. It is bedded in units 2 to 4 centimeters thick of varying colors ranging from black through dark olive gray to olive gray. X-ray diffraction of olive gray beds at 77 and 89 centimeters yielded 57 and 53 per cent erionite (a zeolite). A sample of dark olive gray ash yielded 17 per cent erionite; and, in black ash at 109 centimeters none was recorded.

This is the first recorded occurrence of erionite in marine sediments. Formerly this mineral was also considered rare on land, but according to Deer et al. (1963), this fibrous zeolite is "almost certainly much less rare than previously supposed." In most deposits where erionite forms a large proportion of the rocks, it is considered to represent the alteration products of acidic vitric ash which accumulated in Cenozoic lakes.

Black ore minerals are occasionally common in the heavy mineral fraction; for example, the core catcher sample from Core 4 contained about 50 per cent of ore minerals in the heavy fraction. Rare grains of garnet, epidote, chlorite, biotite, apatite, rutile and mica were also seen in a few samples from this hole.

Montmorillonite only occurs in two samples from Section 3, Core 9, but here in large amounts. The sediment in both cases is a sandy ash very similar to that which 
contained erionite in large amounts, however, there is a color contrast as the samples with high montmorillonite are much darker in color.

Potassic feldspar only occurs at the very bottom of Site 60 where in three samples it ranged from 8 to 53 per cent of the total mineral content.

Heavy minerals mainly include pyroxenes, with lesser amounts of amphibole and rare epidote, garnet and glauconite.

\section{Chemical Composition}

\section{Trace Elements, Manganese and Titanium}

Core averages of trace elements detected in volcanic ash are given in Table 7. Samples from all three sites are generally much lower in trace elements than the brown clays and other averages given in Table 3. Sites 54 and 60 have very similar values, but ash from Site 53 contains greater concentrations of chromium, vanadium, nickel and copper.

TABLE 7

Core Averages of Trace Elements in Volcanic Ash in Northwest Pacific

\begin{tabular}{rrrrrrrrrrr} 
Site & $\mathrm{Mn}$ & $\mathrm{Ti}$ & $\mathrm{Cr}$ & $\mathrm{V}$ & $\mathrm{Ni}$ & $\mathrm{Co}$ & $\mathrm{Zr}$ & $\mathrm{Cu}$ & $\mathrm{Pb}$ & $\mathrm{Mo}$ \\
\hline $53^{\mathrm{a}}$ & 1809 & 3916 & 45 & 122 & 94 & 23 & 60 & 170 & 11 & 8 \\
$53^{\mathrm{b}}$ & 9175 & 4633 & 17 & 194 & 38 & 26 & 79 & 408 & 14 & 12 \\
54 & 1927 & 2772 & 11 & 69 & 16 & 13 & 78 & 84 & 11 & 8 \\
60 & 987 & 2702 & 20 & 92 & 17 & 12 & 55 & 98 & 13 & 8
\end{tabular}

\footnotetext{
${ }^{\mathrm{a}}$ Hole 53.0-volcanic ash.

${ }^{b}$ Holes 53.1 and 53.2-volcanic ash with clay.
}

Manganese occurs in small amounts in the ash, but titanium is as abundant as in some of the continentallyderived brown clays; Site 53, particularly, has a higher concentration of titanium. The source of the volcanic ash in the Philippine Sea and Mariana Trench is presumed to be the andesitic volcanoes of the Mariana Island Arc system. Presumably, volcanic ash derived from more basaltic volcanoes would contain much higher amounts of titanium, chromium and nickel.

\section{Alkaline Elements}

Compared with brown clays sodium and potassium are only slightly lower, lithium and rubidium are much lower, and cesium present in about the same amount in the volcanic ash.
TABLE 8

Alkaline Elements in Volcanic Ash

\begin{tabular}{lccccc}
\hline Hole & $\mathrm{Na}$ & $\mathrm{K}$ & $\mathrm{Li}$ & $\mathrm{Rb}$ & $\mathrm{Cs}$ \\
\hline 53.0 & 1.06250 & 0.80250 & 0.00283 & 0.00313 & - \\
53.1 & 1.21330 & 0.93428 & 0.00131 & 0.00383 & - \\
54 & 0.91454 & 0.51818 & 0.00141 & 0.00284 & 0.005 \\
60 & 1.14630 & 0.65105 & 0.00151 & 0.00324 & 0.005 \\
\hline
\end{tabular}

Iron, Titanium and Manganese Oxides

A plot of total iron (as $\mathrm{Fe}_{2} \mathrm{O}_{3}$ ) against titanium oxide from Sites 53, 54 and 60 is given as Figure 14. The linear relationship between these two minerals is clearly apparent in each site and particularly so for the Site 60 plots. Titanium oxide generally ranges from 0.3 per cent to 0.9 per cent over a total iron range of about 3 to 10 per cent.

Plots of total iron $\left(\mathrm{Fe}_{2} \mathrm{O}_{3}\right)$ against manganese oxide $(\mathrm{MnO})$ are given as Figure 15. The titanium oxide $\left(\mathrm{TiO}_{2}\right)$ content is mainly in the 0.1 to 0.2 per cent range over values of total iron of 3 to 9 per cent.

\section{PHYSICAL PROPERTIES}

(R. E. B.)

\section{Porosity}

Porosities of nannofossil chalk oozes vary systematically with depth, while variations of other sediment types were not closely defined. All of these porosity and wetbulk density data were measured from disturbed sediment samples, thus they do not accurately represent in situ values. (See the discussion about sediment disturbance and porosity in the method section in the appendix)

Brown clay, diatom ooze, radiolarian ooze, foraminiferal-nannofossil chalk ooze, and foraminiferal chalk ooze either were not recovered in enough cores or were too disturbed to determine if their porosities varied systematically with depth. Quaternary to Jurassic brown clays 0 to 127 meters had porosities about 65 to 90 . Quaternary to Pleistocene diatom oozes recovered from 0 to 56 meters below the sediment surface had porosities about 80 to 90 per cent, and Pleistocene and Oligocene radiolarian rich sediments from 0 to 335 meters had irregular porosities within 50 to 85 per cent. Foraminiferal-nannofossil chalk ooze and foraminiferalchalk ooze from 0 to 241 meters below the sediment surface, of Pleistocene to Oligocene and Jurassic age, had typical porosities with 50 to 75 per cent regardless of age or depth. 


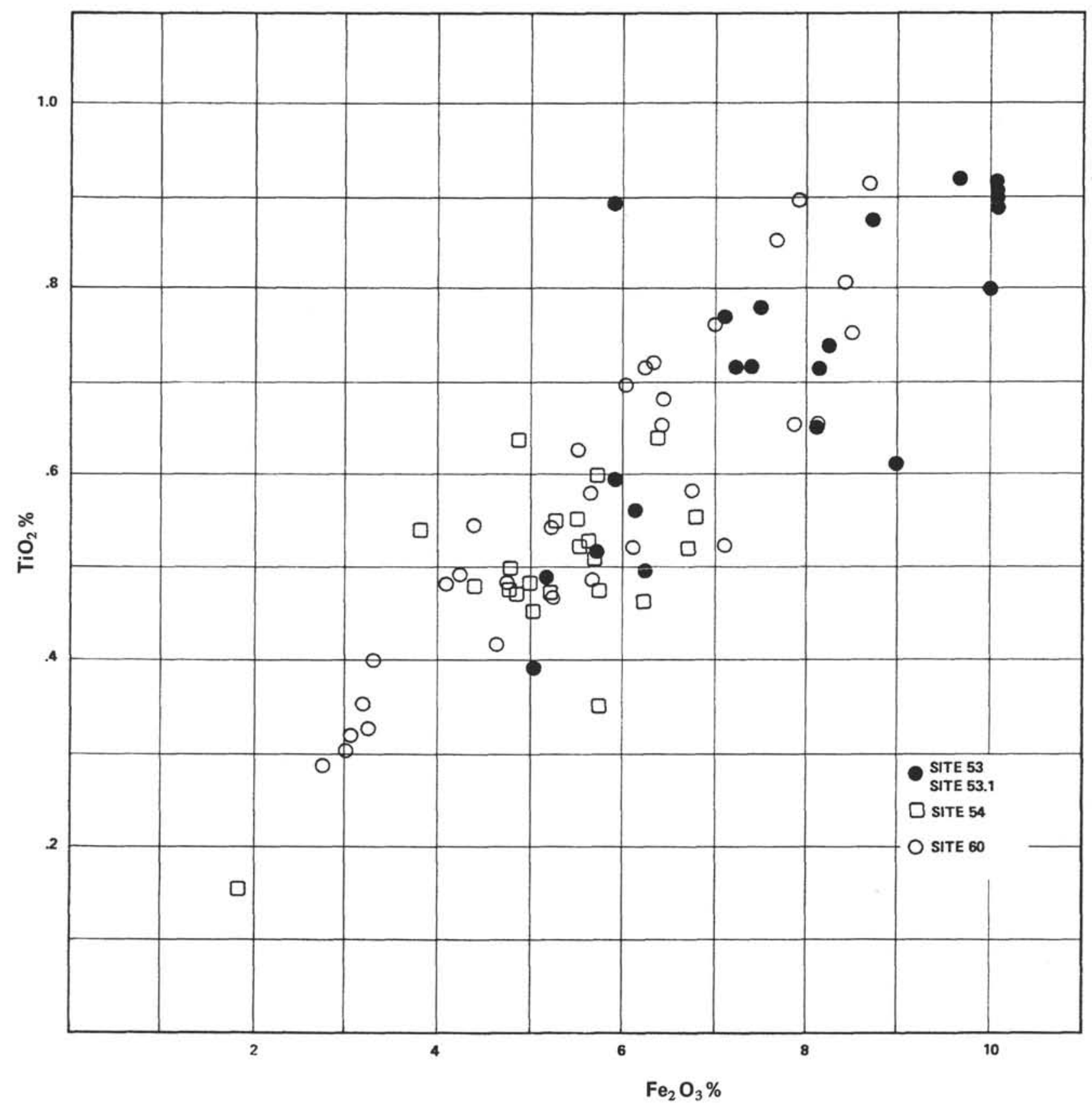

Figure 14. Plots of total iron against $\mathrm{TiO}_{2}$ in volcanic ash.

Porosities of volcanic ash does not appear to be related to depth or age. Pleistocene to Jurassic ash from the sediment surface show porosities of 66 to 75 per cent, while porosities in Miocene ash from 21 to 266 meters tend to vary irregularly and have typical values of 63 to 50 per cent. These porosities are related compaction, particle size and, of course, they were affected by coring disturbance.
Nannofossil chalk ooze tended to decrease ii. porosities with increasing depth and age. In general, porosities greater than about 60 per cent tend to be Pleistocene through Miocene in age, while porosities lower than about 60 per cent typically occur in Oligocene and older sediments. These variations do not specifically appear to be related to depth, although the 60 to 65 meter interval corresponds to the Miocene-Eocene 


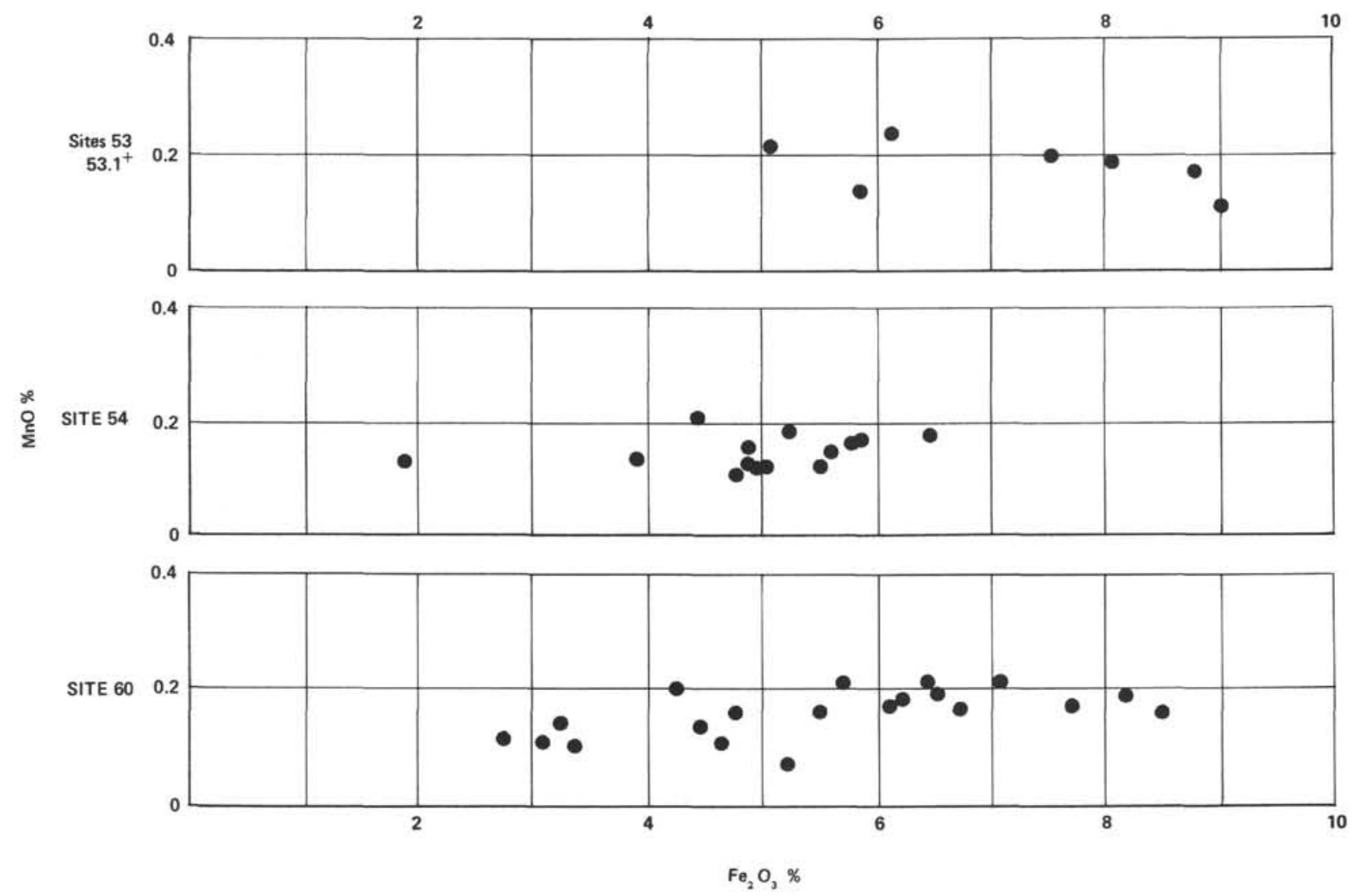

Figure 15. Plots of $\mathrm{Fe}_{2} \mathrm{O}_{3}$ against $\mathrm{MnO}$ of volcanic ash.

unconformity at Hole 47.2 and the Miocene-Cretaceous unconformity at Hole 48.2.

In general, porosity variations are affected by grain size, compaction, volcanic ash and clay mineral contents, and coring disturbance. For example, at Site 47 the Pleistocene through Miocene sediments are finer grained than the Eocene sediments below.

For a more detailed discussion see the individual province summaries that follow.

\section{Pacific Ocean Basin}

Quaternary through Cretaceous diatom and radiolarian oozes, volcanic ash, zeolitic clay, and marls were cored between 0 and 127 meters in the Pacific Basin Province (Sites 45, 46, 51, 52 and 59). In general, porosity did not systematically vary with the depth of recovery or age, possibly a result of sediment disturbance during the coring operations.

\section{Shatsky Rise}

The Shatsky Rise was cored at Sites 47 through 50 . Sediments recovered were fossil oozes, pelagic clays and volcanic ash ranging in age from Pleistocene to
Jurassic. Brown clays and foraminiferal-nannofossil chalk ooze were only recovered at the surface at the Shatsky Rise. Their ages ranged from Pleistocene to Jurassic, yet a systematic porosity variation with age was not evident.

Nannofossil chalk oozes were recovered from 6 to 137 meters below the sediment surface; in general, porosity variations appear to be related to depth of recovery and age, although there are exceptions. Sediments collected between 6 and 70 meters have porosities between 60 and 75 per cent with typical porosities about 60 per cent or slightly higher. These sediments are typically Pleistocene to Miocene in age, although some Cretaceous-Jurassic ooze also have high porosity. Nannofossil chalk ooze from within 65 to 137 meters typically show lower porosities -40 to 63 per cent-with the more common values about 50 to 60 per cent. Here the age ranges from Eocene-Paleocene to Cretaceous. Some of the above variations were caused by grain size differences and coring disturbance, thus not necessarily representative of in situ conditions.

Nannofossil chalk ooze at Holes 47.2 and 48.2 was cored across the Upper Miocene-Eocene unconformity and Miocene-Cretaceous unconformity, respectively. 
At Hole 47.2 the Miocene nannofossil chalk ooze had porosities of about 60 per cent compared to 54 per cent in the Eocene ooze. The Eocene sediments were typically coarser than the Miocene sediments above them. At Hole 48.2, the greater porosities occurred in the Pliocene and Miocene marly oozes and the lower porosities occurred in the Cretaceous sediments.

\section{Caroline Ridge}

The Caroline Ridge area was cored at Sites 55 through 58 . The sediments recovered at these sites were mainly biogenic oozes with volcanic ash. Porosity variations were related to grain size distribution and compaction.

In general, the porosities appear to decrease with increasing depth and age, but the data are not conclusive. Nannofossil chalk ooze of Pleistocene through Miocene age recovered from 0 to 113 meters show porosities of 80 to 56 per cent, while Oligocene ooze from 103 to 335 meters range within 40 to 60 per cent, with 55 per cent being typical. Cores with greater porosities were obviously disturbed in drilling.

Foraminiferal-nannofossil chalk ooze, foraminiferal chalk ooze, Radiolaria-rich sediment and diatom ooze do not systematically vary with age or depth. Diatom ooze was recovered at the sediment surface, but was disturbed.

\section{Philippine Sea}

In the Philippine Sea province (Sites 53, 54 and 60), porosity and wet-bulk denisty measurements were continuously measured in the sediments cored in plastic liners down to a maximum depth of 270 meters. Brown clay, radiolarian ooze, nannofossil chalk ooze, but predominantly volcanic ash of Miocene to Oligocene (?) age were recovered.

Brown clays, zeolitic clays, and ashey radiolarian oozes recovered within 0 to 22 meters below the sediment surface had porosities of 65 to 84 per cent. Some of the lower porosities were associated with abundant volcanic ash. Nannofossil chalk ooze was recovered from the sediment depths of 52 to 70 meters and 120 to 131 meters, and had typical porosities of 60 and 55 per cent, respectively. At different sites, volcanic ash was also recovered at different depths: 21 to 110 meters, 85 to 266 meters, and 120 to 131 meters; and, porosities generally had an irregular variation from 63 to 50 per cent.

In general, porosity appears to decrease with increasing depth. However, this variation is not completely the result of compaction. In part, it is related to the stratigraphic position of certain types of sediments that normally have high porosities in an unconsolidated state, such as clays and radiolarian ooze, which are located at the top of the section. There is a hint of compaction with depth but the evidence is not compelling. Some of these variations may have been the result of coring disturbance and grain size variations.

\section{Natural Gamma Radiation}

Natural gamma radiation emitted from the sediments recovered from all the provinces related mainly to lithology, but in some areas it related to age. In general, high radiation is emitted from clays, zeolites, feldspars, volcanic ash and manganese nodules. Young surface sediments in some areas emit high radiation which could not be overtly associated with the mineral content of the sediments.

Quaternary to Jurassic brown ("red") clays and brown zeolitic clay and Pliocene to Oligocene volcanic ash emit gamma counts of 100 to 2600 counts/7.6-centimeter core segment/1.25 minutes. Typical counts are within 400 to 1500 . Although the brown clay and volcanic ash show similar radiation ranges, the porosities of the ashes are typically lower. It appears that for a given weight of particulate material, the clays would probably have the greater radiation. Radiation variations, of course, depended on dilution with other particulate matter.

Pleistocene to Cretaceous carbonate sediments consisting of nannofossils or foraminifera have typical low radiation within 50 to 400 counts/7.6-centimeter core segment/ 1.25 minutes. Of course, radiation fluctuations depend on the amount of clay, zeolite or volcanic ash present. Young carbonates of Quaternary to Pleistocene age in some areas yield high counts of 1000 to 2200 , respectively, for nannofossil and foraminiferal-nannofossil oozes. These occurred in the Shatsky Rise and Caroline Ridge areas.

Siliceous ooze consisting of radiolarians or diatoms emit natural gamma counts which tend to be intermediate or high. Quaternary and Pleistocene Ethmodiscus rex diatom oozes yield counts of 7100 , and 1500 to 5200 counts, respectively. Other Pleistocene diatom oozes show typical counts within 900 to 1800 . Where manganese nodules occur mixed with radiolarians and diatoms gamma counts of about 3300 are emitted. Other Oligocene to Pleistocene radiolarian oozes or radiolarianrich sediments given counts of 50 to 500 while the Radiolaria-diatom volcanic silt and sand range up to 1900.

The high gamma counts emitted from Quaternary Pleistocene surface sediments consisting of Ethmodiscus rex ooze, diatom ooze, radiolarian-diatom oozes, and foraminiferal-nannofossil oozes, could not be explained by a cursory visual examination of the sediments. These emissions may have been from a particular type of claylike mineral with associated ions, independent radioactive minerals, ions in the interstitial water, or volcanic 
ash. A distinct mineralogy was not obvious. It is possible that radioactive material may have been concentrated by the foraminifera, diatoms and radiolarians. The decrease of gamma radiation with depth may be a function of radioactive disintegration, variation of detrital, chemical or mineral sources, sedimentation or accumulation rate changes, or different paleobottom waters. It is also possible that the exponential decrease may be caused by coring operations which may have dragged the upper sediments down the coring tube.

\section{Pacific Ocean Basin}

The Pacific Ocean Basin sediments cored at Sites 45, $46,51,52$ and 59 included Quaternary through Cretaceous diatom and radiolarian oozes, zeolitic clays, and marl. Most of these sediments contained volcanic ash and were recovered from 0 to 125 meters below the sediment surface. In general, Quaternary-Pleistocene sediments typically emit higher gamma radiation, which varies irregularly (500 to 2000 counts) with depth, showing a tendency to be low in some Miocene sediments. Natural gamma radiation counts from the lower Tertiary and Cretaceous sediments tend to be almost the same as the upper Tertiary, but the sediments near the Cretaceous-Tertiary contact at Site 52 yielded an amount of 2700 counts. Except for the unaccounted burst of radiation from the Quaternary sediment, the radiation appeared to be generated mainly from the clays, zeolites and volcanic ash.

Natural gamma radiation of sediment recovered from the Pacific Ocean Basin does not appear to deviate systematically with age or depth. Certain lithologies distinguish themselves by different gamma counts. Quaternary diatom ooze (Ethmodiscus) has an extremely high count of 7100 counts/7.6-centimeter core segment/1.25 minutes, while Pleistocene diatom and radiolarian volcanic sands and silts emit lower gamma counts-about 900 with a high of 1900 . Miocene marly radiolarian ooze emit about 400 counts. The Quaternary-Cretaceous brown clays which predominate in this province yield gamma counts form 400 to 2600 . Volcanic ashes show counts of 400 to 1950 (?).

\section{Shatsky Rise}

Natural gamma radiation at the Shatsky Rise area, Sites 47 through 50 , ranges from 100 to 3300 counts/ 7.6-centimeter core segment/1.25 minutes. The sediments recovered were foraminifera and nannofossil chalk oozes, pelagic clays, manganese nodules and volcanic ash, ranging in age from Pleistocene to Jurassic.

A composite stratigraphic section at the Shatsky Rise follows. Pleistocene foraminiferal-nannofossil chalk ooze and brown clay with volcanic glass and zeolites show average natural gamma emissions of about 1200 counts/7.6-centimeter core segment/1.25 minutes, while Pleistocene nannofossil chalk oozes average 700 .
A high count of 3300 is emitted from Pleistocene manganese nodules in diatom-radiolarian ooze. PlioceneMiocene marly nannofossil chalk oozes with volcanic glass average lower counts of about 300 , yet there is an abrupt decrease from 300 to 100 counts across the Miocene-Eocene unconformity which is apparently related to a decrease in volcanic glass. The EocenePaleocene and Cretaceous nannofossil chalk oozes average about 100 counts. Jurassic brown zeolitic clays average about 1300 and nannofossil chalk oozes average 300 to 1000 counts with a single high of 3100 .

High natural gamma radiation typically varies with the percentages of volcanic ash, clay, and zeolite in the fossil oozes. Explanations for such high radiation counts at the top of Holes 47.0 and 41.1 are not apparent from the core description (see discussion at beginning of summary).

\section{Caroline Ridge}

The Caroline Ridge province at Sites 55, 56, 57 and 58 yielded mainly fossil oozes of diatoms, nannofossils, foraminifera, radiolarians, sponge spicules, and also volcanic ash. These sediments were recovered between the sediment surface and 335 meters.

Gamma radiation is high at the surface, but decreased "exponentially" immediately below the surface. Below the surface, low radiation is characteristic and relatively constant with increasing depth except where volcanic ash emits higher gamma counts.

Surface sediments of Pleistocene Ethmodiscus ooze show the highest counts in the Caroline Ridge Province with natural gamma radiation ranging from 1500 to 5200 . Other surface sediments of pale brown nannofossil-foraminiferal chalk ooze and nannofossil chalk oozes have high counts of 2200 and 1000 , respectively. Pliocene nannofossil chalk ooze and foraminiferalnannofossil chalk ooze emit gamma counts of about 100. Miocene and some Oligocene nannofossil chalk ooze, foraminiferal-nannofossil chalk ooze, and radiolarian-nannofossil chalk ooze average 50 counts. Some of the Oligocene nannofossil-foraminiferal chalk ooze, nannofossil-radiolarian-sponge spicule ooze and nannofossil chalk ooze, all with volcanic ash or glass, show slightly higher averages of 150 counts. The underlying basalt, probably Oligocene, yields a natural gamma radiation of 350 counts.

\section{Philippine Sea}

The Philippine Sea province includes Sites 53, 54 and 60 where predominately volcanic ash was recovered. In general, natural gamma radiation does not vary systematically with depth. The small variation between cores is probably caused by the relative amounts of volcanic glass and clay in these ash beds. These samples were disturbed. 
Natural gamma radiation emitted from the Middle Miocene brown clays, siliceous oozes, nannofossil ooze and ash ranges from zero to 2350 counts/7.6-centimeter core segment/1.25 minutes, and averaged 500. In general, the differing lithologies ( 0 to 200 meters) of the Miocene to Oligocene (?) "red" zeolite clay, radiolarian silt, volcanic ash, chalk oozes, limestones, and hard tuffs do not appear to emit distinguishing signatures. The highest counts of 900 and 2350 are emitted from Miocene volcanic sand. The lowest radiation is emitted from the Miocene or Oligocene (?) limestone and volcanic rocks recovered from depth of 195 to 200.6 meters.

\section{Sound Velocity}

Sound velocities through sediments from all areas irregularly vary with increasing depth, and are related to porosity as reported by previous investigators. Sound velocity at some sites increased irregularly with increasing depths. From the disturbed sediments recovered (see methods appendix for a discussion of disturbance and sound velocity), velocities relate more to lithology and depth than to the specific age of the sediment. In general, "red" clays, foraminiferal and diatom oozes transmit sound slowly while radiolarian oozes, nannofossil chalk oozes and some ash tend to have intermediate velocities. Volcanic sand and ash tend to have the highest sediment velocities. Of course, variations relate to various combinations of particulate matter.

Pleistocene to Jurassic brown ("red") clays and brown zeolitic clays were recovered from 0 to 27 meters beneath the sediment surface. Velocities range from 1.47 to $1.67 \mathrm{~km} / \mathrm{sec}$ with typical values within 1.51 to 1.55 $\mathrm{km} / \mathrm{sec}$. These low velocities are related to the high porosity of the clay.

Siliceous oozes consisted predominately of diatoms and radiolarians. Quaternary and Pleistocene diatom oozes, recovered from 0 to 32 meters below the sediment surface, propagate sound at 1.48 to $1.56 \mathrm{~km} / \mathrm{sec}$. Radiolarian oozes ranging in age from Pleistocene to Oligocene were recovered from 0 to 146 meters. Velocities range from 1.46 to $1.65 \mathrm{~km} / \mathrm{sec}$, and possibly increased with increasing depth and age. Typical velocities are within 1.51 to $1.57 \mathrm{~km} / \mathrm{sec}$. In general, radiolarian oozes tend to have greater velocities than the diatom ooze, but the sampling population is too small to be certain. Velocity variations occur when the sediment contains various amounts of carbonates, clay and volcanic ash.

Carbonate sediments consist predominately of nannofossils and foraminifera, although some nonskeletal and megafossil carbonates were recovered. Pleistocene to Jurassic nannofossil chalk ooze from 0 to 320 meters has velocities ranging from 1.46 to $1.91 \mathrm{~km} / \mathrm{sec}$ and, in general, velocity irregularly increases with increased age and depth. Typical velocities are 1.52 to $1.58 \mathrm{~km} /$ sec. Foraminiferal-nannofossil chalk ooze of Pleistocene, Miocene and Oligocene age were recovered from sediment depths of 0 to 300 meters. Velocities vary from 1.48 to $1.96 \mathrm{~km} / \mathrm{sec}$. Although, typical velocities (1.48 to $1.60 \mathrm{~km} / \mathrm{sec}$ ) irregularly increase with increasing depth-velocities of the young and old and shallow and deep sediment are about the same (1.70 to 1.74 $\mathrm{km} / \mathrm{sec}$ ). Nonskeletal carbonates and shell fragment carbonates were recovered at the surface ( 0 to 9 meters) in the Caroline Ridge area. The nonskeletal silt has velocities of 1.51 to $1.64 \mathrm{~km} / \mathrm{sec}$ while the shell fragments transmit sound at $1.78 \mathrm{~km} / \mathrm{sec}$. This sediment has low porosities.

Miocene to Oligocene volcanic ash, mainly from the Philippine Sea area (?) was encountered at depths from 0 to 266 meters beneath the sediment surface. Velocities are typically 1.58 to $1.95 \mathrm{~km} / \mathrm{sec}$ and, in general, irregularly increase with increasing depth. The highest velocity is $2.3 \mathrm{~km} / \mathrm{sec}$. These variations are in part related to grain size and porosity variations. The presence of volcanic ash in clays and oozes tends to give them higher velocities.

Some consolidated limestone and tuff were recovered along with basalt cores. The limestone and tuff transmit sound within 3.2 to $4.3 \mathrm{~km} / \mathrm{sec}$. Altered basalt or andesite propagates sound at 5.2 to $5.7 \mathrm{~km} / \mathrm{sec}$, while fresher basalt transmits sound at 5.3 to $6.9 \mathrm{~km} / \mathrm{sec}$. The vitreous fragments cemented by fine-grained volcanic glass transmit sound at $3.7 \mathrm{~km} / \mathrm{sec}$.

\section{Pacific Ocean Basin}

Five sites were drilled into the northwest Pacific basin floor: $45,46,51,52$ and 59 , recovering predominately disturbed "red" clay and siliceous ooze with some ash. Pleistocene to Cretaceous brown clay from 0 to 123 meters below the sediment surface has typical sound velocities of about $1.53 \mathrm{~km} / \mathrm{sec}$, and ranges from 1.47 to $1.67 \mathrm{~km} / \mathrm{sec}$. These clays show varying amounts of ash- and sand-size particles which apparently cause higher velocities. Miocene radiolarian ooze and radiolarian-sponge spicule ooze cored at 89 to 108 meters shows a high velocity of 1.64 and an average of 1.56 $\mathrm{km} / \mathrm{sec}$.

In summary, sound velocity of the brown "red" clay in the northwest Pacific Basin does not appear to deviate systematically with changing age. The higher clay velocities correlate with the general occurrence of ash, pebbles and chert, and the radiolarian or radiolariansponge spicule oozes. A bubble pulse in the airgun records frustrated any attempt to locate reflectors at these depths. 


\section{Shatsky Rise}

Shatsky Rise cores were collected at Sites 47 through 50. Comparison of data between these sites to depth below the sea floor is not straight-forward, as the drill bit spudded in at different parts of the stratigraphic section at different outcrops or sites.

At the Shatsky Rise area, Pleistocene foraminiferalnannofossil chalk ooze, nannofossil chalk ooze, siliceous ooze and zeolitic clay have typical velocities from 1.48 to $1.55 \mathrm{~km} / \mathrm{sec}$ with a maximum velocity of $1.59 \mathrm{~km} /$ sec. The depths of recovery were within 0 to 30 meters. Pliocene-Miocene nannofossil chalk oozes (27 to 64 meters) show similar velocities of about $1.52 \mathrm{~km} / \mathrm{sec}$ (ranging from 1.48 to $1.55 \mathrm{~km} / \mathrm{sec}$ ). Paleocene-Eocene nannofossil chalk oozes ( 65 to 104 meters) yield higher velocities than the younger sediments. Velocities are typically 1.55 and 1.60 with high velocities (1.60 to $1.65 \mathrm{~km} / \mathrm{sec}$ ) occurring at the upper and lower unconformable contacts. Cretaceous nannofossil chalk ooze (59 to 132 meters) has a maximum velocity of 1.70 , but $1.54 \mathrm{~km} / \mathrm{sec}$ is more typical. Jurassic (?)-Cretaceous nannofossil chalk ooze ( 38 to 44 meters) shows a high velocity of 1.58 with a typical value of $1.53 \mathrm{~km} / \mathrm{sec}$.

In summary, the Shatsky Rise sediments exhibit sound velocities more related to lithologic variations rather than age or depth of burial. In general, Cretaceous sediments have lower velocities than Paleocene-Eocene and Jurassic sediments, but slightly greater velocities than the Pleistocene-Miocene sediments.

From a cursory inspection of the airgun records at Site 47 , it appears that reflections were obtained from the depth interval of the Miocene-Eocene unconformity. However, the airgun bubble pulse produced an irregular signal which also gave a return at that same particular zone. Thus, it was impossible to distinguish if this unconformity actually produced a distinct reflection or if that particular feature of the airgun records is an artifact of the profiling system.

\section{Caroline Ridge}

Drilling sites in the Caroline Ridge area were 55, 56, 57 and 58 , where cores were collected to a maximum depth of 330 meters. Nannofossil chalk ooze and foraminiferal-nannofossil chalk predominate at these sites. Sound velocities appear to increase with increasing age and depth. Pleistocene, Pliocene, Miocene and Oligocene nannofossil chalk ooze were recovered from depths of 0 to 9,9 to 26,30 to 113 , and 113 to 321 meters, respectively. These show typical velocities of 1.51 , to $1.55,1.50$ to 1.61 (1.83?), 1.47 to 1.64 , and 1.62 to $1.91 \mathrm{~km} / \mathrm{sec}$. Foraminiferal-nannofossil chalk ooze varies similarly with depth and age. Pleistocene foraminiferal-nannofossil chalk ooze from 0 to 9 meters typically transmit sound at 1.49 to $1.54 \mathrm{~km} / \mathrm{sec}$, with a high of $1.74 \mathrm{~km} / \mathrm{sec}$. Pliocene foraminiferal-nannofossil chalk ooze ( 9 to 26 meters) transmit sound at 1.50 to $1.61 \mathrm{~km} / \mathrm{sec}$. Miocene ooze from 26 to 103,73 to 120 , and 187 to 196 , respectively, show velocities with 1.50 to $1.58,1.54,1.50$ to 1.64 , and 1.59 to $1.63 \mathrm{~km} / \mathrm{sec}$. Oligocene foraminiferal-nannofossil chalk ooze from 113 to 130 meters and 220 to 233 meters have velocities within 1.55 to $1.70 \mathrm{~km} / \mathrm{sec}$ and 1.63 to $1.83 \mathrm{~km} /$ $\mathrm{sec}$, respectively.

Pleistocene skeletal silt consisting of pelecypod-echinoderm fragments from 0 to 9 meters depth show a velocity of $1.78 \mathrm{~km} / \mathrm{sec}$. "Nonskeletal" silt with about 25 per cent nannofossils recovered in the same core yields velocities of 1.51 to $1.64 \mathrm{~km} / \mathrm{sec}$.

In summary, velocity remains typically about $1.55 \mathrm{~km} /$ $\mathrm{sec}$ through Pleistocene-Miocene sediment with a general increase of velocity in the Oligocene series. In the Oligocene, increase in velocity with increasing depth is associated with a corresponding decrease in porosity and penetrability. In addition, the volcanic ash (coarser grain size and denser packing) and calcareous cementation in the Oligocene sediments are responsible in part for the decrease in porosity and a higher rigidity which creates a higher sound velocity. "Basement" is Oligocene basalt which transmitted sound at 5.31 to 6.02 $\mathrm{km} / \mathrm{sec}$.

\section{Philippine Sea}

In the Philippine Sea area, sound velocity measurements were only possible with semi-disturbed cores collected in plastic liners down to a maximum depth of 270 meters at Sites 53, 54 and 60. In general, sediment sound velocities irregularly increased with increasing depth, up to $2.23 \mathrm{~km} / \mathrm{sec}$. Well logs were taken stratigraphically below the laboratory velocity measurements. Sound velocities from these logs range up to $2.9 \mathrm{~km} /$ sec. It appears that the amount of volcanic ash is directly related to higher velocities and higher wet-bulk density.

More specifically, the thin layer of Miocene brown clays over the ash section shows distinctively lower sound velocities (1.53 to $1.60 \mathrm{~km} / \mathrm{sec}$ ) than the underlying ash section ( 1.53 to $2.23 \mathrm{~km} / \mathrm{sec}$ ). Miocene nannofossil chalk ooze transmit sound at about $1.64 \mathrm{~km} / \mathrm{sec}$. The ash section is typically coarser grained than the overlying brown clay and zeolitic clay and nannofossil ooze. The ash, being coarser grained, has a lower porosity and greater rigidity, which is conducive to propagating sound faster.

Sedimentary limestones and tuffs propagate sound at 3.19 to $4.27 \mathrm{~km} / \mathrm{sec}$ near the basement at Site 53.0 . At Site 54, sound velocities through black vitreous volcanic glass fragments in a matrix of fine-grained volcanic glass range from 3.68 and $3.74 \mathrm{~km} / \mathrm{sec}$, while altered basaltic rock have sound velocities ranging from 5.16 to $5.74 \mathrm{~km} / \mathrm{sec}$. 
The basement rock reported by refraction data (Murauchi et al., 1968) has a supposedly thick layer with a velocity of 3 to $4 \mathrm{~km} / \mathrm{sec}$. This velocity could fit three of the rock types which were measured: (1) lithified tuff, (2) lithified limestone, and (3) black volcanic glass breccia. The basalt has higher velocities.

\section{Thermal Conductivity}

Thermal conductivities of siliceous ooze, clay, and ash from all areas tend to have wide variations with increasing depth and age, however, these measurements were from disturbed sediments (see Methods Appendix for a discussion of coring disturbance and thermal conductivity). Conductivities are controlled primarily by porosity (inversely) rather than lithology, depth or age.

Brown ("red") clays and zeolitic clays were recovered from the sediment surface to 123 meters and are of Pleistocene to Cretaceous-Jurassic age. Thermal conductivities in these clays ranges from 1.87 to $2.90 \mathrm{cal} /\left({ }^{\circ} \mathrm{C}\right.$

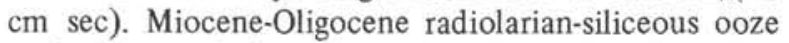
and volcanic ash show thermal conductivity values similar to those of the "red" clay and do not appear to have a systematic variation with depth or age.

Carbonate oozes are predominately nannofossils and foraminifera. Conductivities of Pleistocene to Jurassic nannofossil chalk ooze (recovered from 0 to 325 meters) are 2.22 to $4.40 \times 10^{-3} \mathrm{cal} /\left({ }^{\circ} \mathrm{C} \mathrm{cm} \mathrm{sec}\right)$. Pleistocene to Oligocene foraminiferal-nannofossil chalk ooze conducts heat at 2.14 to $3.62 \times 10^{-3} \mathrm{cal} /\left({ }^{\circ} \mathrm{C} \mathrm{cm} \mathrm{sec}\right)$ with $2.50 \times 10^{-3}$ appearing to be typical. These conductivities irregularly increased in some areas with increasing depth and age and are, of course, primarily related to the porosities (inversely) of these disturbed sediments.

\section{Pacific Ocean Basin}

The Pacific Basin province was sampled at Sites 45,46 , 51,52 and 59 . The sediments consist mainly of disturbed brown clays with volcanic ash and radiolarian ooze of Quaternary to Cretaceous age. Heat conductivity varies slightly and unsystematically between 1.85 to $2.38 \times 10^{-3} \mathrm{cal} /\left({ }^{\circ} \mathrm{C} \mathrm{cm} \mathrm{sec}\right)$.

\section{Shatsky Rise}

The thermal conductivity of predominately nannofossil chalk ooze, cored at the Shatsky Rise (at Sites 47 through 50), ranges from 2.44 to $4.37 \times 10^{-3} \mathrm{cal} /\left({ }^{\circ} \mathrm{C}\right.$ $\mathrm{cm} \mathrm{sec)}$, respectively. These values are generally lower than those of nannofossil chalk ooze.

In general, the thermal conductivities of Shatsky Rise sediments are lower in the Pleistocene-to-Miocene than in the Oligocene-to-Cretaceous nannoplankton chalk ooze. These variations are principally related to the porosity of the samples. When these values are plotted versus depth, they exhibit a similar direct relation to wet-bulk density and sound velocity, and a similar inverse variation to porosity and penetrability.

As was seen in other physical properties measured on sediments from Site 47.2 and 48.2 , there is a contrast between heat conductivity above and below the Miocene-Eocene unconformity and the Miocene-Cretaceous unconformity, respectively. This change is apparently related to the porosity change across this contact.

\section{Caroline Ridge}

The Caroline Ridge area was sampled at Sites 55 through 58 , where predominately nannoplankton chalk ooze and foraminiferal-nannoplankton chalk ooze were recovered from 0 to 325 meters below the sediment surface. Thermal conductivities of these disturbed sediments ranged from 2.16 to $4.40 \times 10^{-3} \mathrm{cal} /\left({ }^{\circ} \mathrm{C} \mathrm{cm} \mathrm{sec}\right)$.

In general, heat conductivity irregularly increases with depth at Site 55.0 but does not appear to vary systematically with lithology, it being more related to the porosity of the samples. Nannofossil chalk ooze of Pliocene, Miocene and Oligocene age, respectively, show conductivity values of $2.86,2.55$ to 3.25 , and 2.35 to $4.40 \times 10^{-3} \mathrm{cal} /\left({ }^{\circ} \mathrm{C} \mathrm{cm} \mathrm{sec}\right)$. Pleistocene skeletal silt conducts heat at 2.78 , while Oligocene nannofossil radiolarian sponge spicule ooze and radiolarian nannoplankton chalk ooze yield high conductivities of 3.68 and $3.10 \times 10^{-3} \mathrm{cal} /\left({ }^{\circ} \mathrm{C} \mathrm{cm} \mathrm{sec}\right)$, respectively.

\section{Philippine Sea}

The Philippine Sea (Sites 53, 54 and 60) yielded semidisturbed sediments at depths between 0 and 291 meters beneath the sea floor. In general, the thermal conductivities of these sediments vary irregularly and do not appear to vary systematically with lithology. Conductivity variations versus depth are inversely similar to water content and questionably similar to the penetrometer averages.

Heat conductivity of unconsolidated Miocene-Oligocene clays, radiolarian silt and ashes cored at Sites 53 and 54 ( 0 to 190 meters) range from 2.00 to $2.71 \times 10^{-3} \mathrm{cal} /$ $\left({ }^{\circ} \mathrm{C} \mathrm{cm} \mathrm{sec}\right)$, averaging $2.26 \times 10^{-3}$. At Site 60 , the Miocene nannoplankton-marl ooze at 51 to 54 meters conducts heat at a rate of 2.50 to 4.13 , with $2.55 \times$ $10^{-3} \mathrm{cal} /\left({ }^{\circ} \mathrm{C} \mathrm{cm} \mathrm{sec}\right)$ appearing to be typical. Miocene ashey sediments at 213 to 291 meters transmit heat at 2.3 to $2.89 \times 10^{-3} \mathrm{cal} /\left({ }^{\circ} \mathrm{C} \mathrm{cm} \mathrm{sec}\right)$.

\section{Penetrability}

In general, the biogenic ooze and clay recovered from all geologic provinces were penetrated much more easily than the volcanic ash. In some areas, clays and radiolarian and diatom oozes were penetrated more easily than nannofossil chalk ooze and ash. Yet, at 
other places the plasticity of the clays appeared to resist penetration more than the unconsolidated nannofossil ooze, which reacted like a "pile of marbles". As all of these cores were disturbed to some extent, these values are not representative of in situ conditions. In general, penetrometer values on these disturbed sediments vary irregularly with increasing depth. Penetration plotted against depth typically had an inverse similarity to water content and a direct relation to sound velocity and thermal conductivity.

\section{Pacific Ocean Basin}

The following penetrometer measurements are stratigraphically summarized for the Pacific Ocean Basin province. In general, penetration appears to decrease with increasing depth. The cores, however, were too disturbed for solid conclusions to be drawn. The presence of ash is associated with less penetration.

Quaternary brown clay with Ethmodiscus ooze (52 to 68 meters) ranges from $70 \times 10^{-1}$ millimeters to complete penetration. Penetration in Pleistocene diatom and radiolarian ooze (23.0t o 27.5 meters) varies within Site 55 to complete penetration. Undifferentiated Tertiary brown clay with ash ( 0 to 55 meters) was penetrated with more difficulty (19 to $200 \times 10^{-1}$ millimeters) with modes of 50 and 100. A slight decrease in penetration occurs in Pliocene clay with ash (28 to 32 meters) where penetrations varied between 33 and $200 \times 10^{-1}$ millimeters, while Miocene zeolitic clay and marly radiolarian ooze show typical modes of 60 and $170 \times 10^{-1}$ millimeters ( 89 to 126 meters). A drilling artifact, consisting of zeolite clay and diatom ooze (114 to 133 meters), was penetrated 37 to $220 \times 10^{-1}$ millimeters. Cretaceous brown clay from 64 to 67 and 121 to 123 meters was penetrated $40 \times 10^{-1}$ millimeters and 30 to $68 \times 10^{-1}$, respectively.

\section{Shatsky Rise}

The Shatsky Rise area includes Sites 47 through 50, at which predominately nannofossil oozes with volcanic ash were recovered between the sediment surface to 137 meters below the sea floor. Some clay and foraminiferal-nannofossil ooze were recovered at the surface. Penetrability at the Shatsky Rise ranges from 39 to complete penetration. Penetration appears to be related more to porosity and grain size than to increasing depth or age. In a very general sense the coarser the sediment, the more easily it is penetrated. Comparison of data between these sites to depth below the sea floor is not straightforward, as the drill bit spudded in at different parts of the stratigraphic section at different outcrops or sites. In addition, there was coring disturbance. Penetrability typically varied directly to wetbulk denisty; and, where porosities were lower than 60 per cent, it varied directly to sound velocity.
At Holes 47.2, 48.2 and 49, the lower penetration values tend to occur in the Pleistocene to Miocene nannofossil ooze with ash and some clay-contrasted to greater penetration in the Eocene-Paleocene and Cretaceous sediments. This may be related to the decreased amount of ash and clay in addition to the coarser and more disturbed nature of the older sediments. At Holes 47.2 and 48.2 the Miocene-Eocene and Miocene-Cretaceous unconformities, respectively, are marked by an increase in penetration below the contact.

\section{Caroline Ridge}

The Caroline Ridge province, cored at Sites 55, 56, 57 and 58 , yielded mainly biogenic oozes combining varying amounts of diatoms, nannofossils, foraminifera, radiolarian, sponge spicules and volcanic ash. Needle penetrations in these disturbed sediments ranged from 0 to complete penetration. Penetration varies with depth, but the range of variations narrows downward ( 0 to 325 meters). In some places, penetration is inversely related to the amount of volcanic ash or clay minerals in the sediment.

In more detail, Pleistocene Ethmodiscus ooze and radiolarian zeolite clay were recovered only at the surface ( 0 to 9 meters). The needle penetrated the diatom ooze $67 \times 10^{-1}$ millimeters and completely penetrated the clay. Nannofossil chalk oozes, however, were recovered from the surface to 220 meters below the sediment surface, ranging from Pleistocene to Oligocene in age. The Pleistocene-Miocene nannofossil oozes from 0 to 113 meters were penetrated within 60 to $270 \times 10^{-1}$ millimeters, while typical penetrations in Oligocene nannoplankton ooze 113 to 220 meters were within 24 and $200 \times 10^{-1}$ millimeters. Yet, Pleistocene marly nannofossil-chalk ooze from 0 to 9 meters was penetrated only 34 to $88 \times 10^{-1}$ millimeters. PleistoceneOligocene foraminiferal-nannofossil chalk ooze, recovered from 0 to 325 meters have penetrability varying typically from $33 \times 10^{-1}$ millimeters to complete penetrations. A minimum of zero was measured in Oligocene from 220 to 233 meters, which contained ash.

\section{Philippine Sea}

The Philippine Sea province was tested at Sites 53, 54 and 60. Sediments are predominately Miocene and Oligocene (?) volcanic ashes and sand with some calcareous and siliceous oozes and clays. At Site 53, core averaged penetrations irregularly decrease from 90 and $110 \times 10^{-1}$ millimeters in Miocene red clays and radiolarian silt (0 to 21 meters), respectively, to about 10 in the Miocene-Oligocene (?) ashes down to a depth of 200 meters. Volcanic ash recovered at Site 54 was typically penetrated from 0 to $80 \times 10^{-1}$ millimeters and at Site 60 penetrometer measurements in nannofossil chalk oozes and volcanic ash span 2 to $90 \times 10^{-1}$ millimeters. 
In general, red clays and radiolarian silt ( 0 to 21 meters) are more easily penetrated than nannofossil ooze and volcanic ash. The amount of penetration varies irregularly with increasing depth and does not appear to be systematically related to depth or age. Penetration plotted against depth shows an inverse similarity to water content, sound velocity and thermal conductivity.

\section{REFERENCES}

Arrhenius, G. O. S., 1963. Pelagic Sediments. In The Sea. M. N. Hill (Ed.). New York (Interscience) 3, 655.

Berger, W. H., 1967. Foraminiferal ooze: solution at depths. Science. 156, 383.

1968. Radiolarian skeletons: solution at depths. Science. 159, 1237.

1970. Biogenous deep-sea sediments: fractionation by deep-sea circulation. Geol. Soc. Am. Bull. 81, 1385.

Bramlette, M. N., 1946. The Monterey Formation of California and the origin of its siliceous rocks. $U$. S. Geol. Surv. Profess. Paper. 212, 1.

Davis, E. F., 1918. The radiolarian cherts of the Franciscan Group. Univ. Calif. Publ., Bull. Dept. Geol. $11(3), 235$

Deer, W. A., Howie, R. A. and Zussman, J., 1963. Framework Silicates of Rock Forming Minerals. London (Longmans, Green \& Co., 1td.), 400.

Ernst, W. G. and Calvert, S. E., 1969. An experimental study of the recrystallization of porcelanite and its bearing on the origin of some bedded cherts: $\mathrm{Am}$. J. Sci. 267A (Schairer Vol.), 114.

Fagan, J. J., 1962. Carboniferous cherts, turbidites, and volcanic rocks in northern Independence Range, Nevada: Bull. Geol. Soc. Am. 73, 595.

Folk, R. L. and Weaver, C. E., 1952. A study of the texture and composition of chert. Am. J. Sci. 250, 498.

Garrison, R. E. and Fischer, A. G., 1969. Deep-water limestones and radiolarites of the Alpine Jurassic. In Depositional Environments in Carbonate Rocks. G. M. Friedman (Ed.). Soc. Econ. Paleontol. Mineral. Spec. Publ. (14), 20.
Goldberg, E. D. and Arrhenius, G. O. S., 1958. Chemistry of Pacific pelagic sediments. Geochim. Cosmochim. Acta. 13, 155.

Grunau, H. R., 1959. Mikrofazies und Schichtung ausgewählter jungmesozoischer, Radiolarit-Führender Sedimentserien der Zentral-Alpen. Intern. Sed. Petrogr. Series. 4, 179.

Honjo, S. and Fischer, A. G., 1965. Paleontological investigation of limestones by electron microscopy. In Handbook of Paleontological Techniques. B. Kummel and D. Raup (Eds.). San Francisco (W. H. Freeman and Co.), 326.

Minoura, N. and Honjo, S., 1969. Experimental study of aragonite-calcite alteration in carbonate lithifications. J. Geol. Soc. Japan. 75 (12).

Morgenstern, M., 1967. Authigenic cementation of scoriaceous deep-sea sediments west of the Society Ridge, South Pacific. Sedimentology. 9, 105.

Ninkovich, D., Opdyke, N., Heezen, B. C. and Foster, J. H., 1966. Earth Plan. Sci. Letters. 1, 476.

Olausson, E., 1960. Description of sedimentary cores from Central and Western Pacific with the adjacent Indonesian Region. Rep. Swedish Deep-Sea Exped. 6, fasc. 5 .

Peterson, M. N. A., 1966. Rates of dissolution in a vertical profile in the Central Pacific. Science. 154, 1542.

Revelle, R., Bramlette, M., Arrhenius, G. O. S., 1955. Pelagic sediments of the Pacific. In Geol. Soc. Am. Spec. Papers. 62, 221.

Rex, R. W. and Goldberg, E. D., 1958. Quartz content of pelagic sediments of the Pacific Ocean. Tellus. $10,153$.

Riedel, W. R., 1959. Siliceous organic remains in pelagic sediments. In Silica in Sediments. H. A. Ireland (Ed.). Soc. Econ. Paleontol. Mineral. Spec. Pub. (7), 80.

Robertson, E. C., 1965. Experimental consolidation of carbonate mud. In Dolomitization and Limestone Diagenesis. Soc. Econ. Paleontol. Mineral. Spec. Pub. L. C. Pray and R. C. Murray (Eds.). (13) 170 (abstract).

Ruddiman, W. R., and Heezen, B. C., 1967. Differential solution of planktonic foraminifera. Deep Sea Res. 14, 801 . 